\title{
Estudo do uso de agregado reciclado de resíduos de construção e demolição em misturas solo-agregado
}

Dissertação apresentada à Escola de Engenharia de São Carlos, Universidade de São Paulo, como parte dos requisitos para a obtenção do título de Mestre em Ciências

- Programa de Pós-graduação em Engenharia de Transportes.

Área de concentração: Infraestrutura de Transportes.

Orientadora: Prof. ${ }^{\mathrm{a}}$ Dr. ${ }^{\mathrm{a}}$ Ana Paula Furlan 
AUTORIZO A REPRODUÇÃO TOTAL OU PARCIAL DESTE TRABALHO, POR QUALQUER MEIO CONVENCIONAL OU ELETRÔNICO, PARA FINS DE ESTUDO E PESQUISA, DESDE QUE CITADA A FONTE.

Ficha catalográfica elaborada pela Biblioteca Prof. Dr. Sérgio Rodrigues Fontes da EESC/USP com os dados inseridos pelo(a) autor(a).

Orioli, Monigleicia Alcalde

Uso de agregado reciclado de resíduos de construção e demolição em misturas solo-agregado / Monigleicia Alcalde Orioli; orientadora Ana Paula Furlan. São Carlos, 2018.

Dissertação (Mestrado) - Programa de Pós-Graduação em Engenharia de Transportes e Área de Concentração em Infraestrutura de Transportes -- Escola de Engenharia de São Carlos da Universidade de São Paulo, 2018.

1. Agregado reciclado misto. 2. Estabilização granulométrica. 3. Solo-agregado. 4. Auto-cimentação. 5. Materiais de pavimentação. I. Título.

Eduardo Graziosi Silva - CRB - 8/8907 


\section{FOLHA DE JULGAMENTO}

Candidata: Engenheira MONIGLEICIA ALCALDE ORIOLI.

Título da dissertação: "Estudo do uso de agregado reciclado de resíduos de construção e demolição em misturas solo-agregado".

Data da defesa: 24/07/2018.

\section{Comissão Julgadora:}

Profa. Dra. Ana Paula Furlan

(Orientadora)

(Escola de Engenharia de São Carlos/EESC)

Profa. Dra. Rosângella dos Santos Motta (Escola Politécnica/EP-USP)

Profa. Dra. Patricia Barboza da Silva

(Universidade Presbiteriana Mackenzie/UPM)
Resultado:
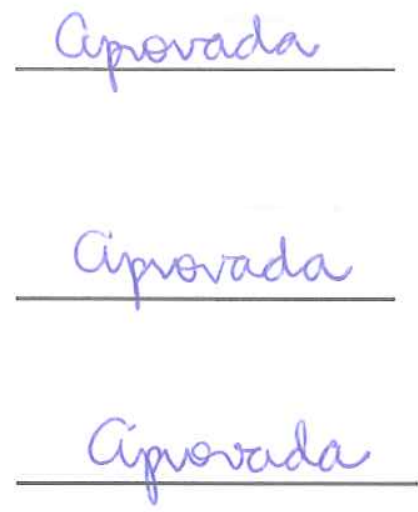

Coordenadora do Programa de Pós-Graduação em Engenharia de Transportes:

Profa. Associada Ana Paula Camargo Larocca

Presidente da Comissão de Pós-Graduação:

Prof. Associado Luís Fernando Costa Alberto 

Aos meus pais, Maria Cristina e Moacir. 


\section{AGRADECIMENTOS}

Aos meus pais Maria Cristina e Moacir, pelo amor incondicional e apoio em todos os momentos da minha vida.

A minha orientadora Prof. a Doutora Ana Paula Furlan, por toda paciência, confiança e dedicação depositadas em mim durante a realização desse trabalho.

A minha professora, orientadora na graduação e amiga Christiane Michiko Passos Okawa, pelos ensinamentos e conselhos para seguir essa trajetória.

Aos Professores do Departamento de Engenharia de Transportes da EESC/USP, pelo conhecimento transmitido durante as aulas.

Aos técnicos do Laboratório de Estradas da EESC/USP, Antônio Carlos Gigante, João Domingos Pereira Filho, Paulo Toyama e ao aluno de iniciação científica André Lapa Tavares pelo apoio na realização dos ensaios.

A todos os amigos e familiares que de alguma forma me deram apoio para superar os momentos de dificuldade e tornaram essa caminhada mais fácil. 
ORIOLI, M. A. (2018) Estudo do uso de agregado reciclado de resíduos de construção e demolição em misturas solo-agregado. Dissertação (Mestrado), Escola de Engenharia de São Carlos, Universidade de São Paulo, São Carlos, 2018.

A construção civil gera impactos ambientais que merecem atenção especial, uma vez que é uma das áreas que mais produz resíduos dentre as atividades econômicas. Os agregados reciclados de resíduos de construção e demolição podem ser utilizados em diversas áreas, apresentando desempenhos mecânico e hidráulico adequados quando comparados aos agregados naturais. Esta pesquisa consiste em estudar a viabilidade o uso de agregado reciclado misto (ARM) e misturas solo-ARM como materiais geotécnicos em camadas de bases e sub-bases de pavimentos. Para isso, foram realizados ensaios de caracterização física e comportamento mecânico. Para comparação, foram estudados também um agregado natural (AN) e uma mistura de solo-AN. Os resultados mostraram que a energia de compactação teve efeito positivo sobre o comportamento do ARM e misturas de solo-ARM. Observou-se ainda que o ARM apresentou ganho de resistência e rigidez devido ao efeito de auto-cimentação. No que se refere à adição de solo, as misturas de solo-ARM apresentaram uma diminuição no valor de CBR em relação a misturas compostas exclusivamente por ARM, contudo houve um aumento nas demais propriedades mecânicas. Com base nos resultados obtidos, pode-se concluir que o ARM e as misturas solo-ARM apresentam características físicas e comportamento mecânico adequados para uso em camadas de base e sub-base de pavimentos urbanos.

Palavras-chave: Agregado reciclado misto, estabilização granulométrica, solo-agregado, auto-cimentação, materiais de pavimentação. 
ORIOLI, M. A. (2018) Study of the use of recycled aggregate of construction and demolition waste in soil-aggregate mixtures. Dissertation (Master's degree), São Carlos School of Engineering, University of São Paulo, São Carlos, 2018.

Civil construction generates environmental impacts that deserve special attention, since it is one of the areas that produces the most waste among economic activities. The recycled aggregates of construction and demolition waste can be used in several areas, presenting adequate mechanical and hydraulic performances when compared to natural aggregates. This research consists of studying the feasibility of using recycled mixed aggregate (RMA) and soilRMA mixtures as geotechnical materials in base and sub-base layers of pavements. For that, tests of physical characterization and mechanical behavior were carried out. For comparison, a natural aggregate (NA) and a soil-NA mixture were also studied. The results showed that the compaction energy had a positive effect on the behavior of RMA and soil-RMA mixtures. It was also observed that the RMA showed strength gain and stiffness due to the self-cementing properties. Concerning soil addition, the soil-RMA mixtures presented a decrease in the CBR value in relation to mixtures exclusively composed by RMA, but there was an increase in the other mechanical properties. Based on the results obtained, it can be concluded that the RMA and the soil-RMA mixtures present physical characteristics and mechanical behavior suitable for the use in base and sub-base layers of urban pavements.

Keywords: Recycled mixed aggregate, physical stabilization, soil-aggregate, selfcementing properties, pavement materials. 
Figura 1: Programa experimental dos ensaios mecânicos complementares..............................35

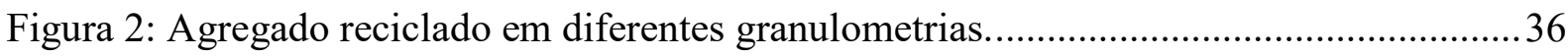

Figura 3: Materiais separados de acordo com a composição. ............................................... 38

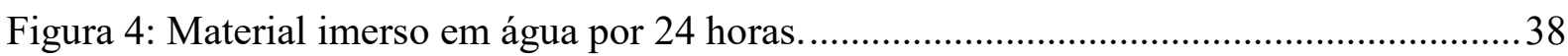

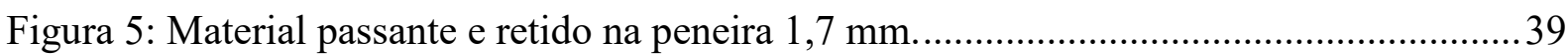

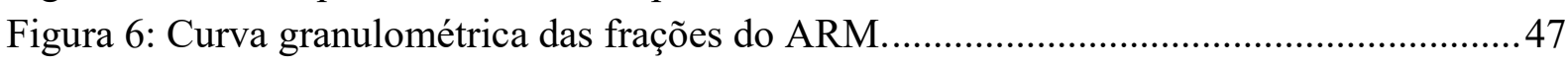

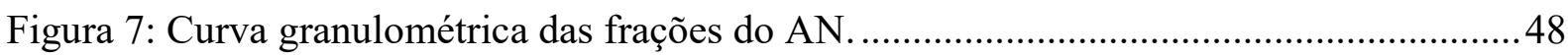

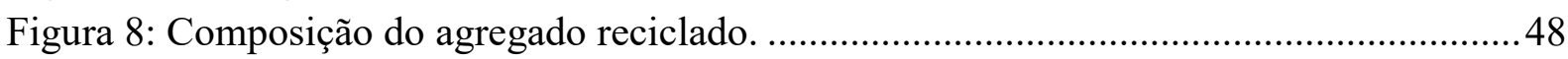

Figura 9: Curva granulométrica da composição do ARM.........................................................50

Figura 10: Curva granulométrica da composição 15\% solo-ARM. ........................................ 51

Figura 11: Curva granulométrica da composição 45\% solo-ARM. ..........................................52

Figura 12: Curva granulométrica da composição solo-AN. ................................................... 53

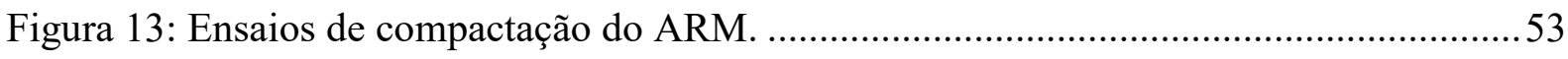

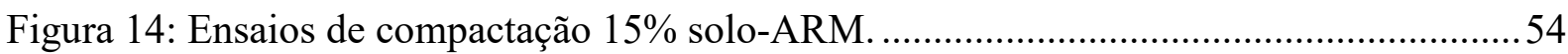

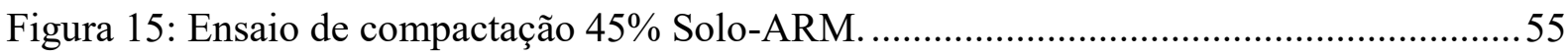

Figura 16: Ensaio de compactação do solo -AN na energia modificada....................................56

Figura 17: Massa específica aparente seca máxima dos materiais. ...........................................57

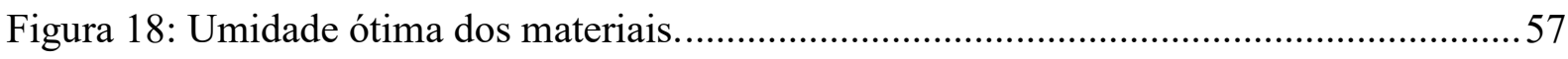

Figura 19: Degradação do ARM na energia intermediária.....................................................59

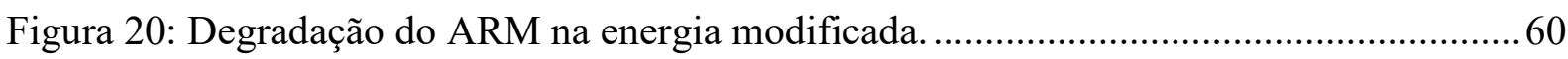

Figura 21: Degradação da mistura 15\% solo-ARM na energia modificada............................. 61

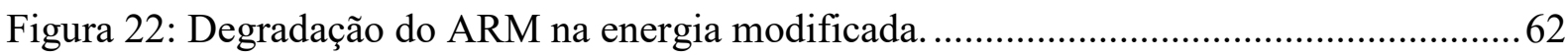

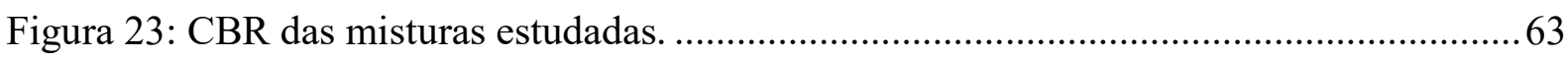

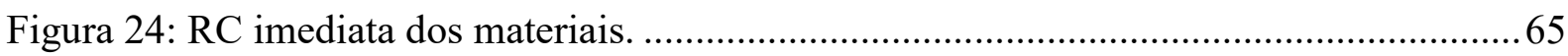

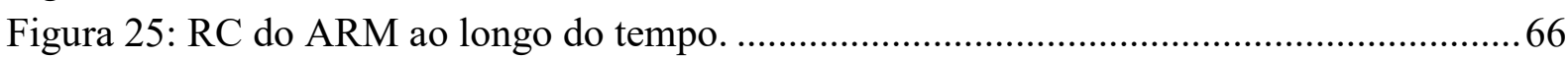

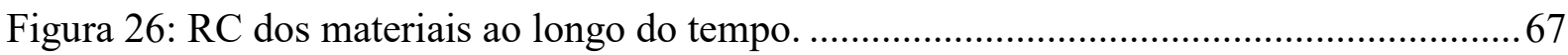

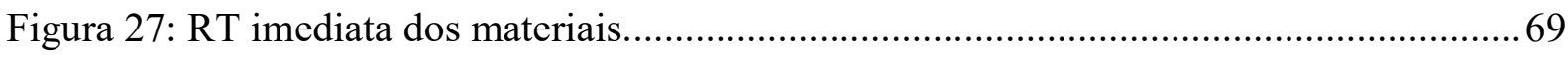

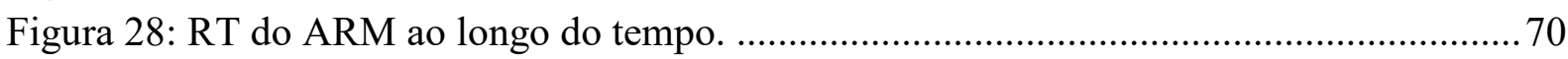

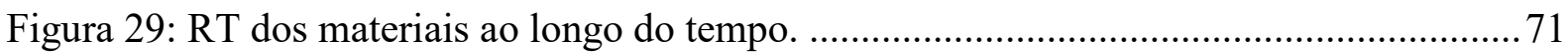

Figura 30: Representação tridimensional do modelo composto para solo-AN e ARM. ..........73

Figura 31:Representação tridimensional do modelo composto para o MR do ARM e 45\% solo-

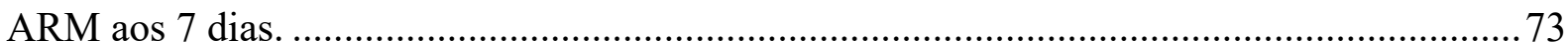

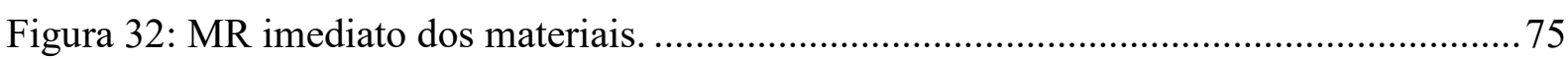

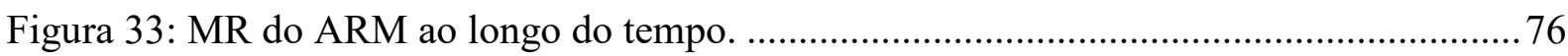

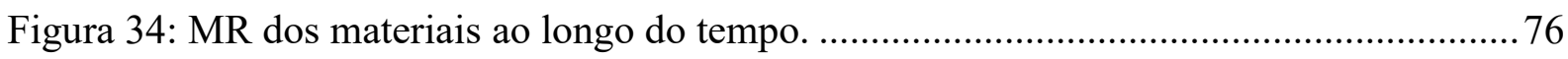


Tabela 1: Características e propriedades desejáveis dos AR (Fonte: ABNT 15115/04) ........ 22

Tabela 2: Faixas granulométricas (Fonte: DNER ES 303/97)............................................ 24

Tabela 3: Resumo dos valores de CBR e Expansão (Fonte: Redivo, 2011)........................... 31

Tabela 4: Pares de tensões aplicados no ensaio de MR. .......................................................... 43

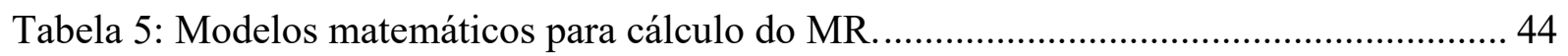

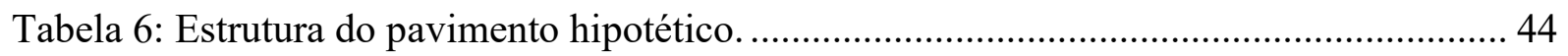

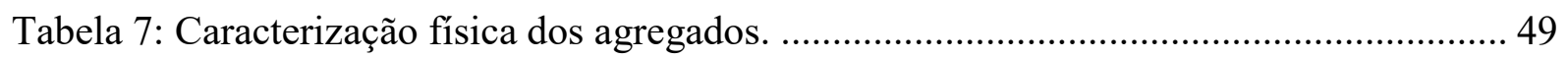

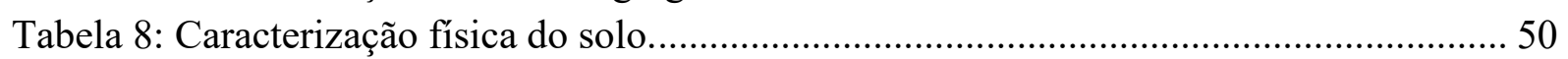

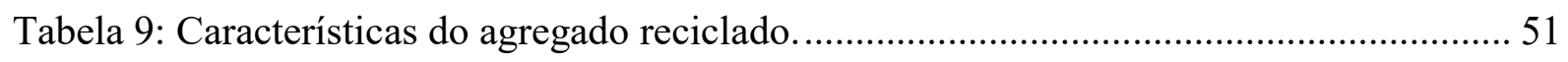

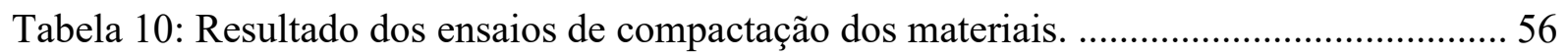

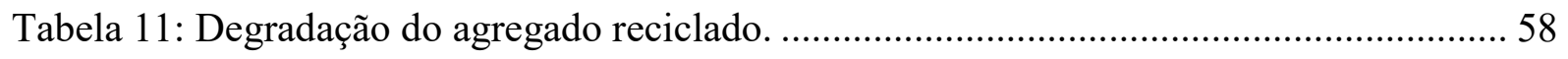

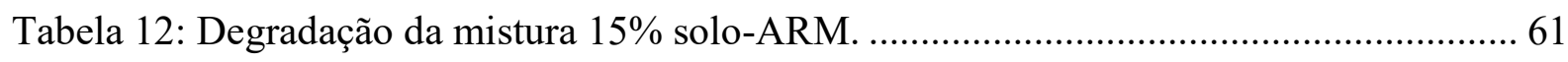

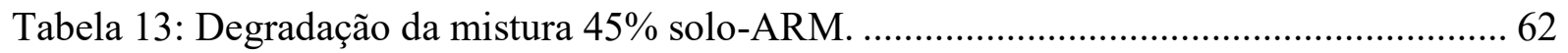

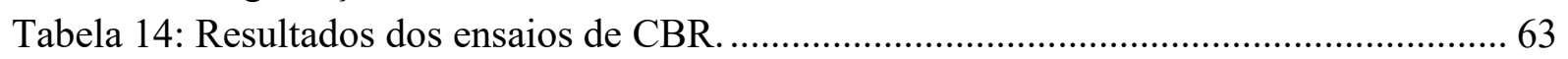

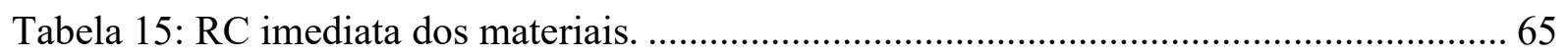

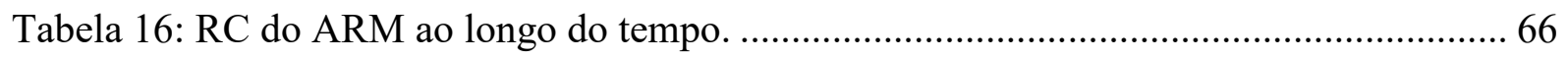

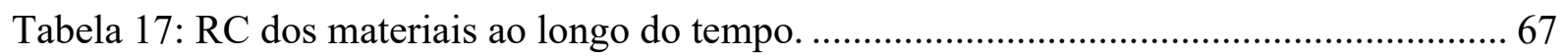

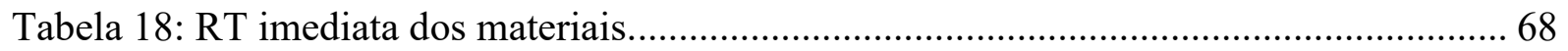

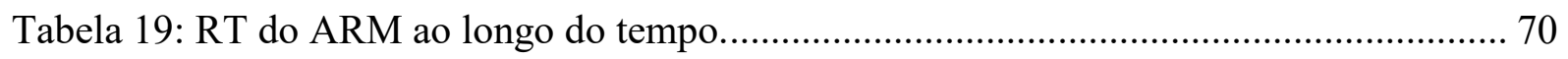

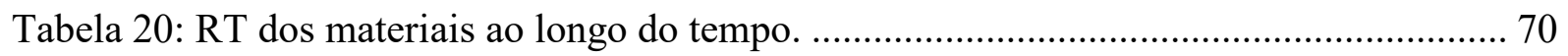

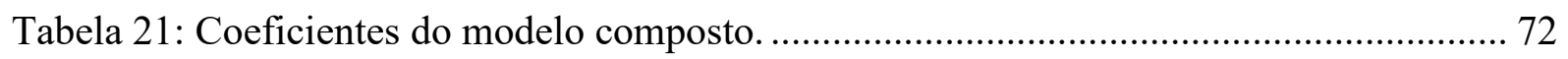

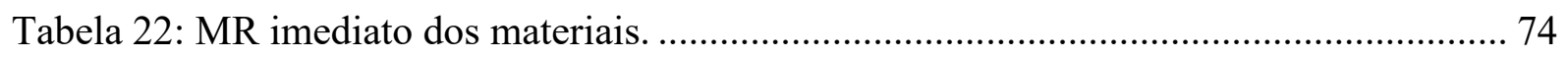

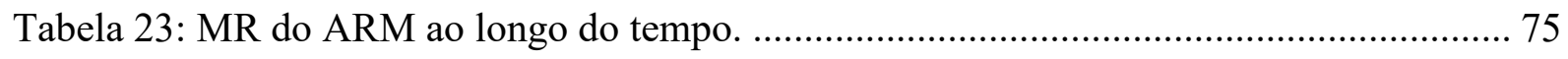

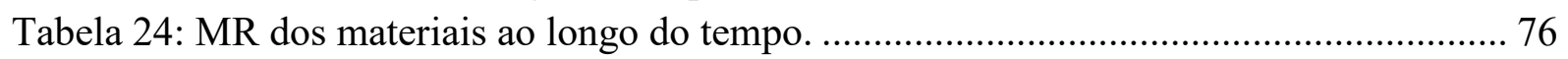




\section{LISTA DE SÍMBOLOS}

$\begin{array}{ll}\mathrm{R}^{2} & \text { Coeficiente de determinação } \\ \mathrm{e}^{\prime} & \text { Caráter laterítico } \\ v & \text { Coeficiente de Poisson } \\ \rho_{\mathrm{dmáx}} & \text { Massa específica seca máxima } \\ \rho_{\mathrm{s}} & \text { Massa específica dos solos } \\ \mathrm{W}_{\text {ótima }} & \text { Umidade ótima } \\ \sigma_{3} & \text { Tensão confinante } \\ \sigma_{\mathrm{d}} & \text { Tensão desvio }\end{array}$


LISTA DE SIGLAS

AASHTO American Association of State Highway Transportation Officials

ABNT Associação Brasileira de Normas Técnicas

ASTM American Society of Testing Materials

CBR Índice de Suporte Califórnia

$\mathrm{CP} \quad$ Corpo de prova

DER Departamento de Estradas de Rodagem

DNIT Departamento Nacional de Infraestrutura de Transportes

GC Grau de compactação

HRB Highway Research Board

LG' Solo argiloso laterítico

LA $\quad$ Solo arenoso laterítico

LL $\quad$ Limite de liquidez

LP Limite de plasticidade

LS Linha de seixos

LVDT Linear Variable Differential Transducers

MCT Miniatura Compactado Tropical

MR Módulo de resiliência

IP Índice de plasticidade

RCS Resistência à compressão simples

RTCD Resistência a tração por compressão diametral 
SUMÁRIO

RESUMO.

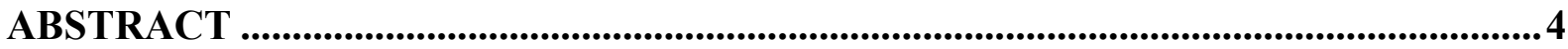

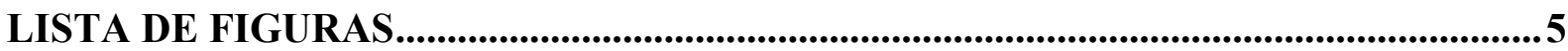

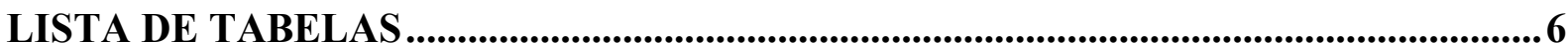

1. INTRODUÇÃO .........................................................................................................................13

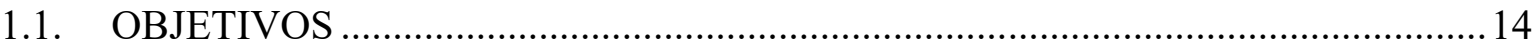

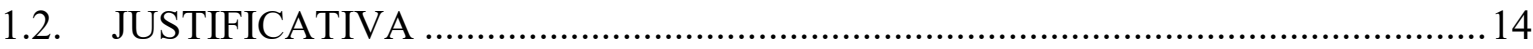

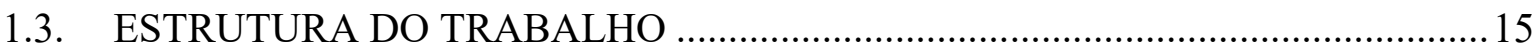

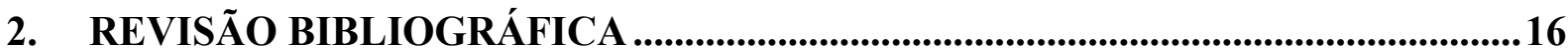

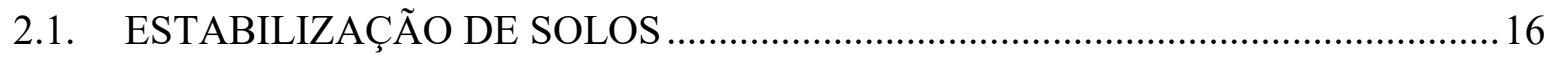

2.2. RESÍDUOS DE CONSTRUÇÃO E DEMOLIÇÃO .................................................17

2.2.1. Composição dos resíduos de construção e demolição e dos agregados

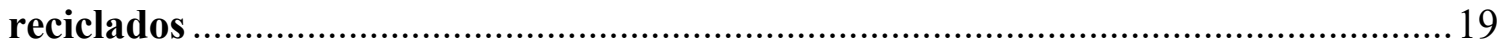

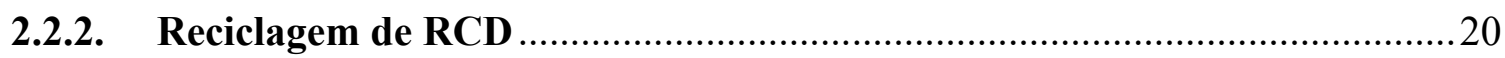

2.2.3. Emprego de agregados reciclados de RCD ……………...............................2 21

2.3. CARACTERIZAÇÃO DO AGREGADO RECICLADO misto ..................................21

2.3.1. Características físicas dos agregados reciclados............................................2

2.3.2. Dosagem de misturas com agregado reciclado …………...............................2

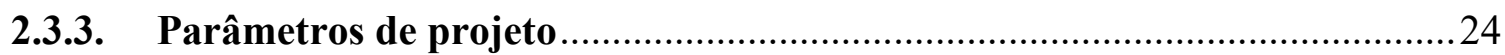

2.3.4. Estudo de propriedades mecânicas dos AR ………………………………....27

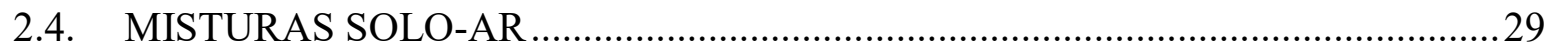

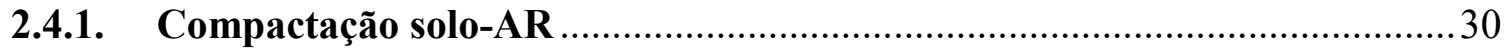

2.4.2. CBR e expansão de misturas solo-AR …………………………………......30

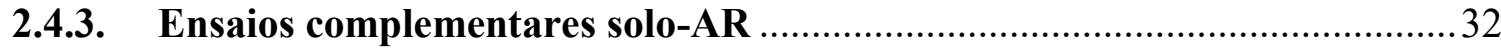

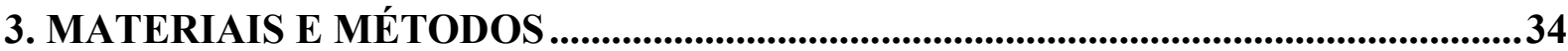

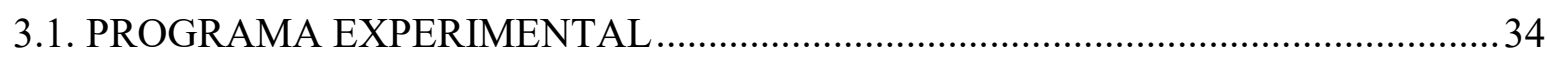

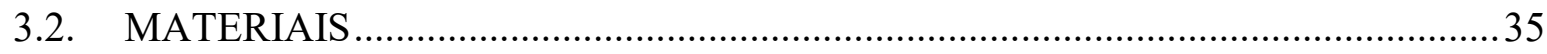

3.2.1. Agregado reciclado misto (ARM) ………………...................................... 35

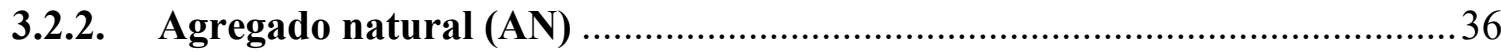

3.2.3. Solo

3.3. CARACTERIZAÇÃO E CLASSIFICAÇÃO DE MATERIAIS ………………….......37

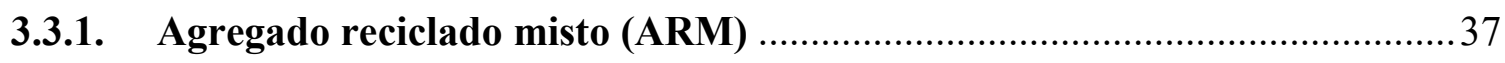

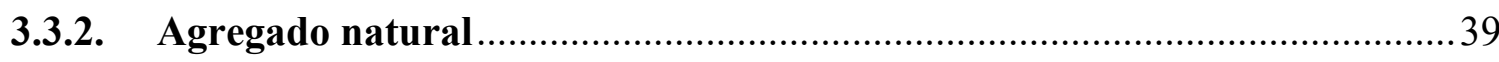


3.3.3. Solo

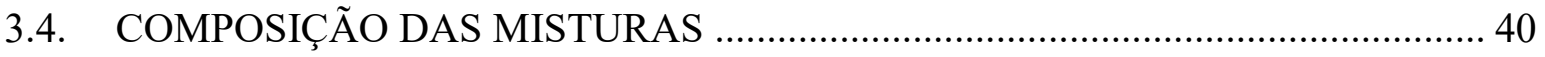

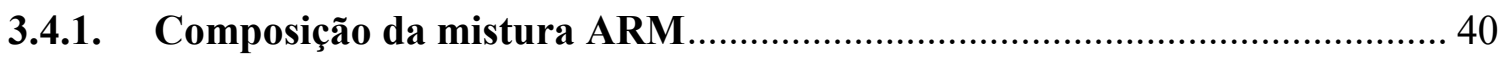

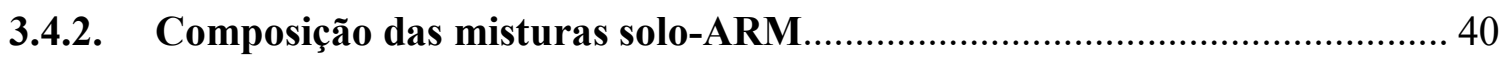

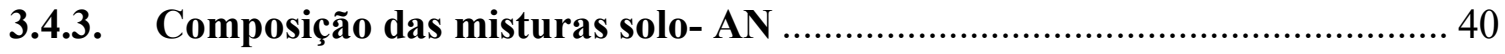

3.5. ENSAIOS DE COMPACTAÇÃO E DEGRADAÇÃO APÓS COMPACTAÇÃO. 40

3.6. ENSAIOS DE COMPORTAMENTO MECÂNICOS DOS MATERIAIS .............. 41

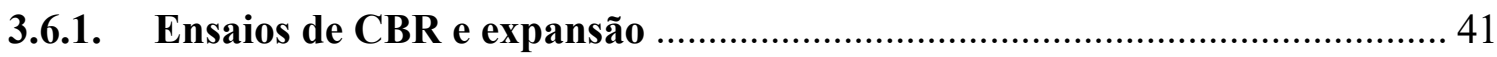

3.6.2. Ensaio de resistência à compressão simples (RCS) .................................... 41

3.6.3. Ensaio de resistência à tração por compressão diametral........................... 42

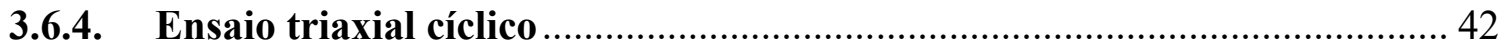

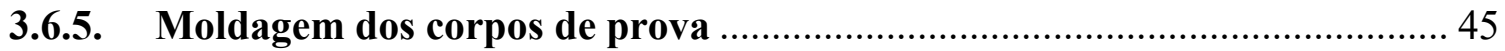

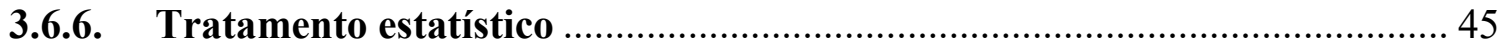

4. APRESENTAÇÃO E DISCUSSÃO DOS RESULTADOS......................................... 47

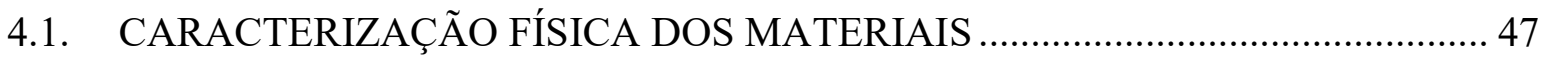

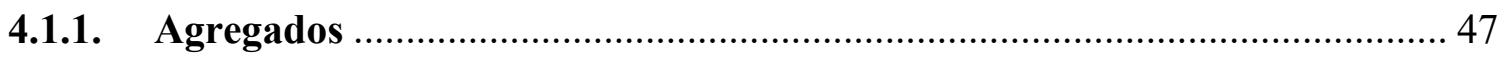

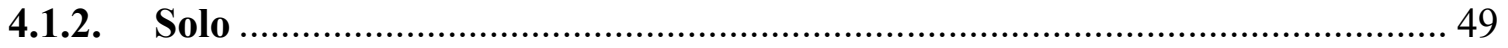

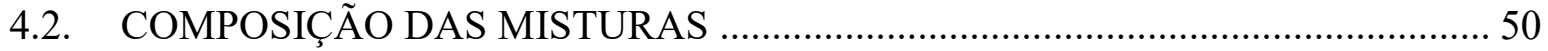

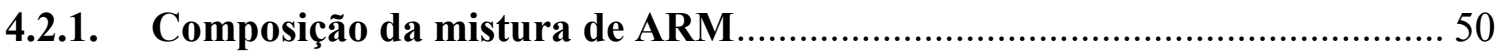

4.2.2. Composição das misturas de solo-ARM...................................................... 51

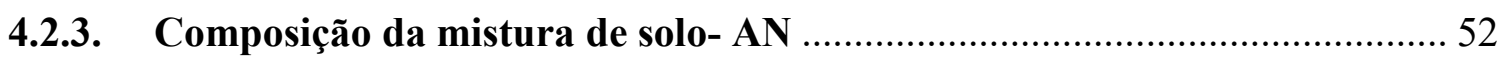

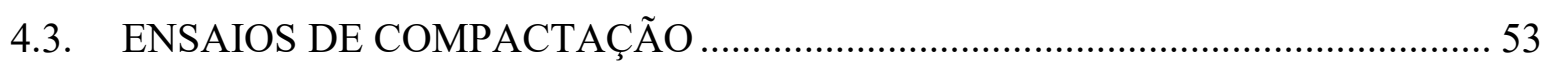

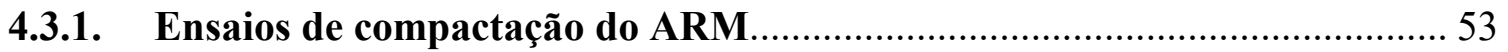

4.3.2. Ensaio de compactação das misturas solo-ARM......................................... 54

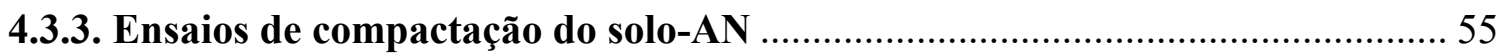

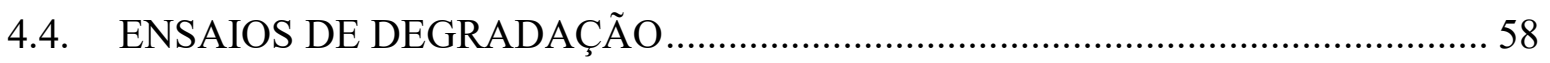

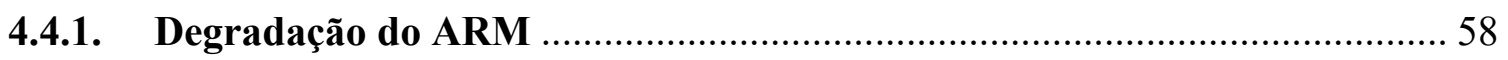

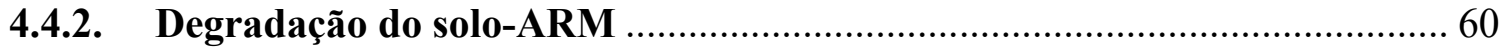

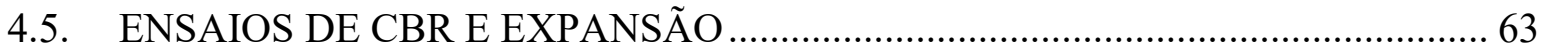

4.6. ENSAIOS DE RESISTÊNCIA A COMPRESSÃO SIMPLES ................................. 64

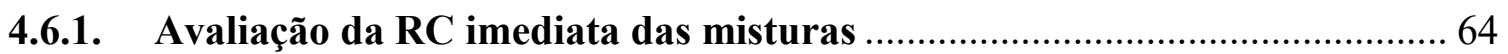

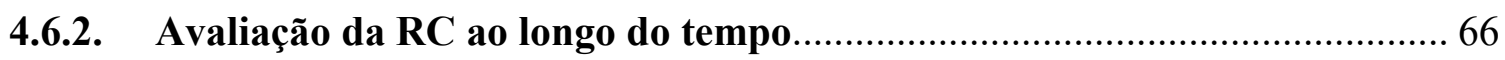

4.7. ENSAIOS DE RESISTÊNCIA A TRAÇÃO POR COMPRESSÃO DIAMETRAL68 


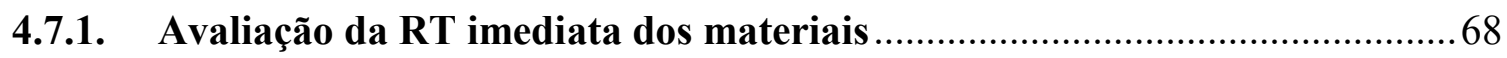

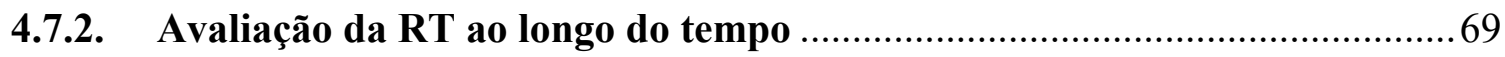

4.8. RESULTADOS DOS ENSAIOS TRIAXIAIS CÍCLICOS ................................... 71

4.8.1. Avaliação do MR imediato dos materiais para pavimento BVT ................ 74

4.8.2. Avaliação do MR ao longo do tempo para pavimento BVT ……................. 75

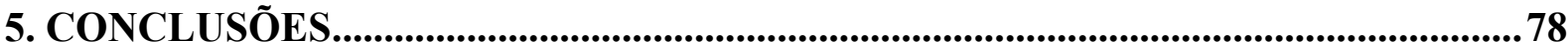

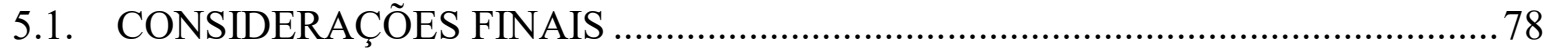

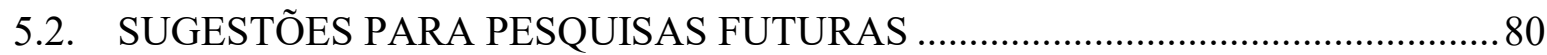

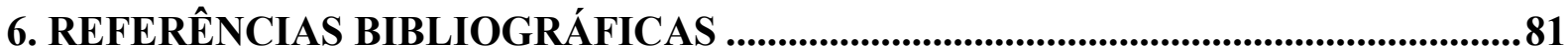

APÊNDICE A- RESISTÊNCIA À COMPRESSÃO............................................................86

APÊNDICE B- RESISTÊNCIA À TRAÇÃO .......................................................................88

APÊNDICE C- MODELOS (MÓDULO DE RESILIÊNCIA) .........................................90 



\section{INTRODUÇÃO}

A estabilização de solos é uma técnica usada em pavimentação com o objetivo de tornar solos e outros materiais aceitáveis para determinado uso. A estabilização granulométrica consiste na combinação entre materiais de diferentes dimensões, onde materiais grossos, finos e solos são misturados em quantidades adequadas, de modo a resultar em um produto de melhores características mecânicas e hidráulicas e maior resistência à erosão. Uma mistura estabilizada granulometricamente comumente utilizada em sub-bases e bases de pavimentos é a mistura de solo-agregado.

O uso de materiais alternativos vem crescendo em pavimentação, principalmente nos últimos anos. Um exemplo que pode ser citado é o uso de agregados reciclados de resíduos sólidos de construção e de demolição utilizados para substituir agregados naturais, que vem mostrando ser uma alternativa sustentável, técnica e economicamente viável. Podem ser empregados em reforço do subleito, base e sub-base de pavimentos desde que atendam às especificações da norma ABNT 15115/2004, sendo utilizados principalmente em vias urbanas, apresentando geralmente desempenhos mecânico e hidráulico adequados.

No entanto, para usá-los, é essencial uma caracterização adequada, pois os agregados reciclados apresentam variedade em sua composição devido a diferentes técnicas, materiais e processamento (POON e CHAN 2006; BARBUDO el al. 2012; BEHERA et al. 2014; CARDOSO et al. 2016).

Apesar dos diversos estudos realizados sobre o uso de agregados reciclados (AR), nas últimas décadas, a quantidade de pesquisas sobre misturas de solo-AR, é pouco expressiva. Devido a seu comportamento coesivo, a adição de solo nas misturas com AR, pode melhorar a trabalhabilidade das misturas e algumas propriedades mecânicas. Assim, este trabalho apresenta um estudo sobre misturas de solo-agregados usando agregado reciclado misto (ARM), tentando avaliar a viabilidade técnica deste tipo de mistura. 


\subsection{OBJETIVOS}

O objetivo geral desta pesquisa é estudar as propriedades físicas e o comportamento mecânico do agregado reciclado misto de resíduos de construção e demolição (ARM) produzido na cidade de São Carlos e de misturas de solo-ARM e avaliar a possibilidade de sua utilização como material em camadas de pavimentos.

Os objetivos específicos dessa pesquisa são:

- Caracterizar o agregado reciclado de São Carlos, com base nos ensaios de granulometria, composição do agregado reciclado, abrasão Los Angeles, absorção e densidade aparente, forma dos grãos e degradação.

- Avaliar o comportamento mecânico do ARM e da mistura solo-ARM por meio de ensaios de compactação, índice de suporte Califórnia, compressão simples, compressão diametral e triaxial cíclico (módulo de resiliência).

- Avaliar a influência da energia de compactação no desempenho mecânico do agregado reciclado misto e misturas solo-ARM.

- Analisar o efeito da cimentação própria do agregado reciclado misto e das misturas soloARM ao longo do tempo por meios dos ensaios de compressão simples, compressão diamentral e triaxial cíclico com diferentes tempos de cura.

- Analisar o efeito da adição de solo ao agregado reciclado por meios dos ensaios de compactação, CBR, compressão diamentral e triaxial cíclico nas misturas de solo-ARM.

- Comparar os resultados de caracterização física e comportamento mecânico do ARM e das misturas solo-ARM com agregados naturais (AN) e uma mistura de solo-AN.

\subsection{JUSTIFICATIVA}

A quantidade gerada de resíduos sólidos da construção civil, na cidade de São Carlos, estimada em $600 \mathrm{~m}^{3} /$ dia por Córdoba (2010), tem sido motivo de preocupação, devido os diversos impactos ambientais causados e pelo descarte de um material que pode ser utilizado para outras funções, como por exemplo, em camadas de pavimentos. Dessa forma, o uso de materiais reciclados de resíduos de construção e demolição é uma alternativa para que os problemas 
decorrentes deste processo sejam minimizados, com vistas à sustentabilidade do setor construtivo.

Além de contribuir para soluções mais sustentáveis, a utilização de agregados reciclados, pode contribuir para melhorias das características físicas e mecânicas de camadas de pavimentos, em relação a camadas construídas com solo e agregados naturais, o que justifica o estudo do emprego de agregados reciclados da construção civil produzidos na cidade de São Carlos como material alternativo ao agregado natural, na estabilização granulométrica de sub-bases e bases de pavimentos. Apesar dos seus benefícios não serem tão óbvios quanto utilizar misturas compostas exclusivamente por agregado reciclado, as misturas solo-agregado podem apresentar melhores condições de trabalhabilidade e melhores propriedades mecânicas, devido à propriedade coesiva do solo.

\subsection{ESTRUTURA DO TRABALHO}

Este trabalho é apresentado em cinco capítulos. No primeiro capítulo, encontra-se uma breve introdução ao estudo, seus objetivos e justificativas. O segundo capítulo apresenta a revisão bibliográfica, abordando aspectos relevantes para o desenvolvimento da pesquisa. No terceiro capítulo, são apresentados os materiais e os métodos que compõem o programa experimental. No quarto capítulo, são apresentados e discutidos os resultados dos ensaios de caracterização física e mecânica para os materiais pesquisados. No quinto capítulo, são apresentadas as principais conclusões desse trabalho e algumas sugestões para pesquisas futuras. 


\section{REVISÃO BIBLIOGRÁFICA}

Neste capítulo, são apresentadas algumas considerações a respeito dos agregados reciclados de resíduos de construção e demolição, enfatizando suas características físicas e seu comportamento mecânico.

\subsection{ESTABILIZAÇÃO DE SOLOS}

Os solos são materiais que resultam do intemperismo das rochas por desintegração física ou decomposição química. Em pavimentação, os solos compõem o subleito, mas podem ser utilizados como material para sub-base, base e revestimento primário.

A estabilização de solos torna-se necessária quando esses materiais em seu estado natural não oferecem propriedades mínimas ou adequadas à finalidade a que são destinados. Entre as técnicas de estabilização de solos, a estabilização física é uma das mais utilizadas em pavimentação.

$\mathrm{Na}$ estabilização física, dois princípios são utilizados para alterar as propriedades do solo. $\mathrm{O}$ primeiro consiste no rearranjo de partículas por meio da compactação e o segundo compreende a adição ou a retirada de partículas em um processo chamado de correção granulométrica.

A compactação aumenta a densidade do solo, melhorando sua resistência e sua durabilidade. Isto é obtido pela redução dos vazios da mistura, por meio da energia de compactação imposta. A redução dos poros também inibe a percolação da água e a erosão, aumentando a durabilidade.

Em pavimentação, as camadas estabilizadas granulometricamente são constituídas por solos naturais, mistura de solos, mistura de diferentes tipos de agregados, ou mesmo por diversas combinações de materiais não convencionais que apresentem estabilidade e durabilidade adequadas para resistir às ações climáticas e às cargas do tráfego, quando compactadas de maneira conveniente, podendo ser empregadas como reforço do subleito, sub-bases ou bases (DER-PR- ET-DE-P00/007, 2006).

$\mathrm{Na}$ estabilização granulométrica, procura-se obter um material bem graduado e com percentagem limitada de partículas finas. Uma mistura estabilizada granulometricamente comumente utilizada em sub-bases e bases de pavimentos são as misturas de solo-agregado. 
Solo-agregado são misturas usinadas compostas por solo e agregado pétreo britado, que apresentam elevada estabilidade e durabilidade, para resistir às cargas do tráfego e ação dos agentes climáticos, quando adequadamente compactadas (DER-PR- ET-DE-P00/006, 2006).

O uso de materiais não convencionais em pavimentação, deve ser incentivado afim de contribuir para soluções mais sustentáveis no processo construtivo, gerando inclusive benefícios técnicos e econômicos, como por exemplo, borracha de pneus, rejeitos de mineração e os resíduos de construção civil, esse último objeto desta pesquisa.

\subsection{RESÍDUOS DE CONSTRUÇÃO E DEMOLIÇÃO}

No Brasil, os resíduos sólidos de construção e demolição são definidos e classificados pela resolução do Conselho Nacional do Meio Ambiente no 307 (CONAMA, 2002). De acordo com esta resolução, os resíduos sólidos de construção são materiais oriundos de obras civis como construções, reformas, reparos e demolições, assim como de preparação e de escavação de terrenos e são classificados nas classes A, B, C e D.

Os materiais reutilizáveis ou recicláveis como agregados, tais como blocos, concreto em geral, rochas, tijolos e telhas, são pertencentes à classe A. Os resíduos que fazem parte da classe B são compostos por plásticos, papéis, metais, vidros e madeiras e gesso podem ser reciclados para outros fins. Os resíduos da classe C são os resíduos para os quais não foram desenvolvidas tecnologias ou aplicações economicamente viáveis que permitam a sua reciclagem ou recuperação. As definições da classe B e C, foram implementadas pela resolução CONAMA $n^{\circ}$. 431/2011 que alterou o artigo 3ํำ da resolução CONAMA n n $^{\circ}$ 307/2002. Por fim, os resíduos da Classe D são resíduos perigosos oriundos do processo de construção, tais como tintas, solventes, óleos ou aqueles contaminados ou prejudiciais à saúde, originados de demolições, reformas e reparos de clínicas radiológicas, instalações industriais e outros. A resolução do CONAMA nº. 348/2004 inclui o amianto à classe de resíduos perigosos.

O setor da construção civil é responsável pelo consumo de 50\% de matérias-primas da natureza e de $40 \%$ da energia, além disso, representa em média $50 \%$ da massa dos resíduos produzidos (OIKONOMOU, 2005), e causam diversos impactos ambientais. A fim de proteger o meio ambiente e contribuir para a economia, a gestão dos resíduos sólidos por meio de reciclagem e reutilização merece atenção de pesquisadores. 
A quantidade gerada dos resíduos de construção e demolição é influenciada por muitos fatores, dentre eles, podem-se citar as práticas de construção e demolição adotadas, fatores de mercado e econômicos, a estrutura reguladora que fornece incentivos para minimizar a geração de resíduos nos canteiros de obra e as dificuldades para dispor os resíduos nos aterros (BRASILEIRO e MATTOS, 2015).

O relatório da Agência de Proteção Ambiental dos Estados Unidos de 2007 mostrou que a construção e demolição de edifícios geram uma quantidade aproximada de 160 milhões de toneladas/ano de resíduos no país, sendo que a indústria da construção civil é responsável por cerca de dois terços do total de resíduos sólidos não industriais produzidos. Esse resíduo é originado aproximadamente em $48 \%$ das demolições, $44 \%$ das reformas e em $8 \%$ das novas construções (BAPTISTA e ROMANEL, 2013).

Estima-se que na Europa são gerados em média 890 milhões de toneladas de resíduos de construção e demolição por ano (SAÉZ et al. 2011).

No Brasil, foram coletados no ano de 2016 cerca de 124 mil toneladas/dia, o que resulta em torno de 45 milhões de toneladas/ano (ABRELPE, 2016).

Em São Carlos-SP, a geração total de RCD foi estimada em cerca de 145 mil toneladas/ano, a partir do volume de cargas das empresas coletoras (MARQUES NETO, 2003). Na geração de resíduos, as reformas contribuiram com $60 \%$, a construção de residências térreas $15 \%$, as construções verticais $10 \%$, demolições $5 \%$ e outros 5\%. Córdoba (2010) estimou a provável geração de resíduos da cidade de São Carlos, por meio do monitoramento dos destinos finais no ano de 2009, em cerca de $600 \mathrm{~m}^{3} /$ dia o que corresponde em massa a aproximadamente 260 mil toneladas/ano.

As pesquisas de Marques Neto (2003) e Córdoba (2010), indicam que, na cidade de São Carlos, de 2003 para 2009, houve um aumento de quase 100\% na geração de resíduos. Contudo, os diferentes métodos para quantificação, podem mascarar esse crescimento.

De maneira hipotética, considerando que $90 \%$ dos $600 \mathrm{~m}^{3} /$ dia de resíduos de construção e demolição tem potencial de reciclagem e que uma via urbana comum com cerca de $8 \mathrm{~m}$ de largura, seria possível construir $500 \mathrm{~m} /$ dia de base ou sub-base de pavimento urbano de $15 \mathrm{~cm}$ de altura com agregados reciclados da cidade, ou o equivalente à $180 \mathrm{~km}$ em um ano. 


\subsubsection{Composição dos resíduos de construção e demolição e dos agregados reciclados}

Assim como a geração, a composição dos resíduos de construção e demolição depende das características de cada região, como técnicas construtivas e matérias-primas disponíveis. De acordo com Porto e Silva (2008), a composição dos resíduos de demolições e sobras de construções é bastante variada devido à grande quantidade de materiais envolvidos na indústria da construção civil.

Os resíduos de construção e demolição gerados em países da União Européia, por exemplo, incluem diversos materiais, principalmente inertes, tais como: materiais de escavação, de construção e manutenção de estradas, mas também podem conter tipos de resíduos perigosos, que podem estar presentes em proporções significativas quando os edifícios são demolidos ou reformados (SAÉZ et al. 2011).

De acordo com a NBR 15114/2004 -“Agregados reciclados de resíduos sólidos da construção civil - Execução de camadas de pavimentação - Procedimentos" os agregados reciclados são materiais granulares provenientes do beneficiamento de resíduos de construção ou demolição de obras civis, que apresenta características técnicas para a aplicação em obras de edificação e infraestrutura. Os agregados reciclados podem ser classificados em agregados reciclados mistos e agregados reciclados de concreto.

No Brasil, diversos pesquisadores como Trichês e Kryckyj (1999), Carneiro (2001) e Marques Neto (2003), estudaram a composição dos resíduos de construção e demolição nas cidades de Florianópolis-SC, Salvador-BA e São Carlos-SP, respectivamente. Os resultados concordam que uma parcela significativa dos resíduos de construção e demolição é composta por materiais a base de concreto e materiais cerâmicos, que após reciclagem podem gerar os agregados reciclados de concreto ou os agregados reciclados mistos.

Os agregados reciclados de concreto (ARC) são os obtidos do beneficiamento de resíduo pertencente à classe $\mathrm{A}$, compostos na sua fração graúda, de no mínimo $90 \% \mathrm{em}$ massa de fragmentos à base de cimento Portland e rochas. Os agregados reciclados mistos (ARM) são obtidos do beneficiamento de resíduo de classe $\mathrm{A}$, compostos na sua fração graúda com menos de 90\% em massa de materiais cimentícios e rochas (ABNT 15115/2004). 


\subsubsection{Reciclagem de RCD}

O reaproveitamento de resíduos da construção já é praticado há muito tempo, tem-se registro de que os romanos já empregavam tijolos, telhas e cerâmica moída como pozolanas (SANTOS, 1975).

Desde o final da década de 1970, a reutilização de concreto e alvenaria como materiais para estradas são práticas comuns nos Países Baixos (MOLENNAR e NIEKERK, 2002).

A valorização e a reciclagem de resíduos de construção tornam-se necessárias devido as atuais restrições econômicas e de sustentabilidade. Numa época em que a proteção ambiental está em alta, o uso de materiais reciclados oferece como vantagens as reduções de disposição de resíduos em aterros, de exploração de agregados naturais e dos custos de transportes com movimentação de materiais (MELBOUCI, 2009).

$\mathrm{Na}$ Europa, a taxa de reciclagem de resíduos de construção é muito variada, com países onde as taxas são maiores que 90\%, como Dinamarca e Holanda, até países com taxas menores que 10\%, como Grécia e Portugal (BIO Intelligence Service, 2011).

No Brasil, a reciclagem de resíduos de construção civil iniciou-se nos anos 80, com a utilização de pequenos moinhos instalados no canteiro de obras, e os resíduos de alvenaria eram reaproveitados para a produção de argamassas (LIMA, 1999).

A reciclagem de resíduos de construção e demolição consiste no processo transformação desses materiais para posterior reaproveitamento. O sistema de reciclagem de resíduo de construção é feito em usinas recicladoras. De maneira geral, são feitas, primeiramente, a retirada de componentes como ferro, madeira, plástico e papel (que são reciclados para outros fins), e são separados materiais que eventualmente demandem mais cautela na reciclagem, como o gesso. Após esta primeira separação, os resíduos são britados, separados por peneiramento e armazenados.

Uma medida importante para facilitar a reciclagem e valorizar os resíduos de construção e demolição é adotar práticas construtivas e de demolição organizadas, com separação de resíduos em classes no canteiro de obra. Dessa forma, durante o processo de reciclagem nas usinas recicladoras, a etapa de retirada de materiais indesejáveis não será necessária. Além disso, no caso dos agregados reciclados de concreto, a separação de materiais britados e cimentícios já em canteiro facilita o processo de produção. 


\subsubsection{Emprego de agregados reciclados de RCD}

A construção civil e a pavimentação são setores que apresentam grande potencial para o uso de resíduos sólidos. Dentre as várias possibilidades, os agregados reciclados podem ser aproveitados nas composições de argamassas de assentamento e revestimento, de concretos, de pré-moldados (blocos, meio-fio, dentre outros), e como material de construção de camadas de base e sub-base para pavimentação e de revestimento primário de vias.

No Brasil, nas cidades de São Paulo e Belo Horizonte, a partir da década de 80, iniciaram-se estudos com a finalidade de aproveitar este material em diferentes formas de aplicação, entre as quais se destacaram: a fabricação de elementos pré-moldados e a utilização na pavimentação urbana (TRICHÊS e KRYCKYJ, 1999).

Nos últimos 30 anos, a viabilidade do uso dos RCD tem sido confirmada como material em camadas de base, sub-base e reforço de subleito para rodovias de baixo volume de tráfego. $\mathrm{O}$ estímulo para o desenvolvimento de técnicas para a reciclagem de RCD como material pavimentação vem dos altos custos e da elevada demanda de materiais naturais.

Uma vantagem importante é que a execução de bases construídas com agregados reciclados pode ser mais econômica, em torno de $85 \%$, quando comparada a bases de brita graduada tratada com cimento, e em 25\%, quando comparado ao uso de brita graduada (LEITE, 2007).

Contudo, ao utilizar materiais reciclados, vários aspectos complementares de projeto e execução devem ser analisados. Devido à heterogeneidade desses materiais, podem ser necessárias adequações de dosagem e projeto, ressaltando a importância de um controle tecnológico (BENNERT et al. 2000).

\subsection{CARACTERIZAÇÃO DO AGREGADO RECICLADO MISTO}

A variabilidade de composição dos agregados reciclados é maior que a de agregados naturais, devido as diferentes fontes de onde são obtidos os resíduos a serem reciclados. Em função da variabilidade, os agregados reciclados de resíduos sólidos da construção civil possuem particularidades de comportamento em relação aos materiais convencionais naturais empregados na pavimentação (BARBUDO et al., 2012). 
A especificação brasileira ABNT 15115/2004 para uso de AR em camadas de bases, sub-bases e reforços de subleito de pavimentos de baixo volume de tráfego $\left(\mathrm{N} \leq 10^{6}\right)$ recomenda algumas características e propriedades desejáveis do agregado reciclado (AR), como se apresenta na Tabela 1.

Tabela 1: Características e propriedades desejáveis dos AR (Fonte: ABNT 15115/04).

\begin{tabular}{|c|c|c|}
\hline \multicolumn{3}{|c|}{ Características } \\
\hline Dimensão máxima característica (mm) & 63,5 & \\
\hline Coeficiente de uniformidade & $\geq 10$ & \\
\hline$\%$ passante na peneira $\mathrm{n} .40(0,42 \mathrm{~mm})$ & 10 a $40 \%$ & \\
\hline Grãos lamelares da fração graúda $(4,8 \mathrm{~mm})$ & $\leq 30 \%$ & \\
\hline Materiais indesejáveis & 2 a $3 \%$ & \\
\hline \multicolumn{3}{|c|}{ Propriedades mecânicas e de expansão } \\
\hline & CBR (\%) & Expansão (\%) \\
\hline Camada de reforço (Energia Normal ou superior) & $\geq 12$ & $\leq 1,0$ \\
\hline Camada de subbase (Energia Intermediária) & $\geq 20$ & $\leq 1,0$ \\
\hline Camada de base (Energia Intermediária) & $\geq 60$ & $\leq 0,5$ \\
\hline
\end{tabular}

As recomendações quanto as características físicas direcionam para uma mistura granulometricamente bem distribuída, e limita a quantidade de materiais lamelares e indesejáveis, para não comprometer o desempenho do material.

Na norma brasileira, o California bearing ratio (CBR) é a principal característica mecânica para o emprego de agregado reciclado em camadas de reforço de subleito, sub-base e base de pavimentos.

Além dos parâmetros recomendados pela norma, outras características físicas e mecânicas como densidade, absorção, degradação, auto-cimentação e módulo de resiliência do agregado reciclado vêm sendo estudadas, em diversas regiões do mundo, por pesquisadores como Molenaar e Van Niekerk (2002), Poon e Chan (2006), Melbouci (2009), Leite et al. (2011), Barbudo et al. (2012) e Arulrajah et al. (2012), Agrella et al. (2012) a fim de compreender melhor o comportamento dos agregados reciclados.

\subsubsection{Características físicas dos agregados reciclados}

Devido à heterogeneidade dos agregados reciclados, o estudo de suas características físicas é necessário para entender o comportamento do material. Zordan (2003) concluiu que a alta porosidade dos agregados reciclados resulta em altas porcentagens de absorção de água e baixa densidade do material. Pesquisas realizadas por Leite et al. (2011), Barbudo et al. (2012), Xuan et al. (2015) indicam que a absorção de água do agregado reciclado é influenciada pela natureza 
dos materiais que os compõem, sendo, em geral, maiores para os agregados mistos do que para os de concreto. Para grandes ocorrências de materiais cerâmicos, altamente porosos, como tijolos e telhas, a absorção do agregado reciclado misto aumenta e a sua densidade diminui significativamente.

A natureza dos materiais que compõe os agregados reciclados influencia também em sua capacidade de auto-cimentação. Estudos realizados por Poon et al. (2006), Grubba (2009) Leite et al. (2011), Sousa (2009) apontam para um ganho de resistência devido a uma parcela de cimento não hidratado presente nas partículas de concreto, expostas durante a compactação. Para Poon et al. (2006) a fração fina (menor que $0,15 \mathrm{~mm}$ e entre $0,15-0,30 \mathrm{~mm}$ ) do agregado reciclado de concreto é a que mais contribui para a auto-cimentação, no entanto, Sousa (2011) observou ganhos significativos de resistência mesmo com a substituição dessa fração em misturas tipo solo-ARC (70/30).

Também é possível inferir a forma do grão com base na sua composição. Os resultados obtidos por Leite et al. (2011) mostraram que os materiais de concreto têm grãos cúbicos predominantes, enquanto materiais cerâmicos tem uma porcentagem maior de grãos lamelares, concordando com os resultados obtidos por Oliveira (2007).

Avaliando a forma de partículas cerâmicas de tijolos triturados, Brito et al. (2005) concluiu que os agregados reciclados apresentaram geralmente maior incidência de partículas lamelares para partículas maiores, que só diminuíram com diminuição do tamanho de partícula.

A abrasão Los Angeles dos agregados reciclados é maior do que a encontrada para os agregados naturais, e aumenta com a presença de materiais cerâmicos. Este fato também está relacionado com a baixa densidade e alta degradação do agregado reciclado, principalmente os agregados reciclados mistos (BARBUDO et al. 2012 e ARULRAJAH et al. 2012).

Apesar da maior tendência a degradação dos agregados reciclados mistos, em relação aos agregados reciclados de concreto, o uso desse material é vantajoso devido a fatores econômicos e ambientais advindos do aproveitamento dos materiais cerâmicos.

\subsubsection{Dosagem de misturas com agregado reciclado}

No Brasil não existem normas que regulamentam a dosagem das misturas de agregados reciclados. Contudo especificações nacionais e internacionais de misturas solo-agregado natural, em geral, procuram enquadrar os materiais em uma curva granulométrica, de forma a 
garantir uma adequada distribuição das partículas, que permita o preenchimento dos vazios da mistura, aproximando-a da curva de densidade máxima.

A norma DNER ES 303/97 Pavimentação - base estabilizada granulometricamente, dispõe sobre faixas granulométricas para a estabilização de solos, misturas de solos e materiais britados ou produtos provenientes de britagem. As faixas granulométricas dessa norma são apresentadas na Tabela 2. As graduações são mais grossas para a faixa A e vão se torando mais finas, até a faixa F. Sendo as faixas C e D as mais populares em misturas solo-agregado.

Tabela 2: Faixas granulométricas (Fonte: DNER ES 303/97).

\begin{tabular}{|c|c|c|c|c|c|c|c|}
\hline Tipos & \multicolumn{4}{|c|}{ Para $\mathrm{N}>5 \times 10^{6}$} & \multicolumn{2}{|c|}{ Para $\mathrm{N}<5 \times 10^{6}$} & \multirow{2}{*}{$\begin{array}{c}\text { Tolerâncias } \\
\text { da faixa } \\
\text { de projeto }\end{array}$} \\
\hline Peneiras & $\mathrm{A}$ & B & $\mathrm{C}$ & $\mathrm{D}$ & $E$ & $\mathrm{~F}$ & \\
\hline 2" & 100 & 100 & - & - & - & - & \pm 7 \\
\hline 1" & - & $75-90$ & 100 & 100 & 100 & 100 & \pm 7 \\
\hline $3 / 8^{\prime \prime}$ & $30-65$ & $40-75$ & $50-85$ & $60-100$ & - & - & \pm 7 \\
\hline $\mathrm{N}^{\circ} 4$ & $25-55$ & $30-60$ & $35-65$ & $50-85$ & $55-100$ & $10-100$ & \pm 5 \\
\hline $\mathrm{N}^{\circ} 10$ & $15-40$ & $20-45$ & $25-50$ & $40-70$ & $40-100$ & $55-100$ & \pm 5 \\
\hline $\mathrm{N}^{\circ} 40$ & $8-20$ & $15-30$ & $15-30$ & $25-45$ & $20-50$ & $30-70$ & \pm 2 \\
\hline $\mathrm{N}^{\circ} 200$ & $2-8$ & $5-15$ & $5-15$ & $10-25$ & $6-20$ & $8-25$ & \pm 2 \\
\hline
\end{tabular}

\subsubsection{Parâmetros de projeto}

\subsubsection{Ensaio de compactação}

O ensaio de compactação é base fundamental para a dosagem dos materiais geotécnicos empregados em pavimentos, por meio do qual são determinados os valores de massa específica seca máxima e umidade ótima, a serem praticados nas obras.

No que se refere aos parâmetros obtidos dos ensaios de compactação, em geral, têm sido observados valores de massa específica aparente seca máxima menores e umidades ótimas maiores para os agregados reciclados que para os agregados naturais. Com o aumento da quantidade de cerâmica na composição do agregado reciclado, a umidade ótima aumenta e a densidade seca máxima diminui (POON e CHAN, 2006; BARBUDO et al. 2012; AGRELLA et al. 2012).

Quanto à energia de compactação, autores como Grubba (2009) e Leite et al. (2011) observaram que o aumento da energia de compactação provoca um incremento na massa especifica aparente seca máxima e uma diminuição da umidade ótima. 
Estudos realizados por Molenaar e Niekerk (2002) mostraram que fatores como a graduação e a composição do agregado reciclado influenciam nas características mecânicas, no entanto entre as variáveis estudadas, o grau de compactação é o fator que mais exerceu influência no comportamento mecânico do agregado reciclado. Apesar dos resultados, por vezes inconsistentes, foi possível concluir que para um grau de compactação variando de 97 a 105\%, o aumento do grau de compactação proporcionou efeitos benéficos para o módulo de resiliência.

Nesse sentido, Leite (2011) concluiu que a energia de compactação tem uma forte influência sobre as propriedades de deformabilidade do agregado reciclado. Isso ocorre porque os agregados sofrem uma redistribuição de tamanhos durante a compactação, devido à quebra de grãos, principalmente quando compactados na energia modificada. Além disso, após a compactação houve mudança na forma dos AR, com um aumento na porcentagem de grãos cúbicos na mistura.

Devido à mudança nas características dos agregados reciclados, causada pela quebra dos grãos durante a compactação, o desempenho desses materiais requer uma investigação detalhada. Pois, se não houver a degradação por compactação, ela poderá ocorrer devido ao tráfego e contribuir para a ocorrência de deformação permanente e diminuir a vida útil do pavimento.

Arulrajah et al. (2012) estudaram a degradação do agregado reciclado devido à compactação e concluíram que a distribuição granulométrica de misturas com tijolos triturados mudaram mais do que as de misturas com ARC. Isso mostra que a degradação da mistura cerâmica é maior do que a da mistura com concreto e rochas trituradas.

Este fato também foi verificado por Grubba (2009), que obteve uma degradação menor para o ARC que as obtidas por Motta (2005) e Leite (2007), para o ARM.

Quanto ao tipo de compactação, Fernandes et al. (2009), observaram que para o ARM há uma maior quebra dos grãos causada pela compactação por impacto, do que por vibração.

Em resumo, pode-se dizer que, em geral, os ARM possuem menor densidade, maior absorção de água, uma maior porcentagem de grãos lamelares, maior abrasão Los Angeles e maior degradação por compactação, devido à presença de materiais cerâmicos em sua composição, quando comparados ao ARC. Apesar desses fatores, a utilização de ARM ainda é uma alternativa vantajosa técnica e ambientalmente, pois promove a reutilização de uma gama maior de resíduos de construção e demolição. 


\subsubsection{Ensaio de CBR e expansão do ARM}

Um ensaio bastante difundido para a dosagem e uso de materiais granulares em camadas de pavimentos é o CBR. Este ensaio fornece informações indiretas sobre a resistência dos materiais compactados. A ABNT 15115/2004 também recomenda o CBR e a expansão como parâmetros para uso de agregados reciclados.

Poon e Chan (2006) concluíram que o CBR do agregado reciclado de concreto (66\%) de Hong Kong é menor que o de agregados naturais $(85 \%)$, e ainda menor em agregados reciclados de concreto com adição de 50\% tijolos (43\%), quando compactados na energia normal. Já Melbouci (2009), estudando agregados reciclados compactados na energia modificada, encontrou um CBR de $128 \%$ para o ARC e de $83 \%$ para o ARM.

Jiménez et al. (2011), estudando diferentes tipos de agregados reciclados, encontrou valores de CBR iguais a $152 \%$ para os agregados naturais, de $97 \%$ a $138 \%$ para os ARC e $62 \%$ a $94 \%$ para agregados reciclados mistos. Arulrajah et al. (2012), obteve valores de 103\% a 131\% para os ARM (50\% ARC e $50 \%$ ARC), e $118 \%$ a $160 \%$ para os ARC, quando compactados na energia modificada.

Estes resultados mostram que os agregados reciclados podem apresentar desempenho diferentes, o que pode ser justificado pela variabilidade desses materiais. Mesmo quando se trata dos agregados reciclados de concreto, os valores encontrados podem apresentar diferenças significativas, dependendo da qualidade do concreto utilizado na produção do agregado. No geral, pesquisadores observam que os agregados naturais possuem CBR maiores que os ARC, e os ARC possuem CBR maiores que os ARM.

Contudo, Grubba (2009), obteve valores maiores de CBR para o agregado reciclado de concreto $(172 \%)$ do que para o agregado natural (142\%) quando compactados na energia modificada. $\mathrm{O}$ alto valor de CBR obtido para o ARC dá mais um indício que a qualidade dos resíduos utilizados na produção dos agregados reciclados está diretamente relacionada com o desempenho do material.

Leite et al. (2011), estudando o efeito na energia de compactação de um agregado reciclado misto, obteve valores de CBR na ordem de $73 \%$ e $117 \%$ para as energias intermediária e modificada, respectivamente. Isso mostra que o CBR do ARM aumenta com o incremento da energia de compactação, nesse caso, o aumento foi de 60\%. Já para o ARC, estudado por 
Grubba (2009), o CBR de 125\%, na energia intermediária, aumentou em cerva de $40 \%$ quando compactado na energia modificada.

Motta (2005), estudou o CBR do ARM ao longo do tempo de cura e obteve um aumento de $24 \%, 55 \%$ e $67 \%$ nos valores de CBR aos 28,90 e 180 dias, respectivamente.

No que se refere à expansão dos agregados reciclados, em geral, as pesquisas indicam que os agregados reciclados possuem baixa expansão, com valores menores que $0,5 \%$, o que é um fator positivo para o uso como materiais de pavimentação.

\subsubsection{Estudo de propriedades mecânicas dos AR}

Outras propriedades mecânicas podem dar evidências do desempenho do material ou ainda destacar particularidades de seu comportamento, como o ganho de propriedade ao longo do tempo.

Poon et al. (2006), estudando a fração fina do agregado reciclado de concreto, verificaram o ganho de resistência ao longo do tempo, o que foi atribuído à auto-cimentação. Foram avaliadas as RCS de diferentes graduações e os resultados mostraram que o maior ganho de resistência (em 7 dias) foi da mistura contendo a fração fina entre 0,3-0,6 mm. Foram comparadas duas frações finas de ARC, uma contendo o dobro da fração 0,3-0,6 mm que a outra, as RCS mostraram que o material com maior fração ativa $(0,3-0,6 \mathrm{~mm})$ teve um ganho maior da propriedade.

Os autores ainda reforçam que os materiais que compõem o concreto original e a cura são fatores decisivos para a quantidade disponível de cimento não hidratado e de silicato bicálcico $\left(\mathrm{C}_{2} \mathrm{~S}\right)$ presentes na argamassa da fração fina do ARC.

Xuan et al. (2015), estudaram sobre o comportamento de agregados reciclados de concreto e mistos, e concluíram que o aumento do teor de alvenaria pode comprometer o desempenho mecânico do agregado reciclado. Já os aumentos do grau de compactação e do teor de cimento tendem a aumentar a RC, RT e módulo de elasticidade desses materiais.

Essas observações já haviam sido sinalizadas por Arm (2001), Poon et al., (2006), Grubba (2009) que observaram o aumento de RC, RT e MR com o aumento da energia de compactação e com o tempo de cura (devido à auto-cimentação do ARC). 
Grubba (2009) encontrou para o ARC valores de RC de $200 \mathrm{kPa}$, para a energia intermediária, e de $330 \mathrm{kPa}$, para a energia modificada; sendo que esses valores praticamente dobram para 7 dias de cura. Aos 90 dias de cura a RCS do ARC, em ambas energias de compactação, são semelhantes, o que indica uma cimentação mais efetiva para a energia intermediária, este fato, pode ter ocorrido devido ao maior teor de água disponível para hidratação do cimento na energia intermediária. Os valores de RT e MR também tiveram aumento significativo ao longo do tempo de cura, devido à cimentação do agregado reciclado.

Arualrajah et al. (2012) verificaram que a adição de até $25 \%$ tijolos demolidos no agregado reciclado de concreto e em rochas trituradas teve pouca influência no módulo de resiliência e na deformação permanente. As misturas com 25\% tijolos - 75\% ARC e 25\% tijolos - 75\% rochas trituradas tiveram maior coesão que as misturas com menores percentuais de tijolos. Isso dá indícios que a maior degradação dos tijolos, pode ter levado a um melhor entrosamento das partículas, devido ao preenchimento dos vazios da mistura pelas partículas finas. Os autores concluíram ainda que as propriedades cimentantes das misturas de tijolos-ARC podem levar a menor deformação permanente e módulo resiliente mais elevado comparado às misturas de tijolos- rochas trituradas.

Grégoire et al. (2015) verificaram que o teor de água influencia no módulo resiliente e deformação permanente dos agregados reciclados, sendo que para corpos de prova moldados com umidades acima da ótima, os módulos de resiliência obtidos são menores e a deformação permanente maior, como já é esperado mesmo para outros materiais. Para o ARC, o módulo de resiliência do material compactado na energia modificada, para uma tensão em torno de 400 $\mathrm{kPa}$ o MR foi de $250 \mathrm{MPa}$ e, para um agregado misto, em torno de $180 \mathrm{MPa}$.

Quanto à influência do teor de água e grau de compactação nas propriedades de módulo resiliente e deformação permanente, estudos realizados por Arualrajah et al. (2012) indicaram que os agregados reciclados, com teores de umidade abaixo da ótima, possuem módulo de resiliência mais elevados e menores deformações permanentes. Segundo os autores geralmente os tijolos com ARC e rochas, com $98 \%$ de grau de compactação e 70\% da umidade ótima, apresentam desempenhos satisfatórios.

Grégoire et al. (2015) mostraram que o aumento da umidade em relação à ótima leva a um pior desempenho mecânico dos agregados reciclados. Quanto ao grau de compactação, quando 
compactados a 97\% e 100\% da massa específica seca máxima, esses materiais não apresentaram diferenças significativas em seu comportamento mecânico.

Leite et al. (2011) concluíram que o módulo de resiliência do agregado reciclado misto aumentou com o incremento da energia de compactação. Para a energia intermediária, foram obtidos módulos que variavam de 160 a $440 \mathrm{MPa}$, e para a energia modificada, os valores encontravam-se na faixa de 200 a $500 \mathrm{MPa}$. Baseado nesses resultados, as autoras concluíram que o ARM apresentou módulos de resiliência compatíveis com ARC e AN.

Para um pavimento de baixo volume de tráfego, Grubba (2009) obteve módulos de ARC em torno de $180 \mathrm{MPa}$, sem cura, e $430 \mathrm{MPa}$, aos 90 dias de cura, na energia intermediária. Para a energia modificada, os valores obtidos foram de cerca de $230 \mathrm{MPa}$, sem cura, e $450 \mathrm{MPa}$, aos 90 dias de cura, mostrando mais uma vez a importância da cura para o ganho de resistência por auto-cimentação.

\subsection{MISTURAS SOLO-AR}

As misturas de solo-AR é uma alternativa importante para uso em pavimentos, uma vez que geralmente apresentam características de resistência suficientes para uso em camadas de base e sub-base, além de serem economicamente mais vantajosas que outras convencionais como brita graduada, solo-cimento e solo-AN.

Apesar dos ganhos ambientais não serem tão óbvios quanto usar exclusivamente $A R$, misturas de solo-AR podem ser mais vantajosas do ponto de vista da trabalhabilidade e facilidade na compactação. Pois, a adição de solo, promove um melhor rearranjo das partículas, preenchendo os vazios da mistura melhorando a coesão.

Da mesma forma que para o AR, não existem normas que regulamentam sobre a dosagem de misturas de solo-AR, o que dificulta o processo de ajuste de uma curva granulométrica. Apesar disso, pesquisadores têm utilizado normas de materiais convencionais para nortear a dosagem dessas misturas, um exemplo é a norma DNER ES 303/97, utilizada por Grubba (2009) e Sousa (2011) para dosagem das misturas solo-ARC. 


\subsubsection{Compactação solo-AR}

Em 1999, Trichês e Kryckyj avaliaram a viabilidade do uso de resíduos de construção civil como material para pavimentação, adicionando diferentes teores de solo ao RCD. Os autores observaram que a massa específica aparente seca tendeu a crescer com a incorporação de um solo areno-siltoso na mistura, pois este preenche os vazios da mistura. Para a adição de um solo argiloso a massa específica aparente seca diminuiu. Isso foi justificado pela granulometria do material argiloso que, embora fina, não preenche todos os vazios da mistura, dificultando a compactação.

Os resultados de compactação realizados por Redivo (2011) indicam que a adição de material cerâmico provoca uma redução da massa específica aparente seca máxima e um aumento na umidade ótima das misturas com um solo arenoso. Esse aumento na umidade ótima foi atribuído à alta absorção de água do material cerâmico.

Estudando misturas solo-ARC, Grubba (2009) verificou que o solo argiloso (A-7-5), apresentou massa específica aparente seca máxima de $1,780 \mathrm{~g} / \mathrm{cm}^{3}$ e umidade ótima de $21,2 \%$, a mistura de ARC apresentou valor maior de massa específica aparente seca máxima $\left(1,928 \mathrm{~g} / \mathrm{cm}^{3}\right)$ e umidade ótima menor $(11,0 \%)$.

Para a mistura com $75 \%$ de ARC e $25 \%$ de solo, verificou-se um aumento da massa específica em relação ao ARC in natura, sendo o valor encontrado de $2,030 \mathrm{~g} / \mathrm{cm}^{3}$, devido ao preenchimento dos vazios do ARC pela adição de solo. A umidade ótima da mistura também aumentou em $0,5 \%$ em relação ao ARC, isso pode ser explicado pela elevada umidade ótima do solo.

\subsubsection{CBR e expansão de misturas solo-AR}

Trichês e Kryckyj (1999), estudando a viabilidade do uso de resíduos de construção civil como material para pavimentação, obtiveram para a adição de até $30 \%$ de solo areno-siltoso um aumento do CBR da mistura, este fato foi atribuído a uma melhor compactação proporcionada pela presença de finos. Já a adição de pequenas quantidades de solo argiloso na mistura de $\mathrm{RCD}$, fez com que o CBR diminuísse, devido ao fato do solo apresentar um valor de CBR muito baixo.

Em 2001, Carneiro et al. estudou parâmetros de compactação de solos e misturas de solos com agregados reciclados mistos. O solo classificado como areia/areia siltosa/argilosa (A-2-4), de 
comportamento laterítico, apresentou um CBR de $114 \%$, e a mistura com adição de $30 \%$ de agregado reciclado misto graúdo, um CBR de $112 \%$, para a mistura com $30 \%$ de agregado reciclado miúdo e 70\% de agregado reciclado graúdo, o CBR foi de 100\%. Assim, percebeu-se que a adição de $30 \%$ de agregado graúdo ao solo, não provocou alteração no valor de CBR, e que a adição de agregado reciclado fino (30\% ARM+ 70\% solo) levou a uma redução pequena no valor de CBR em relação ao solo natural. Estes valores fizeram com que todas as misturas fossem propostas para uso como material de base e sub-base de pavimentos. Destaca-se que os altos valores de $\mathrm{CBR}$ apreciados para o solo estudo foram parcialmente atribuídos ao seu caráter laterítico.

Amorim (2013) estudou misturas de RCD misto britados em laboratório e um solo do tipo pedregulho/areia (A-1-a), de comportamento laterítico. O autor testou as dosagens de $85 \%$ solo$15 \%$ RCD, $75 \%$ solo- $25 \%$ RCD misto - $75 \%$ solo e $65 \%$ solo- $35 \%$ RCD misto. O incremento de RCD misto em até 35\%, elevou a umidade ótima da mistura, situação relacionada ao fato da absorção do RCD ser maior que a do solo, contudo exerceu pouca influência na massa específica, CBR e expansão.

Redivo (2011), analisando o comportamento das misturas realizadas com vários teores de cacos de telhas e com três tipos de solo, concluiu que, para o solo 1 (arenoso), os melhores resultados de CBR e expansão ocorreram para a adição de $30 \%$ de cacos de telhas, e para solos 2 e 3 (argilosos), os melhores resultados foram obtidos para as misturas com de $70 \%$ de cacos de telhas e $30 \%$ de solo. Os resultados estão resumidos na Tabela 3.

Tabela 3: Resumo dos valores de CBR e Expansão (Fonte: Redivo, 2011).

\begin{tabular}{ccccc}
\hline Solo & $\begin{array}{c}\text { CBR solo } \\
\text { (\%) }\end{array}$ & $\begin{array}{c}\text { (\%) de cacos de telha } \\
\text { da melhor mistura }\end{array}$ & $\begin{array}{c}\text { CBR } \\
\text { (\%) }\end{array}$ & $\begin{array}{c}\text { Expansão } \\
\text { (\%) }\end{array}$ \\
\hline 1 & 22 & 30 & 46 & 0 \\
2 & 7 & 70 & 36 & 0,15 \\
3 & 11 & 70 & 32 & 0,19 \\
\hline
\end{tabular}

A partir dos dados da Tabela 3, observa-se que a adição de cacos de telhas levou a um aumento no $\mathrm{CBR}$, para misturas com todos os tipos de solo, e à expansão praticamente nula para todas as misturas de solo-cacos de telha.

Estudando o comportamento mecânico dos agregados reciclados de concreto (ARC) e misturas solo-ARC, Grubba (2009), observou que a adição de 25\% de solo ao agregado reciclado não 
teve influência significativa sobre o módulo de resiliência e sobre a RCS. Já a resistência a tração teve um incremento de $80 \%$ com a adição de solo e o CBR diminuiu ligeiramente com a adição de solo, indo de $182 \%$ para $164 \%$.

Sousa (2011) complementou os estudos de iniciados por Grubba (2009) e no tocante às propriedades mecânicas, foi encontrado para a mistura solo-ARC valores de CBR da ordem de $228 \%$ (energia modificada).

Santos et al. (2015), ao estudar os custos de pavimentos construídos com agregado reciclado, fez a caracterização física de misturas de solo-ARC. O agregado utilizado na pesquisa apresentou um CBR de 101\% quando compactado na energia intermediária, enquanto o solo utilizado, classificado como argiloso (A-7-5), apresentou um CBR de $10 \%$. A primeira mistura analisada foi composta por $56 \%$ de agregado reciclado e $44 \%$ de solo, apresentou um CBR de $32 \%$ e, a mistura composta por $83 \%$ de agregado e $17 \%$ de solo, um CBR de $45 \%$. Isso mostra que a adição de solo provocou uma diminuição no valor de CBR e que quanto maior a proporção de solo na mistura menor o CBR, o que era esperado, uma vez que o solo possui um CBR baixo, estes resultados concordam com os obtidos por Oliveira (2007), que, estudando misturas de agregado reciclado mistos e de concreto com um solo argiloso, verificou uma redução acentuada no valor de CBR com a adição de solo.

Os resultados obtidos por Oliveira (2007), Grubba (2009), Souza (2011) e Santos et al, (2015), mostram que a tipo do solo para uso na composição solo-agregado reciclado é de fundamental importância para o desempenho dessas misturas.

Oliveira (2007), ao estudar o efeito da adição de solo ao ARM (50 \% de material cerâmico + 50 \% de concreto), realizou o ensaio de índice de degradação após compactação Proctor (IDp) obteve que, para a mistura exclusivamente composta por ARM, o IDp na energia intermediária foi de 8,6 . Com a adição de $20 \%$ de solo, o índice foi de 6,2 , e para a adição de $40 \%$ o valor foi 3,4. Isso mostra uma tendência a redução do IDp com a adição de solo, provavelmente devido ao melhor rearranjo das partículas durante a compactação pela adição de partículas finas.

\subsubsection{Ensaios complementares solo-AR}

O conhecimento de propriedades mecânicas complementares como resistencia à compressão (RC), resistência a tração RT e módulo de resiliência (MR) são importantes para entender o comportamento das misturas de solo-AR. 
Em relação à RC, Grubba (2009) obteve para a mistura 25\% solo- 75\% ARC uma resistência de aproximadamente $70 \mathrm{kPa}$ (sem cura), valor semelhante ao encontrado para o ARC puro. A RT foi de $5 \mathrm{kPa}$ (ARC puro) para $9 \mathrm{kPa}$ (com 25\% solo), dando indícios de uma contribuição da maior coesão do solo à mistura. Em relação à rigidez, a mistura de solo-ARC apresentou, para uma estrutura de pavimento de baixo volume de tráfego, o valor de $\mathrm{MR}$ de aproximadamente $230 \mathrm{MPa}$, cerca de $50 \mathrm{MPa}$ maior que a de ARC.

Diferente do que foi observado por Grubba (2009), os valores obtidos por Sousa (2011) mostraram que a RC e MR tiveram um incremento significativo com a adição de solo, sendo o ganho em torno de $40 \%$ na $\mathrm{RC}$, e de $300 \%$ no MR, obtendo valores de MR de $231 \mathrm{MPa}$, para o $\mathrm{ARC}$, e $614 \mathrm{MPa}$, para as misturas de ARC-solo. Os resultados de deformação permanente indicaram que o ARC acumula maior deformação que a mistura solo-ARC, mas tende à estabilização dessas deformações em 28 dias.

Tavira et al, (2018), estudando o uso de RCD com solos de escavação de pavimentos demolidos, obteve um MR em torno de $160 \mathrm{MPa}$, para a mistura solo escavado-RCD e, de $350 \mathrm{MPa}$, para uma mistura de solo natural-RCD. Esses valores compatíveis são compatíveis ao de misturas com agregado natural de calcário e solo natural que apresentaram valores em torno de $480 \mathrm{MPa}$ e $220 \mathrm{MPa}$, respectivamente.

É importante mencionar que quando o assunto é estudo de viabilidade, cada novo material requer grande esforço e ensaios para tentar assegurar um bom desempenho do material. Ensaios complementares ajudam a encontrar soluções que satisfaçam as condições de contorno de projeto de pavimentos, e a dosagem adequada dos materiais pode contribuir para maior durabilidade. 


\section{MATERIAIS E MÉTODOS}

Neste capítulo, apresentam-se os materiais empregados neste estudo, bem como os procedimentos de caracterização física e a composição das misturas com ARM, solo-ARM e solo- AN. Em seguida, apresentam-se os métodos utilizados para a preparação dos corpos de prova utilizados e para os ensaios de comportamento mecânico.

\subsection{PROGRAMA EXPERIMENTAL}

Os corpos de prova deste programa experimental foram produzidos tentando satisfazer uma faixa granulométrica de misturas solo-agregado, compostas totalmente por ARM ou com substituição parcial da fração fina por solo e uma mistura de referência composta por solo e agregado natural (AN). Ao todo, 4 misturas foram dosadas, a saber:

(1) mistura com agregado reciclado misto, composta exclusivamente por ARM.

(2) mistura solo- ARM, composta por $15 \%$ de solo e $85 \%$ de ARM.

(3) mistura solo- ARM, composta por $45 \%$ de solo e $55 \%$ de ARM.

(4) mistura solo-AN, composta por $30 \%$ de solo e $70 \%$ de AN.

Para a definição dos parâmetros de dosagem e de projeto, foram realizados os ensaios de compactação Proctor e de CBR (com medidas de expansão). Já para a caracterização mecânica e estudo da auto-cimentação, em diferentes tempos de cura foram realizados ensaios de resistência à compressão simples (RCS), resistência à tração por compressão diametral (RTCD) e o ensaio triaxial cíclico, para a determinação do módulo resiliente (MR).

A fim de avaliar o efeito na energia de compactação das misturas, os ensaios de compactação, CBR foram realizados nas energias intermediária e modificada. Para a mistura de referência, solo-AN, os ensaios foram realizados em corpos de prova compactados na energia modificada.

Os ensaios mecânicos complementares (RCS, RTCD e MR) foram realizados em CPs de ARM compactados nas energias intermediárias e modificada, sendo que a medida das propriedades, foram tomadas em diferentes de cura ( 0,7 e 28 dias), para compreender se houve autocimentação no ARM, devido à exposição de materiais cimentícios não-hidratados, advindos da 
degradação do AR durante a compactação e como ela se desenvolve em diferentes energias de compactação.

A auto-cimentação das misturas de solo-ARM foi observado para 0 e 7 dias. Essa condição foi escolhida porque a substituição da fração areia do ARM por solo implica em redução de componentes cimentantes.

Para as misturas de referência, solo-AN, optou-se pela compactação na energia modificada, por ser a energia comumente utilizada em misturas solo-agregado e pela avaliação imediata das propriedades, tendo em vista que os materiais naturais não contêm compostos cimentantes.

Na Figura 1, encontra-se um fluxograma ilustrando o programa experimental dos ensaios de RCS, RTCD e triaxial cíclico dos materiais pesquisados. Observando-se a Figura 1, pode-se entender de maneira objetiva, as misturas estudadas, as energias empregadas e os tempos de cura utilizados para cada mistura.

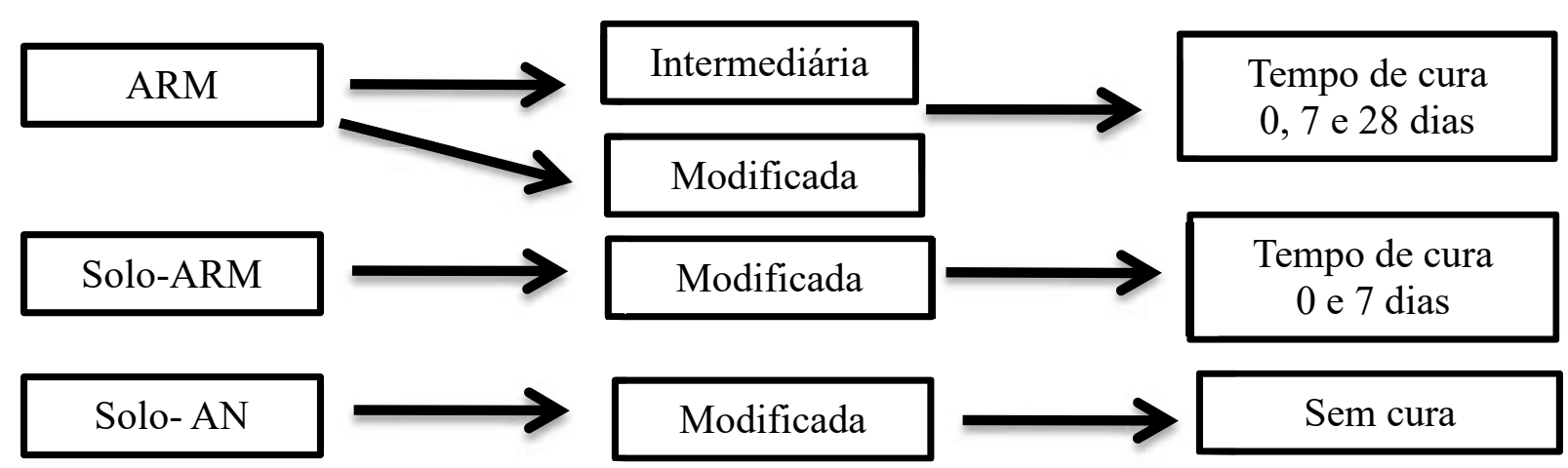

Figura 1: Programa experimental dos ensaios mecânicos complementares.

\subsection{MATERIAIS}

\subsubsection{Agregado reciclado misto (ARM)}

O agregado reciclado foi fornecido pela Usina de Reciclagem de Construção Civil AMX, localizada na Cidade de São Carlos-SP. A Figura 2 mostra o agregado reciclado produzido de acordo com a graduação. 


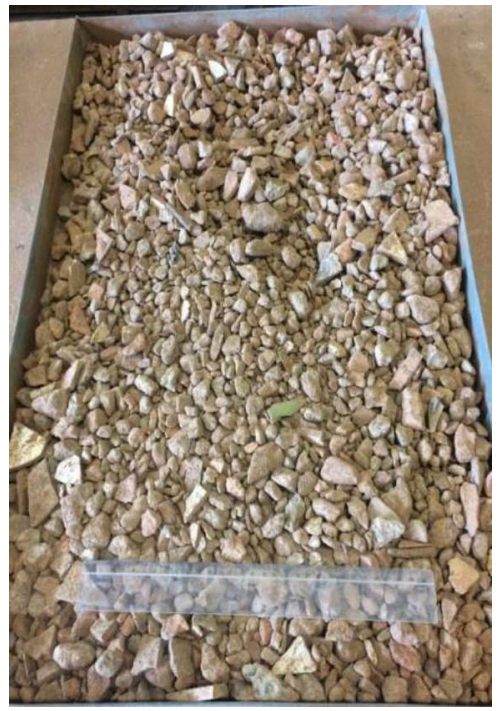

a) Pedra 1

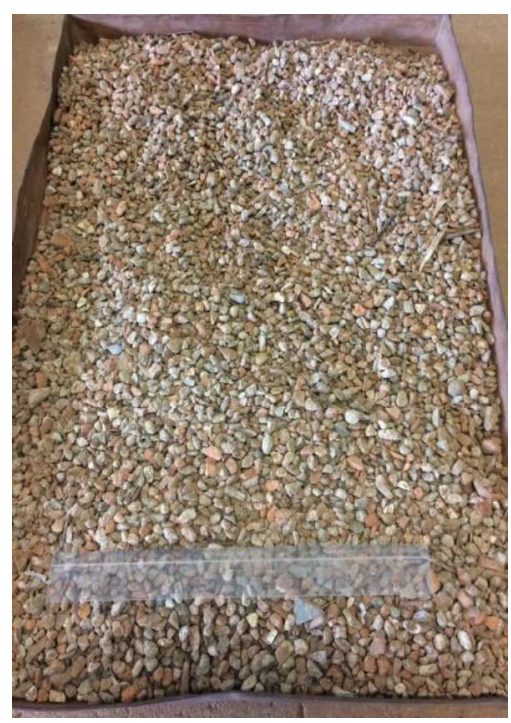

b) Pedrisco

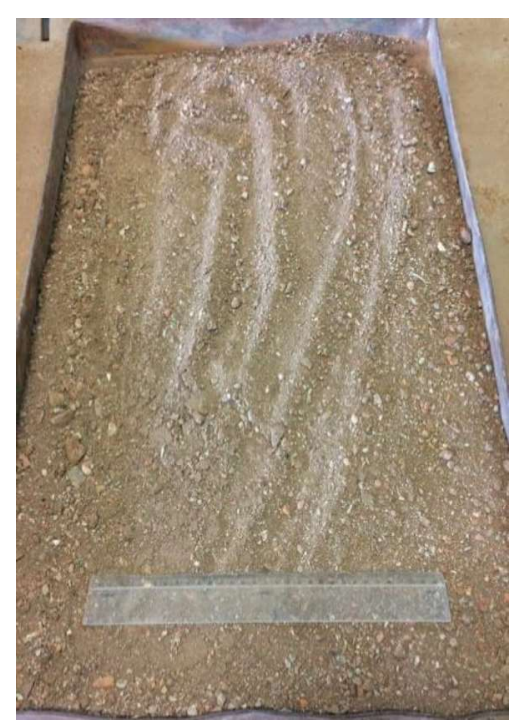

c) Areia

Figura 2: Agregado reciclado em diferentes granulometrias.

A coleta do ARM foi realizada de acordo com o procedimento DNER PRO 120/97, Coleta de amostra de agregados. Devido à possível variabilidade na composição do agregado, coletouse todo o material (cerca 1,5 toneladas) em um único dia, sendo 0,5 toneladas de cada uma das graduações: Pedra 1, Pedrisco e Areia.

Após a coleta o material foi transportado ao Laboratório de Estradas da EESC/USP, onde foi efetuada a secagem até a umidade higroscópica e reservado para a moldagem dos corpos de prova.

\subsubsection{Agregado natural (AN)}

O agregado natural foi fornecido pela Empresa Bandeirantes, localizada no município de São Carlos-SP, em duas graduações: Brita $1 / 2$ e Pedrisco. Os procedimentos de coleta foram semelhantes aos realizados para o ARM. Após a coleta, o agregado foi seco em estufa à temperatura de $110^{\circ} \mathrm{C}$.

\subsubsection{Solo}

O solo utilizado na mistura foi coletado no km 152+500m da Rodovia Luís Augusto de Oliveira (SP-215), em local próximo à cidade de São Carlos-SP. Após a coleta o solo foi homogeneizado, quarteado e seco ao sol até atingir a umidade higroscópica. 


\subsection{CARACTERIZAÇÃO E CLASSIFICAÇÃO DE MATERIAIS}

\subsubsection{Agregado reciclado misto (ARM)}

Atendendo às especificações da norma ABNT 15115/2004, a caracterização dos agregados foi realizada com base nos ensaios de granulometria por peneiramento, composição dos materiais constituintes e forma dos grãos. Complementarmente, foram realizados os ensaios de densidade aparente e absorção, abrasão Los Angeles e índice de degradação Proctor (IDp).

Ainda com relação à degradação, foram realizados adicionalmente ensaios de granulometrias por peneiramento após compactação, com o objetivo de observar mudanças na distribuição granulométrica decorrentes da quebra de agregados.

A análise granulométrica foi realizada segundo o descrito na norma NBR 7181/84 "SoloAnálise granulométrica”. Foram utilizadas as peneiras necessárias para enquadrar o material em uma das faixas granulométricas especificada pelo DNER ES 303/97, Pavimentação-base estabilizada granulometricamente.

A composição do agregado reciclado foi determinada por meio de catação e análise visual. Uma amostra, de aproximadamente $2,5 \mathrm{~kg}$ de material retido na peneira de $4,76 \mathrm{~mm}$, da fração Pedra 1 foi separada nos seguintes grupos: a) concreto/argamassa, b) brita (materiais britados), c) telha/tijolo (cerâmicos vermelhos), d) piso/azulejo, e) outros. Na figura 3, estão apresentados os materiais constituintes do ARM.

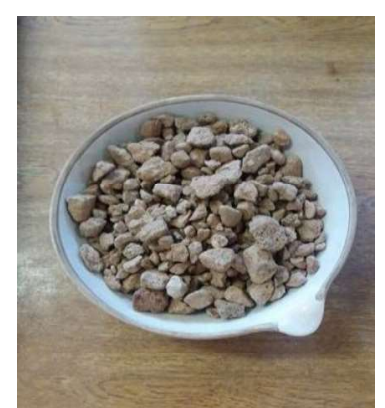

a) Concreto/argamassa

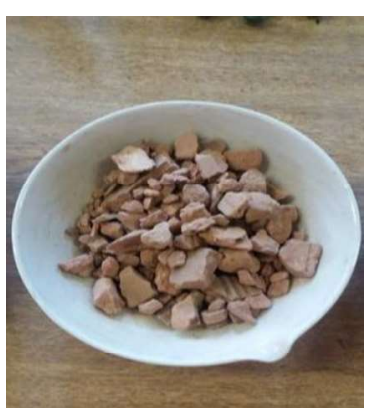

b) Telhas/tijolos 


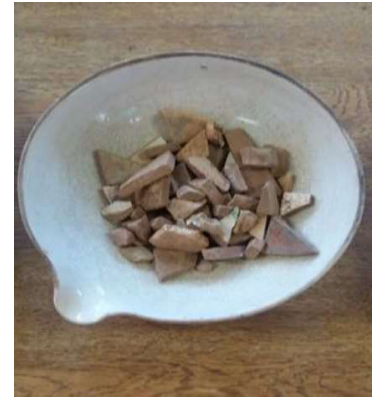

c) Cerâmica/azulejo

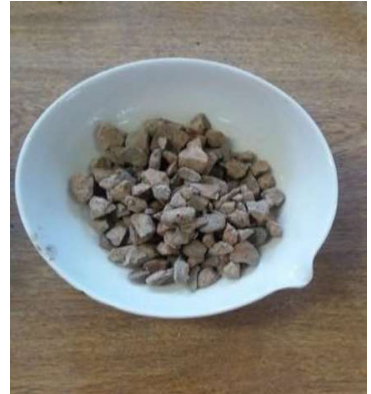

d) Brita

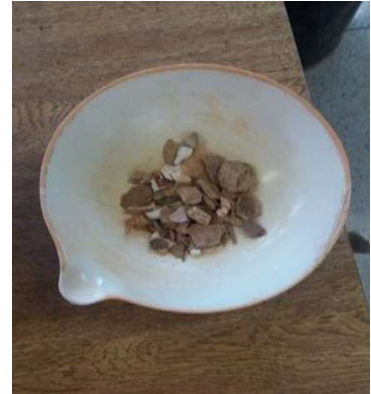

d) Outros

Figura 3: Materiais separados de acordo com a composição.

A norma utilizada para determinar a absorção e a densidade aparente do agregado graúdo (material retido na peneira 4,76 mm) foi a DNER-ME 081/98. Após secar o material em estufa, o mesmo foi imerso em água por 24 horas. A partir da massa do material seco em estuda e das massas saturada superfícialmente seca e imersa, é possível calcular a absorção de água do material. Na Figura 4, pode ser observado o material imerso em água.

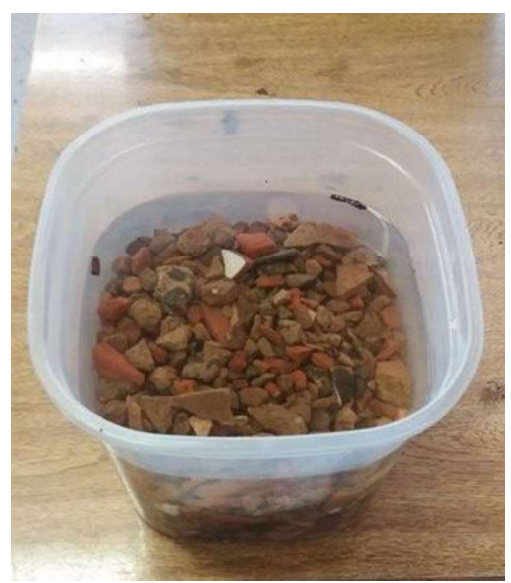

Figura 4: Material imerso em água por 24 horas.

O ensaio de abrasão Los Angeles foi realizado de acordo com a DNER-ME 035/98, utilizandose a graduação B da especificação. Na Figura 5, está apresentado o material retido e o material passante após do ensaio na peneira de 1,7 mm. 


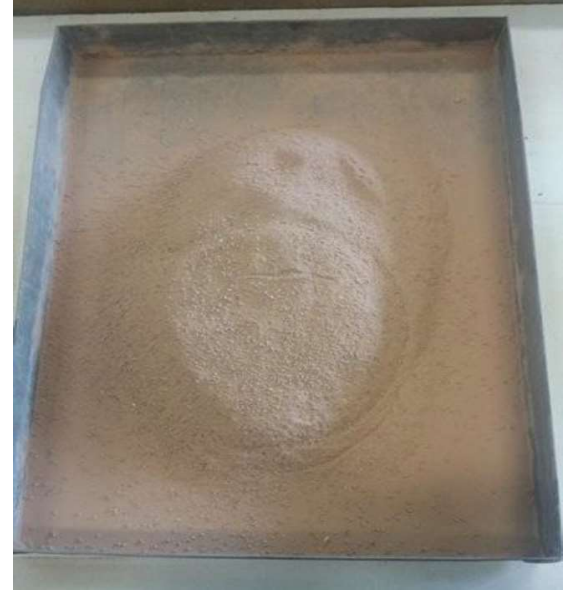

a) Material passante na $1,7 \mathrm{~mm}$.

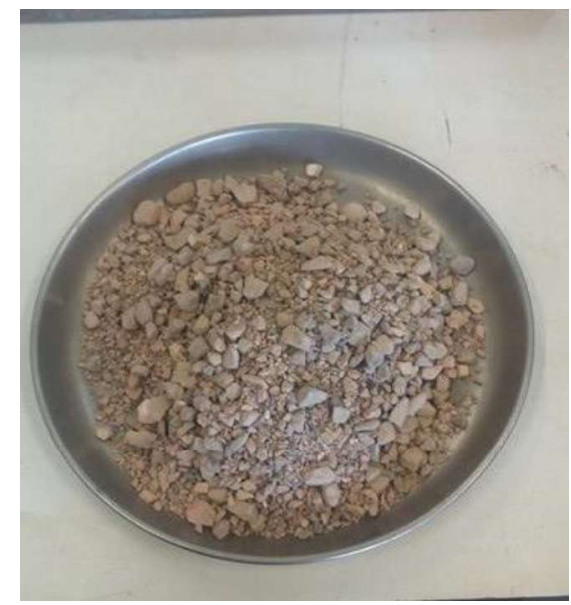

b) Material retido na $1,7 \mathrm{~mm}$.

Figura 5: Material passante e retido na peneira 1,7 $\mathrm{mm}$.

O ensaio de forma dos grãos foi realizado de acordo com a norma ABNT 7809/2006: Agregado graúdo-Determinação do Índice de Forma pelo Método do Paquímetro, Método, conforme recomendado pela ABNT 15115/2004. A forma dos grãos é obtida pela relação entre o comprimento e espessura do grão.

O ensaio de Índice de degradação após compactação Proctor, foi realizado conforme a norma DNER-ME 398/99. O índice de degradação é a relação entre o somatório das diferenças entre o passante em cada peneira antes e após a compactação (equivalente a energia intermediária), para uma faixa granulométrica padronizada, dividido pelo número de peneiras utilizadas (7).

\subsubsection{Agregado natural}

A fim de comparar suas características físicas do AN com as do ARM, foram realizados os seguintes ensaios de caracterização do agregado natural: a) granulometria por peneiramento, b) densidade aparente e absorção e c) abrasão Los Angeles.

\subsubsection{Solo}

O solo foi classificado de acordo com a classificação da Highway Research Board (HRB), por meio dos ensaios de análise granulométrica (NBR 7181/84), limite de liquidez (DNER-ME 122/94) e limite de plasticidade (DNER-ME 82/94). Além da classificação tradicional HRB, o solo foi classificado conforme a metodologia MCT. 


\subsection{COMPOSIÇÃO DAS MISTURAS}

\subsubsection{Composição da mistura ARM}

Uma vez que a norma de agregados reciclados (ABNT 15115/2004) não preconiza faixas granulométricas, as três frações granulométricas do agregado reciclado foram proporcionadas de modo a atender os requisitos da norma para estabilização granulométrica DNER ES 303/97. A distribuição granulométrica alvo foi centro da faixa $\mathrm{C}$ da norma, cuja característica é de uma mistura densa.

\subsubsection{Composição das misturas solo-ARM}

Como não existem recomendações de composição de misturas de solo-ARM, a composição da primeira mistura de solo-ARM foi feita tentando-se aproveitar ao máximo a mistura de ARM, e mantendo a mistura dentro de uma faixa granulométrica (faixa D). A mudança de faixa granulométrica foi inevitável, tendo em vista que o solo é mais fino que a fração fina do ARM.

A partir do resultado do ensaio de compactação dessa primeira mistura, foi feita uma segunda dosagem de solo-ARM, visando manter a quantidade de finos da mistura, sendo toda a fração fina do ARM substituída por solo. Similarmente, essa mistura solo-ARM enquadrou-se na faixa D.

\subsubsection{Composição das misturas solo- AN}

A composição da mistura de referência, solo- $\mathrm{AN}$, foi feita de modo a se enquadrar na faixa granulométrica C da norma DNER ES 303/97, mesma faixa granulométrica da mistura de ARM, utilizando as proporções de $30 \%$ de solo e $70 \%$ de AN.

\subsection{ENSAIOS DE COMPACTAÇÃO E DEGRADAÇÃO APÓS COMPACTAÇÃO}

Os ensaios de compactação das quatro misturas foram realizados de acordo com a norma NBR 7182/84, Solo-Ensaio de compactação, afim de determinar os valores de massa específica seca máxima e umidade ótima. Para o ARM e as misturas de solo-ARM, os ensaios de compactação foram realizados em duas energias de compactação: intermediária e modificada. Estas condições buscaram entender o efeito da energia de compactação nas propriedades das misturas com agregado reciclado, assim como observar a quebra do agregado por compactação. 
Para a mistura solo-AN foi utilizada apenas a energia modificada. Os ensaios foram realizados sem reaproveitamento de material e com substituição da fração retida na peneira de $19 \mathrm{~mm}$, por igual quantidade de material passante na peneira $19 \mathrm{~mm}$ e retido na peneira de $4,8 \mathrm{~mm}$.

Além do ensaio de índice de degradação Proctor, para o ARM foi feita a análise da distribuição granulométrica de amostras após a compactação por impacto (Proctor) e estática (prensa). Os CPs foram produzidos nas energias intermediária e modificada e nas condições de umidade ótima e massa específica seca máxima e foram realizados combinados à produção de CPs para os ensaios mecânicos. Após a compactação, foram comparadas as curvas após a compactação com a curva granulométrica antes da compactação.

Para as misturas de solo-ARM, os ensaios de degradação pós-compactação foram realizados em CPs compactados estaticamente na energia modificada, pois foi o método utilizado para a moldagem dos corpos de prova para os ensaios de RCS, RTCD e MR. Os CPs foram moldados nas condições de umidade ótima (tolerância de 0,5\%) e massa específica seca máxima (tolerância de 1\%) obtidos nos ensaios de Proctor.

\subsection{ENSAIOS DE COMPORTAMENTO MECÂNICOS DOS MATERIAIS}

\subsubsection{Ensaios de CBR e expansão}

O ensaio de CBR foi realizado conforme a norma DNER 049/94, simultaneamente aos ensaios de compactação. Após a compactação, os corpos de prova foram imersos em água por um período de quatro dias, ao longo dos quais foram feitas medidas da expansão do material. A penetração foi realizada por uma prensa de capacidade de $5000 \mathrm{~kg}$ a uma velocidade de penetração controlada de $1,27 \mathrm{~mm} / \mathrm{mim}$.

\subsubsection{Ensaio de resistência à compressão simples (RCS)}

Os ensaios de RCS foram realizados observando-se o prescrito pela norma DNER-ME 201/94 para misturas solo-cimento. Eles foram executados em uma prensa com capacidade de aplicação de carga de $1000 \mathrm{kgf}$, a uma velocidade de $1,27 \mathrm{~mm} / \mathrm{min}$. A partir dos valores da força máxima de compressão e as dimensões de cada corpo de prova, a RCS foi calculada pela Equação 1. 


$$
\mathrm{RCS}=\frac{4 \cdot \mathrm{F}}{\mathrm{g} \cdot \pi \cdot \mathrm{D}^{2}}
$$

Onde:

RCS: Resistência à compressão simples $\left[\mathrm{kgf} / \mathrm{cm}^{2}\right]$;

F: Força máxima de compressão [kgf];

g: Aceleração da gravidade adotada de $\left[9,81 \mathrm{~m} / \mathrm{s}^{2}\right]$;

D: Diâmetro do corpo de prova [cm].

\subsubsection{Ensaio de resistência à tração por compressão diametral}

Os ensaios de resistência à tração foram executados, segundo a norma DNER-ME 138/94, em uma prensa com capacidade de aplicação de carga de $1000 \mathrm{kgf}$, a uma velocidade de 1,27 $\mathrm{mm} / \mathrm{min}$.

O valor da RTCD é calculado a partir da relação entre a força de ruptura e as características geométricas dos corpos de prova. Este parâmetro pode ser calculado pela equação 3.

$$
\mathrm{RCTD}=\left(\frac{2 \times \mathrm{F}}{\pi \times \mathrm{D} \times \mathrm{H}}\right)
$$

Onde:

$\mathrm{RTCD}=$ Resistência à tração por compressão diametral $\left[\mathrm{kgf} / \mathrm{cm}^{2}\right]$;

$\mathrm{F}=$ Carga de ruptura [kgf];

$\mathrm{D}=$ Diâmetro do corpo-de-prova $[\mathrm{cm}]$;

$\mathrm{H}=$ Altura do corpo-de-prova $[\mathrm{cm}]$.

\subsubsection{Ensaio triaxial cíclico}

O ensaio de módulo de resiliência foi realizado segundo a norma AASHTO T 307-99 Standard Method of Test for Determining the Resilient Modulus of Soils and Aggregate Materials.

Os ensaios compõem-se de uma fase de condicionamento onde são aplicadas de 500 a 1.000 ciclos de carregamento, compostos por um par de tensões (desvio e confinante) e, em seguida, o ensaio propriamente dito é realizado. São impostos 15 pares de tensões, com aplicação de 100 ciclos. Na Tabela 4 são mostrados os pares de tensões recomendados para realização do ensaio para a determinação do módulo de resiliência. 
Tabela 4: Pares de tensões aplicados no ensaio de MR.

\begin{tabular}{cccc}
\hline Sequência & $\sigma 3[\mathrm{kPa}]$ & $\sigma \mathrm{d}[\mathrm{kPa}]$ & Número de aplicações \\
\hline 0 & 103,4 & 93,1 & $500-1000$ \\
1 & 20,7 & 78,6 & 100 \\
2 & 20,7 & 37,3 & 100 \\
3 & 20,7 & 55,9 & 100 \\
4 & 34,5 & 31 & 100 \\
5 & 34,5 & 62 & 100 \\
6 & 34,5 & 93,1 & 100 \\
7 & 68,9 & 62 & 100 \\
8 & 68,9 & 124,1 & 100 \\
9 & 68,9 & 186,1 & 100 \\
10 & 103,4 & 62 & 100 \\
11 & 103,4 & 93,1 & 100 \\
12 & 103,4 & 196,1 & 100 \\
13 & 137,9 & 93,1 & 100 \\
14 & 137,9 & 124,1 & 100 \\
15 & 137,9 & 248,2 & 100 \\
\hline
\end{tabular}

Os ensaios foram executados em um equipamento triaxial de cargas repetidas dotado de uma célula de carga com capacidade de 10 kN. Dois LVDT's (Linear Variable Differential Transducers) foram posicionados no terço médio dos corpos de prova, com o objetivo de medir os deslocamentos sofridos pelo corpo de prova durante o ensaio.

Durante a realização do ensaio, a aquisição dos dados referentes às cargas e aos deslocamentos foi realizada por um programa computacional, desenvolvido pelo Prof. Dr. Glauco Tulio Pessa Fabbri. O programa ajusta os dados do ensaio a quatro modelos matemáticos que representam o MR (Tabela 5). O modelo com maior coeficiente de determinação $\left(\mathrm{R}^{2}\right)$ foi selecionado como o representativo do MR do material. 
Tabela 5: Modelos matemáticos para cálculo do MR.

\begin{tabular}{lc}
\hline \multicolumn{1}{c}{ Modelo } & Equação \\
\hline Modelo em função da tensão desvio & $\mathrm{MR}=\mathrm{k}_{1} \cdot \sigma_{\mathrm{d}}^{\mathrm{k}_{2}}$ \\
Modelo em função da tensão confinante & $\mathrm{MR}=\mathrm{k}_{1} \cdot \sigma_{3}^{\mathrm{k}_{2}}$ \\
Modelo composto & $\mathrm{MR}=\mathrm{k}_{1} \cdot \sigma_{3}^{\mathrm{k}_{2}} \cdot \sigma_{\mathrm{d}}^{\mathrm{k}_{3}}$ \\
Modelo universal - AASHTO & $\mathrm{MR}=\mathrm{k}_{1} \cdot \mathrm{p}_{\mathrm{a}} \cdot\left(\frac{\theta}{\mathrm{p}_{\mathrm{a}}}\right)^{\mathrm{k}_{2}} \cdot\left(\frac{\tau_{\text {oct }}}{\mathrm{p}_{\mathrm{a}}}+1\right)^{\mathrm{k}_{3}}$ \\
\hline
\end{tabular}

Onde:

$\mathrm{k}_{\mathrm{i}}=$ constantes de regressão múltipla;

$\sigma_{\mathrm{d}}=$ tensão desvio;

$\sigma_{3}=$ tensão confinante;

$\mathrm{p}_{\mathrm{a}}=$ pressão atmosférica;

$\theta=$ somas das três tensões principais

$\tau_{\text {oct }}=$ tensão octaédrica cisalhante.

Visando apresentar uma aplicação prática e facilitar a comparação dos resultados, foram calculadas as tensões atuantes em uma estrutura de pavimento de baixo volume de tráfego e o valor de MR da camada de base. A estrutura do pavimento e as características dos materiais são apresentadas na Tabela 6 .

Tabela 6: Estrutura do pavimento hipotético.

\begin{tabular}{lccc}
\hline Camada & $\begin{array}{c}\text { Espessura } \\
{[\mathbf{c m}]}\end{array}$ & $\begin{array}{c}\text { Coeficiente de } \\
\text { Poisson }[\mathbf{v}]\end{array}$ & MR [MPa] \\
\hline Tratamento Superficial & 2,5 & 0,30 & 1500 \\
Base & 15,0 & 0,35 & Variável* \\
Sub-base & 15,0 & 0,35 & 90 \\
Subleito & Semi-infinito & 0,40 & 45
\end{tabular}


Essa estrutura representa um pavimento para baixo volume de tráfego. As espessuras das camadas, o coeficiente de Poisson (v) e o módulo de resiliência (MR) dos materiais foram baseados nos indicados pela instrução de projeto IP-DE-P00-001/2006 do DER de São Paulo.

\subsubsection{Moldagem dos corpos de prova}

Os corpos de prova para os ensaios mecânicos foram moldados numa prensa de compactação estática, nas condições de umidade ótima e massa específica seca máxima. Para isso, foi adicionada água suficiente para atingir a umidade desejada, então o material foi homogeneizado e colocados em saco plástico, por 24 h, para uniformização da umidade.

As dimensões dos CPs empregados nos ensaios de RCS e MR foram de $10 \mathrm{~cm}$ de diâmetro por $20 \mathrm{~cm}$ de altura, moldados em 5 camadas. Já as dimensões CPs para os ensaios de RTCD foram de $10 \mathrm{~cm}$ de diâmetro e $8 \mathrm{~cm}$ de altura, moldados em uma única camada. Os CPs a serem rompidos com cura, foram embalados e armazenados em câmera úmida, de modo a conservar a umidade.

Para os ensaios de RCS e RTCD foram moldados 3 CPs por condição experimental e para o ensaio de MR, foi moldado $1 \mathrm{CP}$.

\subsubsection{Tratamento estatístico}

Para a identificação de outliers das amostras, foi aplicada na análise estatística dos resultados o teste de Grubbs, desenvolvido em 1969.

Nesse teste, são usados os valores da média aritmética e do desvio padrão de cada grupo de amostras na determinação de um valor estatístico $(\mathrm{G})$, calculado pela Equação 2 apresentada a seguir.

$$
\mathrm{G}=\max \left(\frac{\mathrm{Y}_{\mathrm{i}}-\overline{\mathrm{Y}}}{\mathrm{S}}\right)
$$

Onde:

$\mathrm{Y}_{\mathrm{i}}$ : é uma observação da amostra;

$\bar{Y}$ : é a média amostral;

s: desvio padrão amostral. 
Uma observação é considerada outlier, se o valor estatístico $\mathrm{G}$ for maior que o valor crítico $\mathrm{G}_{\mathrm{c}}$, que depende do nível de confiança e do número de observações da amostra. Para este trabalho adotou-se $\mathrm{G}_{\mathrm{c}}=1,15$, uma vez que foram feitas 3 observações e o nível de confiança é de 95\%. Quando $\mathrm{G}>\mathrm{G}_{\mathrm{c}}$ o resultado é considerado outlier e por isso, é descartado.

Todos os resultados referentes aos ensaios de RCS, RTCD e MR, estão apresentados de forma detalhada nos apêndices A, B e C, respectivamente. 


\section{APRESENTAÇÃO E DISCUSSÃO DOS RESULTADOS}

Neste capítulo são apresentados e discutidos os resultados dos ensaios de caracterização dos materiais e de estabilização granulométrica das misturas de ARM, solo-ARM e solo- AN. Assim como, os resultados dos ensaios de compactação, CBR, RCS, RTCD e MR dos materiais estudados nesta pesquisa.

\subsection{CARACTERIZAÇÃO FÍSICA DOS MATERIAIS}

\subsubsection{Agregados}

Na Figura 6, são apresentadas as curvas granulométricas obtidas das três frações de agregado reciclado: Pedra1, Pedrisco e Areia, onde se pode notar que as frações Pedra 1 e Pedrisco apresentam praticamente paralelas. Além disso, a curva granulométrica do Pedrisco apresenta baixa porcentagem passada na peneira de abertura $4,76 \mathrm{~mm}$. Nota-se ainda que há uma lacuna entre as curvas de Pedrisco e Areia. Essas particularidades granulométricas das frações do agregado reciclado podem dificultar o processo de proporcionamento e as misturas podem resultar em faixas descontínuas.

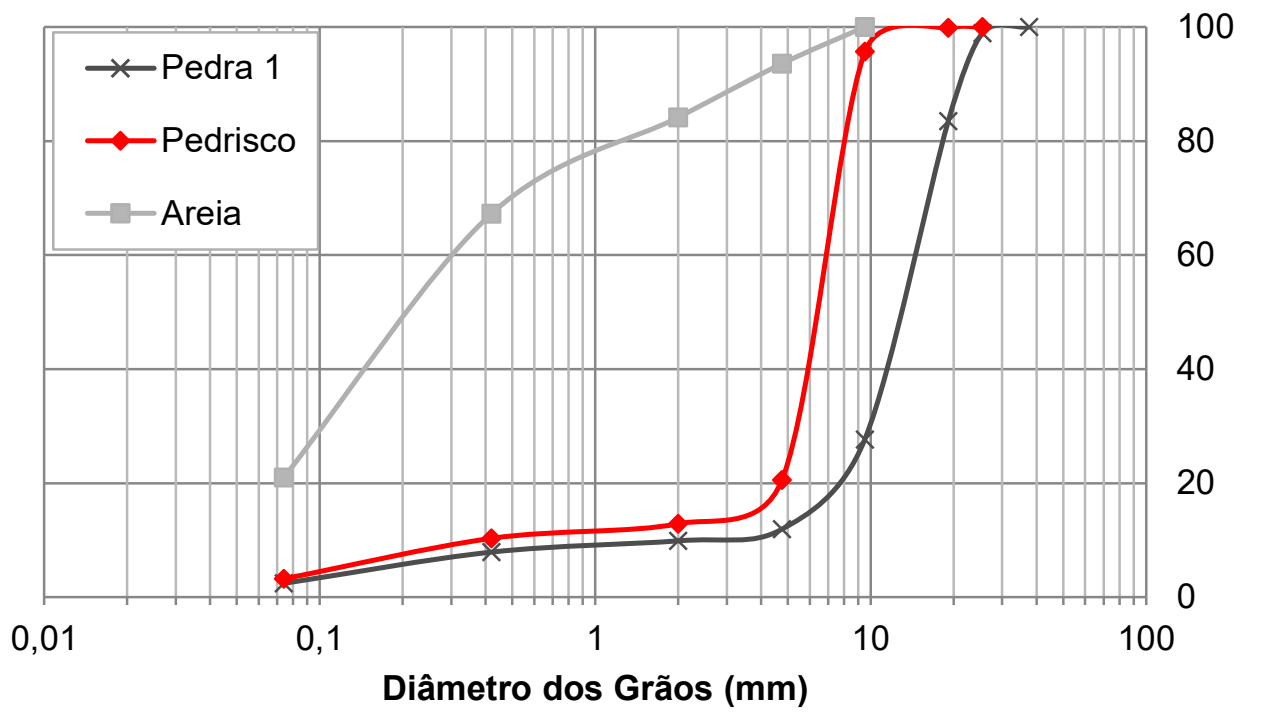

Figura 6: Curva granulométrica das frações do ARM. 
No que se refere a distribuição granulométrica para as duas frações de agregado natural: Pedra $1 / 2$ e Pedrisco, os resultados são apresentados na Figura 7. É possível observar que há também uma lacuna entre as duas frações, o que pode, assim como para o ARM, dificultar o processo de enquadramento.

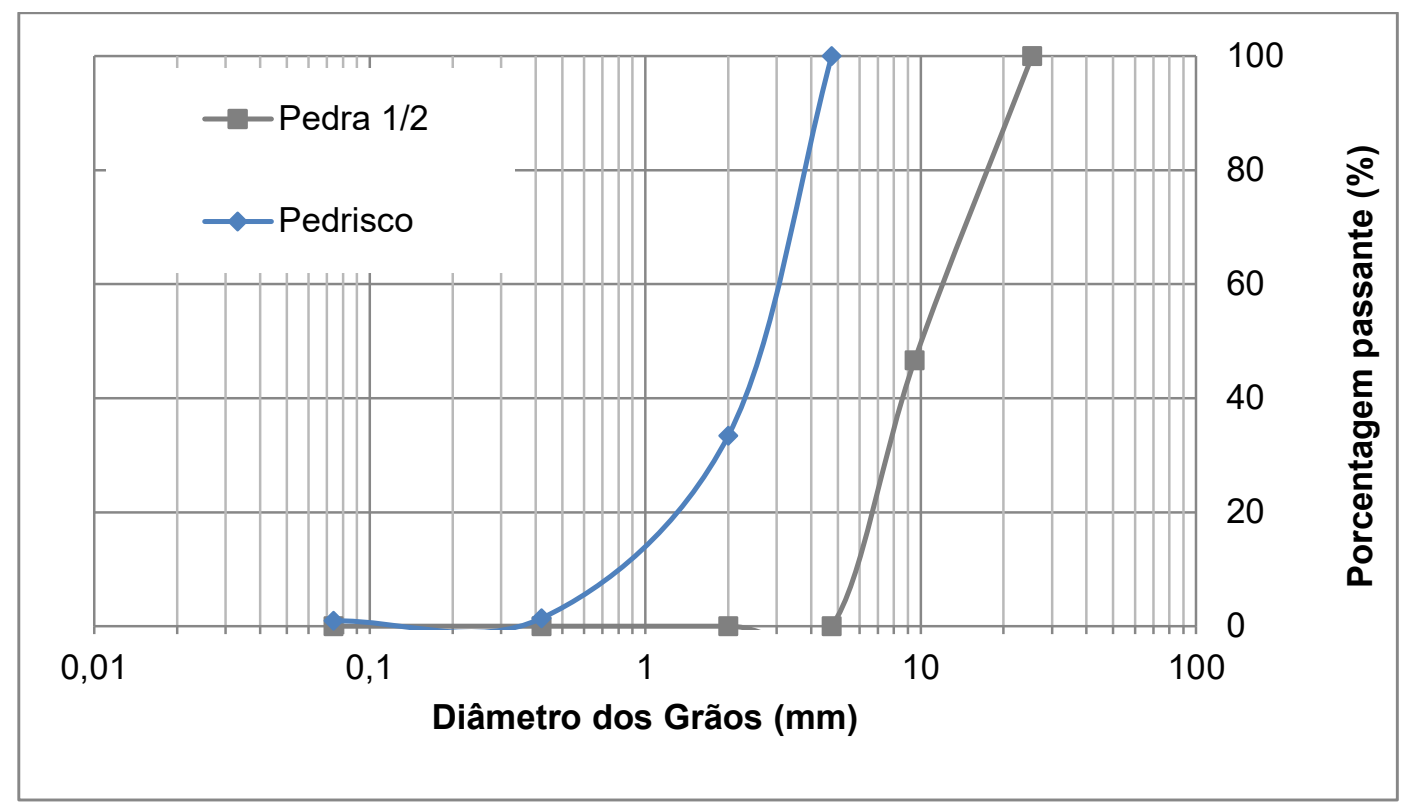

Figura 7: Curva granulométrica das frações do AN.

No que se refere à composição do ARM, a composição dos materiais constituintes é apresentada na Figura 8. Pode-se perceber que aproximadamente metade da fração graúda do ARM é composta por concreto. Já a porcentagem de materiais indesejáveis é pequena, sendo menor do que o recomendado pela norma.

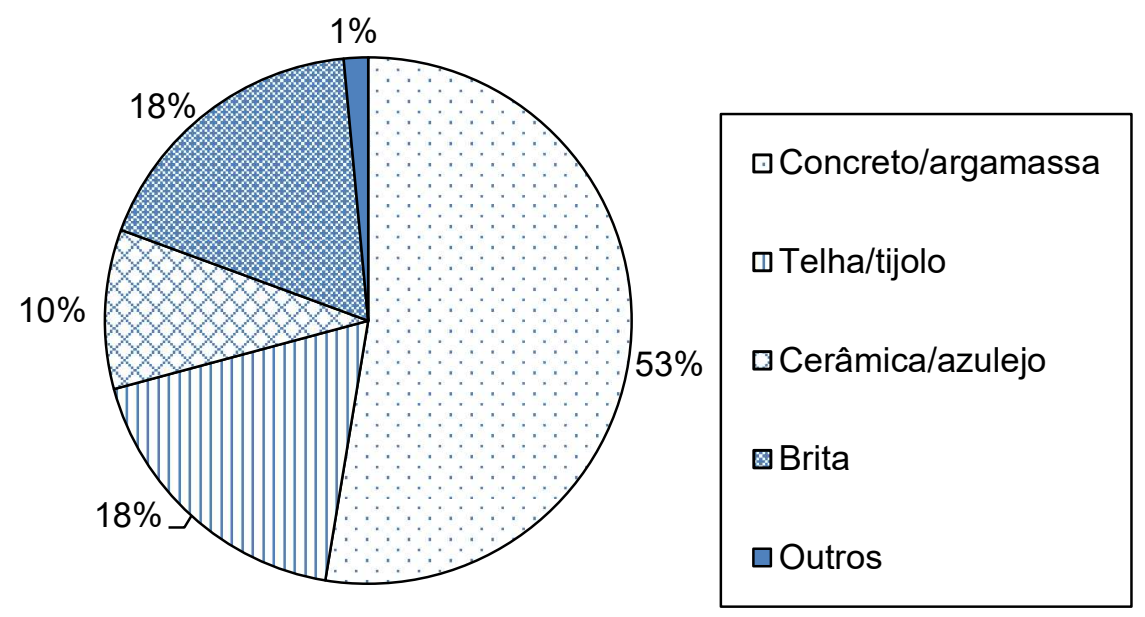

Figura 8: Composição do agregado reciclado. 
As demais características físicas do ARM em comparação com o agregado natural são apresentadas na Tabela 7.

Tabela 7: Caracterização física dos agregados.

\begin{tabular}{lcc}
\hline Características físicas & ARM & AN \\
\hline Abrasão Los Angeles (\%) & 51 & 19 \\
Densidade aparente do agregado graúdo $\left(\mathrm{g} / \mathrm{cm}^{3}\right)$ & 2,075 & 2,783 \\
Absorção do agregado graúdo (\%) & 9,74 & 2,2 \\
Grãos lamelares da fração graúda (\%) & 23 & - \\
Índice de degradação (\%) & 8,8 & - \\
\hline
\end{tabular}

Analisando-se a Tabela 7, constata-se que o agregado reciclado apresentou um valor de Abrasão Los Angeles de $51 \%$, este valor é maior que o apresentado para agregado natural que apresentou um valor de 19\%. Quando analisado pela norma DNER-ES 303/97 o material o agregado atende o limite que é de $55 \%$.

Quanto a densidade aparente do agregado graúdo do ARM, verifica-se que a densidade do agregado reciclado $2,075 \mathrm{~g} / \mathrm{cm}^{3}$ é inferior ao valor encontrado para o $\mathrm{AN}$, que no caso foi de $2,783 \mathrm{~g} / \mathrm{cm}^{3}$.

No tocante à absorção de água da fração graúda, verifica-se que o valor encontrado nesta pesquisa, 9,74 \%. Esse valor se aproxima dos encontrados por Motta (2005) e Leite (2007), que obtiveram os valores de 7,8 \% e 12,2\% respectivamente. Além disso, observa-se que é um valor superior ao obtido pelo $\mathrm{AN}$, que apresentou um valor de $2,2 \%$.

No que se refere aos grãos lamelares do ARM, obteve-se que estes representam $23 \%$ da amostra, atendendo o recomendado pela ABNT 15115/2004.

O índice de degradação após compactação Proctor, do ARM foi de 9,6 e do ARM com 5\% de solo passando na peneira $0,074 \mathrm{~mm}$ foi de 8,1 . Os valores, estão de acordo com os obtidos por Oliveira (2007) que obteve um IDp de 8,6 para misturas compostas exclusivamente por ARM e sinalizam que deve ser prestada atenção a degradação do material.

\subsubsection{Solo}

O solo utilizado apresenta as características apresentadas na Tabela 8. Assim, pôde ser classificado de acordo com a HRB como um solo A-2-6. 
A caracterização e classificação do solo concordam com as obtidas por Kakuda (2010) e Wallace (2011), permitindo concluir que se trata do mesmo solo, cuja classificação MCT foi LA', ou seja, é um solo arenoso laterítico.

Tabela 8: Caracterização física do solo.

\begin{tabular}{lc}
\hline Características & Resultados \\
\hline Limite de liquidez & 32 \\
Limite de Plasticidade & 18 \\
Índice de Plasticidade & 13 \\
\%Passante na \#200 & 30 \\
\hline
\end{tabular}

Observa-se que o solo possui granulometria mais fina que a fração areia do ARM, assim ao adicionar solo ao ARM ou substituir toda a fração fina do ARM por solo, a curva resultante será mais fina que aquela composta exclusivamente com ARM.

\subsection{COMPOSIÇÃO DAS MISTURAS}

\subsubsection{Composição da mistura de ARM}

Após uma série de tentativas, conseguiu-se enquadrar a mistura composta exclusivamente por ARM na faixa C da norma DNER ES 303/97, adicionando-se 1/3 de cada fração granulométrica. Na Figura 9, é apresentada a curva obtida pela composição dos agregados.

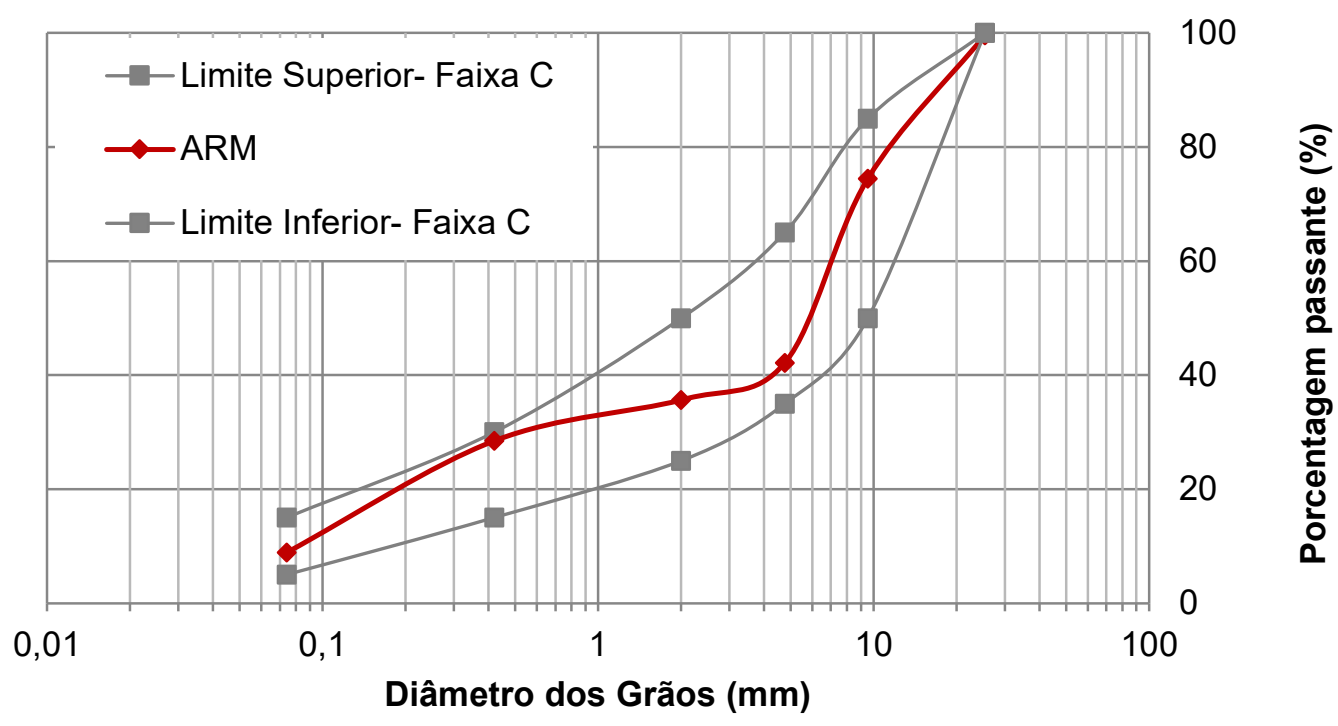

Figura 9: Curva granulométrica da composição do ARM. 
Observa-se que a curva de ARM tem problemas de descontinuidade na peneira 9,52 mm, mas se enquadra na Faixa C. Essa lacuna da fração intermediária pode dificultar o entrosamento das partículas durante o processo de compactação.

Quanto às características físicas do ARM recomendadas pela ABNT 15115/2004, foram obtidos os resultados apresentados na Tabela 9. Observa-se que os parâmetros obtidos atendem o recomendado pela norma por isso podem ser empregados como material em base e sub-base de pavimentos.

Tabela 9: Características do agregado reciclado.

\begin{tabular}{lcc}
\hline Parâmetro & Resultado & Limites da ABNT \\
\hline Dimensão máxima característica $(\mathrm{mm})$ & 25,4 & 63,5 \\
\% passante na peneira 0,42 mm & 28 & 10 a 40 \\
Coeficiente de uniformidade & 87 & $\geq 10$ \\
Grãos lamelares da fração graúda $(4,8 \mathrm{~mm})$ & 23 & $\leq 30 \%$ \\
Materiais indesejáveis (\%) & 1 & 2 a $3 \%$ \\
\hline * No presente trabalho a quantidade de materiais indesejáveis obtida refere-se apenas a fração graúda do ARM.
\end{tabular}

\subsubsection{Composição das misturas de solo-ARM}

A estabilização granulométrica da primeira mistura solo-ARM foi feita tentando-se aproveitar o máximo possível de ARM. Optou-se por manter a proporção de $1 / 3$ de cada fração de agregados, adicionando-se $15 \%$ de solo. A curva resultante está apresentada na Figura 10 Observa-se que a curva granulométrica da mistura se enquadra na faixa D da norma DNER ES 303/97.

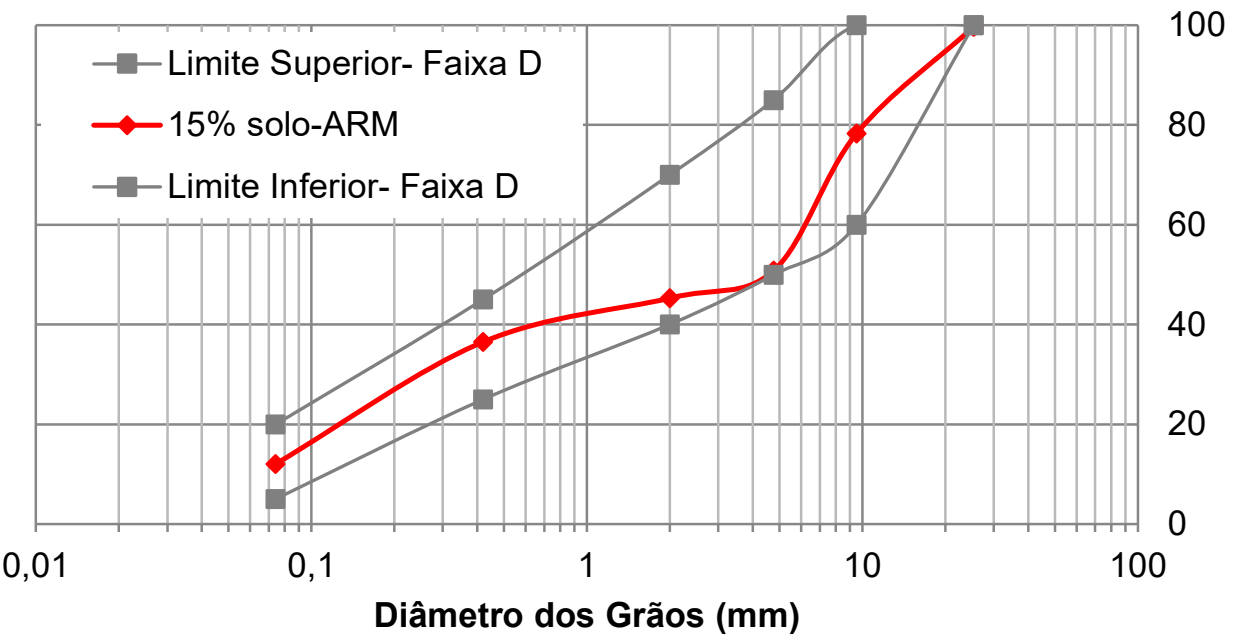

Figura 10: Curva granulométrica da composição 15\% solo-ARM. 
Na segunda mistura solo-ARM, procurou-se manter a mesma faixa granulométrica da mistura 15\% solo- ARM, utilizando na composição os materiais Pedra 1, Pedrisco e solo. O resultado da dosagem está apresentado na Figura 11, onde as proporções utilizadas foram de $20 \%$ de Pedra $1,35 \%$ de Pedrisco e $45 \%$ de solo.

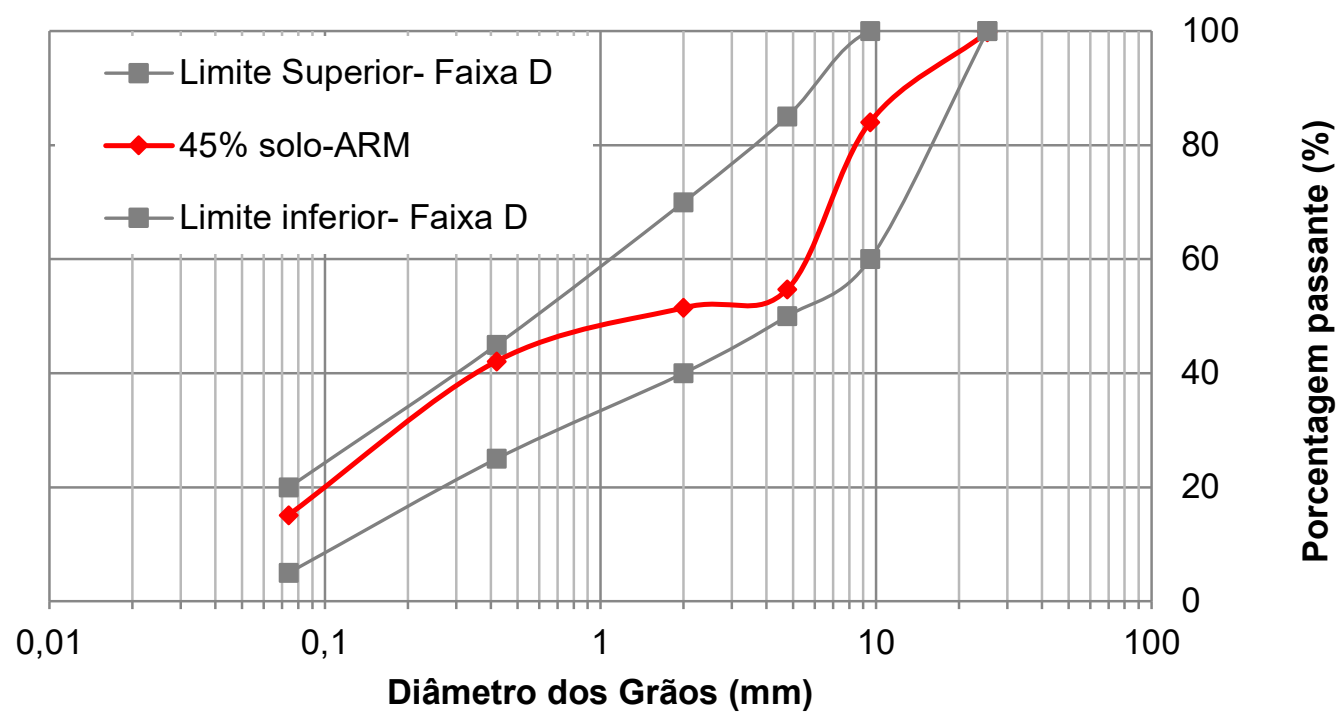

Figura 11: Curva granulométrica da composição 45\% solo-ARM.

Observa-se que as curvas granulométricas das misturas 15\% solo-ARM e 45\% solo ARM, estão enquadradas na mesma faixa granulométrica. Isso porque na mistura $15 \%$ solo-ARM há $1 / 3$ da fração Areia na composição de agregados. Já a mistura 45\% solo-ARM, não tem a fração Areia como agregado. Apesar da mistura com $45 \%$ de solo ser um pouco mais fina (o solo é mais fino que a areia), optou-se por usar $45 \%$ de solo, pois a mistura ficou mais centralizada na faixa $\mathrm{D}$, devido a maior porcentagem passante do solo nas peneiras $0,074 \mathrm{~mm}$ e $0,42 \mathrm{~mm}$ do que a fração areia.

\subsubsection{Composição da mistura de solo- AN}

A curva granulométrica obtida para a mistura solo-AN, composta por $30 \%$ de solo e $70 \%$ de AN, está apresentada na Figura 12. Além de ser um enquadramento bastante aplicado (30/70), a escolha por esta dosagem também foi motivada pelo fato dessa mistura estar enquadrada na faixa C da norma DNER-ES 303/97, mesma faixa da mistura de ARM. 


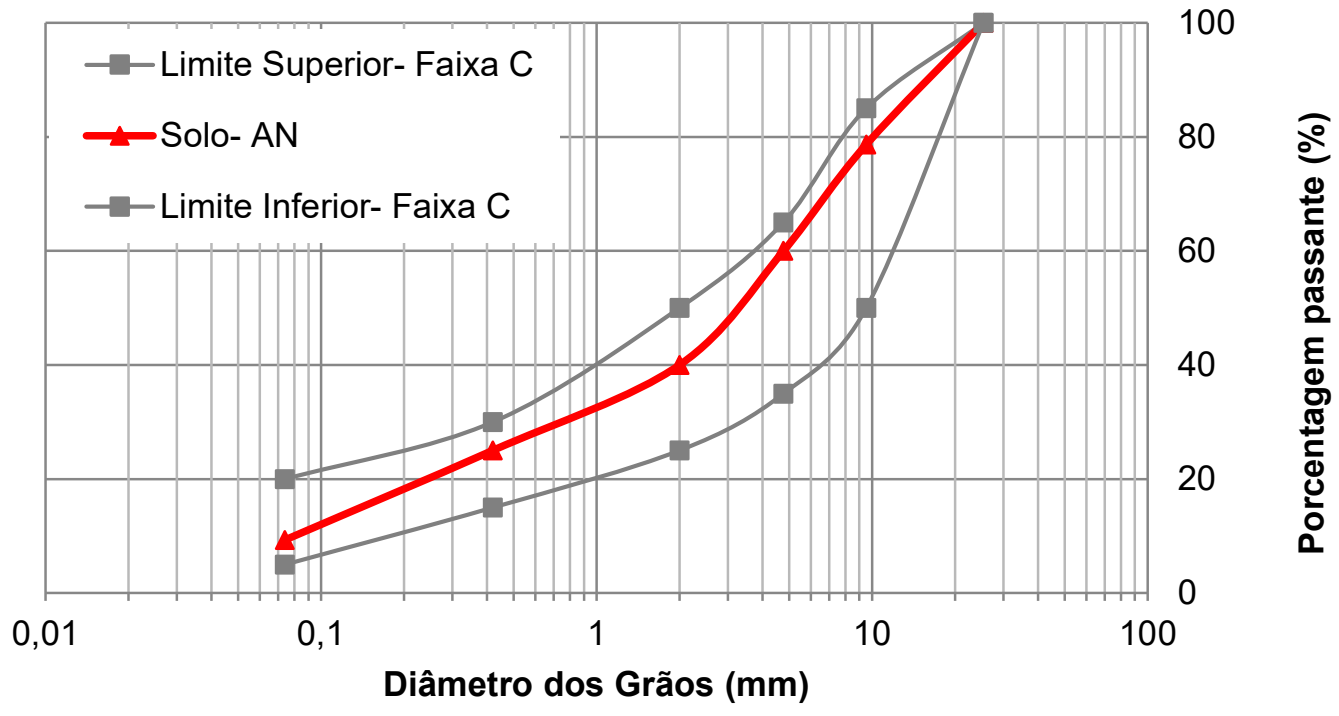

Figura 12: Curva granulométrica da composição solo-AN.

\subsection{ENSAIOS DE COMPACTAÇÃO}

\subsubsection{Ensaios de compactação do ARM}

Os ensaios de compactação do agregado reciclado foram realizados nas energias intermediária e modificada. Na Figura 13 são ilustrados os resultados obtidos.

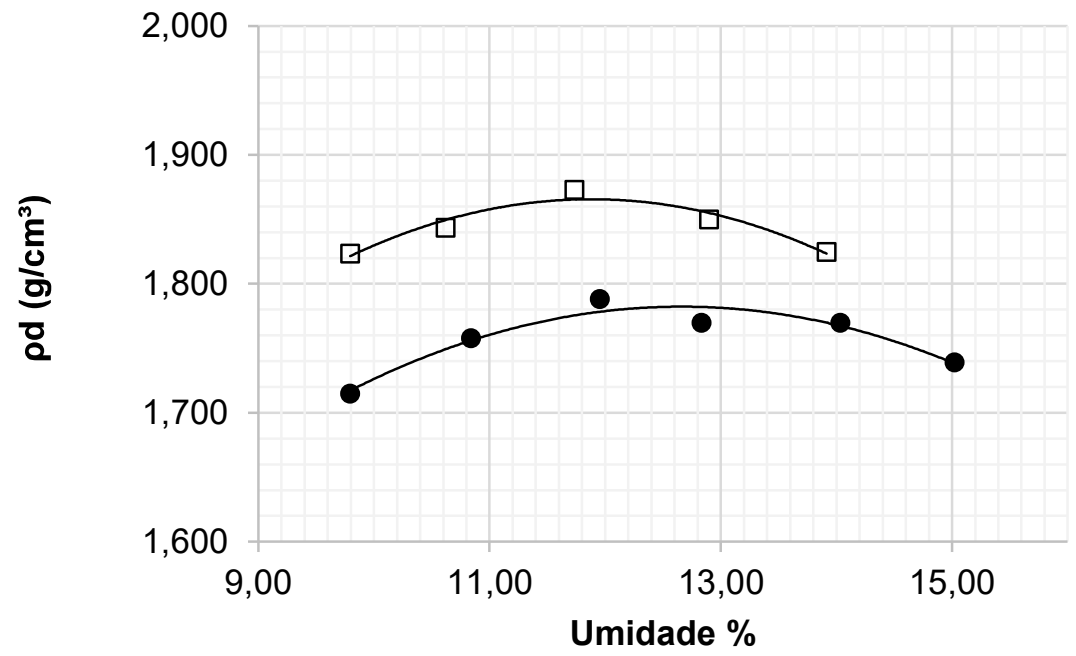

•E. Intermediária 口E. Modificada

Figura 13: Ensaios de compactação do ARM. 
Analisando-se a Figura 12, verifica-se que a energia de compactação teve influência nos valores de massa específica seca máxima e na umidade ótima do agregado reciclado. Foram obtidas massas específicas aparente secas máximas 1,782 e 1,866 g/ $\mathrm{cm}^{3}$ e umidades ótimas de 12,6\% e $11,8 \%$ para as energias intermediária e modificada, respectivamente. Assim, a curva de compactação obtida para energia modificada apresenta massa específica seca máxima maior e umidade ótima menor em relação à energia intermediária. Os valores estão de acordo com os obtidos por Leite et al. (2011), que encontraram valores de $\rho d$ máx de $1,760 \mathrm{~g} / \mathrm{cm}^{3}$ e 1,820 e Wótima de 14,6 \% e 13,5\%, para as energias intermediária e modificada, respectivamente.

\subsubsection{Ensaio de compactação das misturas solo-ARM}

Os ensaios de compactação da mistura 15\% solo-ARM foram realizados na energia intermediária e modificada. Na Figura 14, são ilustrados os resultados obtidos.

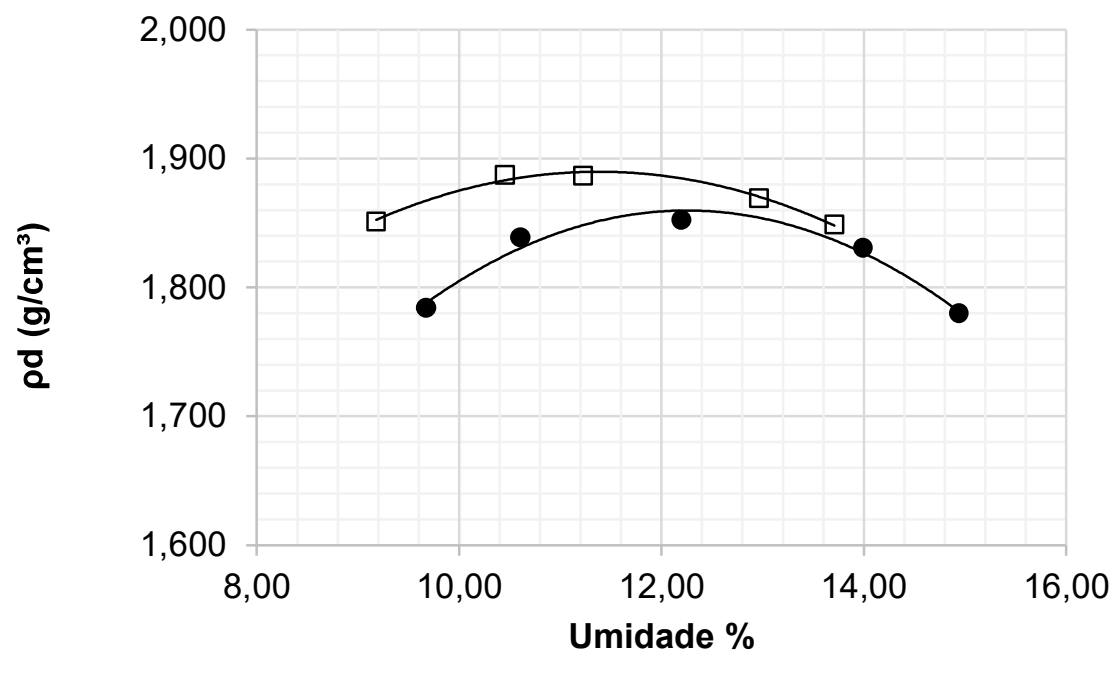

- E. Intermediária $\square$ E. Modificada

Figura 14: Ensaios de compactação 15\% solo-ARM.

Verifica-se que foram obtidas massas específicas aparente secas máximas de $1,860 \mathrm{~g} / \mathrm{cm}^{3} \mathrm{e}$ $1,890 \mathrm{~g} / \mathrm{cm}^{3}$ e umidades ótimas de 12,2\% e 11,4\% para as energias intermediária e modificada, respectivamente. $\mathrm{O}$ aumento da energia de compactação provocou um aumento na massa específica aparente seca máxima e diminuição no valor de umidade ótima do material, como ocorreu com o ARM sem adição de solo.

Para a mistura 45\% solo-ARM, os resultados dos ensaios de compactação estão apresentados na Figura 15. 


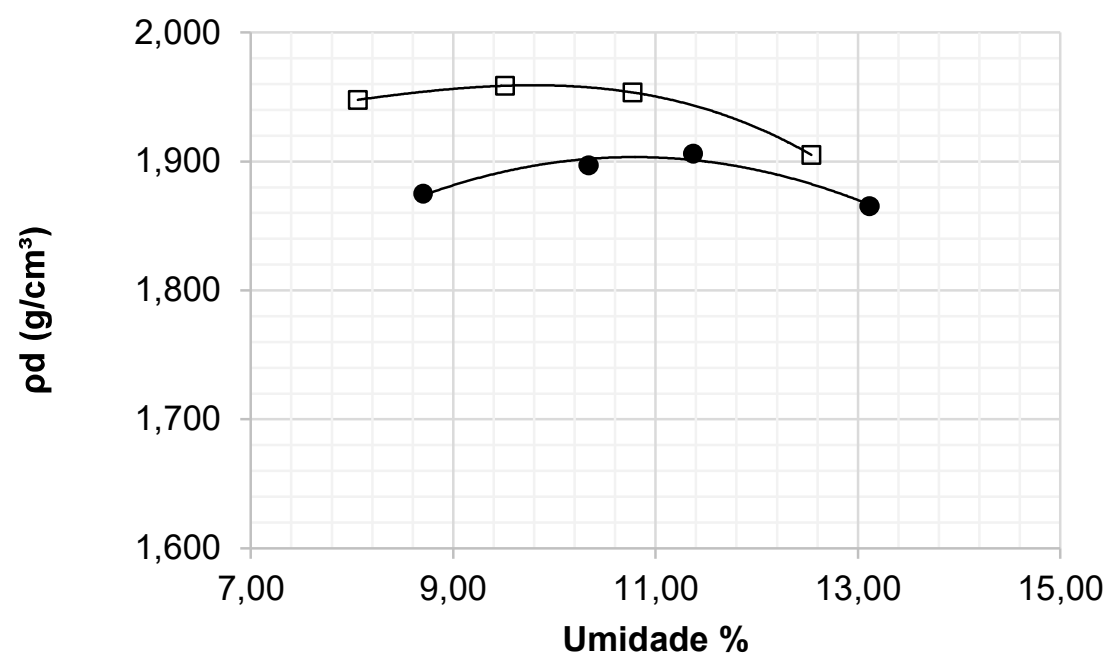

๑E. intermediária 口E. Modificada

Figura 15: Ensaio de compactação 45\% Solo-ARM.

Analisando-se a figura 15, verifica-se que foram obtidas massas específicas aparente secas máximas de $1,904 \mathrm{~g} / \mathrm{cm}^{3}$ e $1,960 \mathrm{~g} / \mathrm{cm}^{3}$ e umidades ótimas de $11,0 \%$ e $10,0 \%$ para as energias intermediária e modificada, respectivamente. $\mathrm{O}$ aumento da energia de compactação provocou um aumento na massa especifica aparente seca máxima e diminuição no valor de umidade ótima do material, como ocorreu com o ARM sem adição de solo e 15\% solo-ARM.

Pode-se observar ainda que quanto maior a porcentagem de solo, maior é a massa específica e menor a umidade ótima da mistura.

\subsubsection{Ensaios de compactação do solo-AN}

O ensaio de compactação do solo-AN foi realizado na energia modificada. Na Figura 16, é mostrado o resultado obtido, onde se observa que a massa específica aparente seca máxima é de $2,350 \mathrm{~g} / \mathrm{cm}^{3}$ e a umidade ótima $6,5 \%$ para a energia modificada. O elevado valor de massa específica aparente seca máxima e a baixa umidade da mistura quando comparados com as misturas com ARM, ocorre devido à menor absorção de água e elevada densidade do agregado natural em relação ao ARM. 


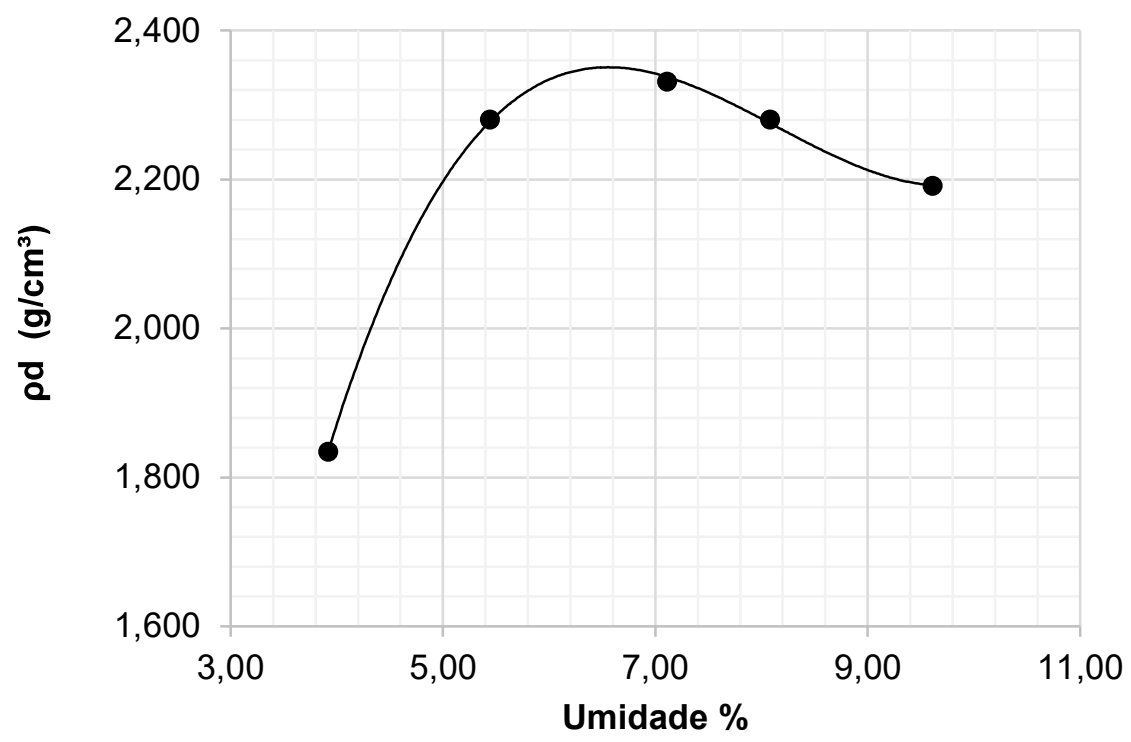

Figura 16: Ensaio de compactação do solo -AN na energia modificada.

Em resumo, os resultados dos ensaios de compactação são apresentados na Tabela 10.

Tabela 10: Resultado dos ensaios de compactação dos materiais.

\begin{tabular}{ccccc}
\hline \multirow{2}{*}{ Material } & \multicolumn{2}{c}{ Intermediária } & \multicolumn{2}{c}{ Modificada } \\
& $\boldsymbol{\rho} \mathbf{d}$ máx $\left(\mathbf{g} / \mathbf{c m}^{\mathbf{3}}\right)$ & $\mathbf{W}_{\text {ótima }} \mathbf{( \% )}$ & $\mathbf{\rho d m a ́ x}\left(\mathbf{g} / \mathbf{c m}^{\mathbf{3}}\right)$ & $\mathbf{W}_{\text {ótima }} \mathbf{( \% )}$ \\
\hline ARM & 1,782 & 12,6 & 1,866 & 11,8 \\
$15 \%$ solo- ARM & 1,860 & 12,2 & 1,890 & 11,4 \\
$45 \%$ solo- ARM & 1,904 & 11 & 1,960 & 10 \\
Solo-AN & - & - & 2,350 & 6,5 \\
\hline
\end{tabular}

Observa-se que o aumento da energia de compactação da mistura ARM levou a um aumento na $\rho d_{\text {máx }}$ de $0,084 \mathrm{~g} / \mathrm{cm}^{3}(5 \%)$, para a mistura $15 \%$ solo-ARM o aumento foi de $0,03 \mathrm{~g} / \mathrm{cm}^{3}(2 \%)$, e de $0,056 \mathrm{~g} / \mathrm{cm}^{3}(3 \%)$ para a mistura $45 \%$ solo-ARM. A redução da umidade ótima foi em torno de $1 \%$ para as 3 misturas.

A adição de $15 \%$ de solo, elevou a massa específica da mistura de ARM em 0,078 g/cm³ (4\%), na energia intermediária e de $0,024(1 \%) \mathrm{g} / \mathrm{cm}^{3}$ na energia modificada. Já a adição de $45 \%$ de solo, provocou um aumento de $0,122 \mathrm{~g} / \mathrm{cm}^{3}(7 \%)$ na energia intermediária, e de 0,094 (5\%) na energia modificada.

Quanto à umidade ótima, com a adição de $15 \%$ de solo, houve a redução de $0,4 \%$, para ambas as energias de compactação. Para a mistura 45\% solo-ARM, a redução foi de 1,2\% na energia intermediária é 1,4\% na energia modificada. Essa redução na umidade ótima, ocorre devido à 
menor absorção de água do solo. Assim, quanto maior a porcentagem de solo na mistura, menor é a umidade ótima.

A mistura de solo-AN apresentou $\rho d \max$ de $0,460 \mathrm{~g} / \mathrm{cm}^{3}$ maior que a mistura $15 \%$ solo-ARM e $0,390 \mathrm{~g} / \mathrm{cm}^{3}$ maior que a mistura $45 \%$ solo-ARM e umidade ótima menor do que as misturas de solo-ARM para a energia modificada. A umidade ótima foi $4,9 \%$ menor que a mistura $15 \%$ solo-ARM e 3,5\% menor que a de 45\% solo-ARM. A $\rho d$ max maior e a umidade ótima menor da mistura solo-AN em relação as misturas de solo-ARM, ocorre devido à maior densidade e menor absorção do AN. Nas Figuras 17 e 18 estão ilustrados o comportamento dos materiais pesquisados.

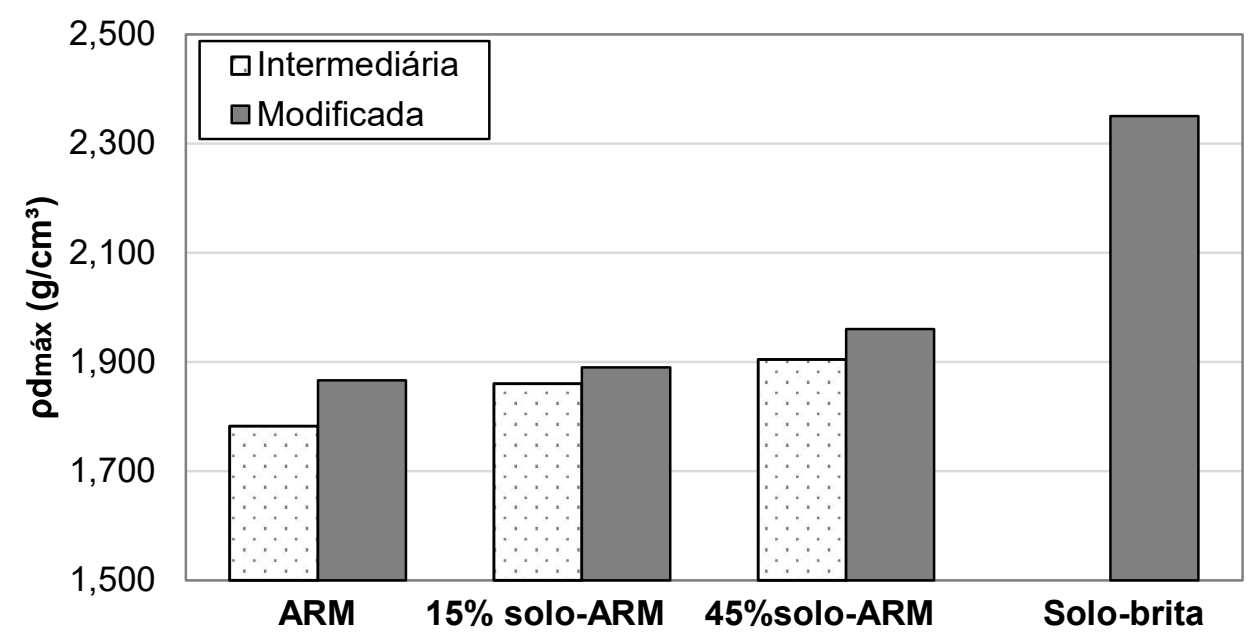

Figura 17: Massa específica aparente seca máxima dos materiais.

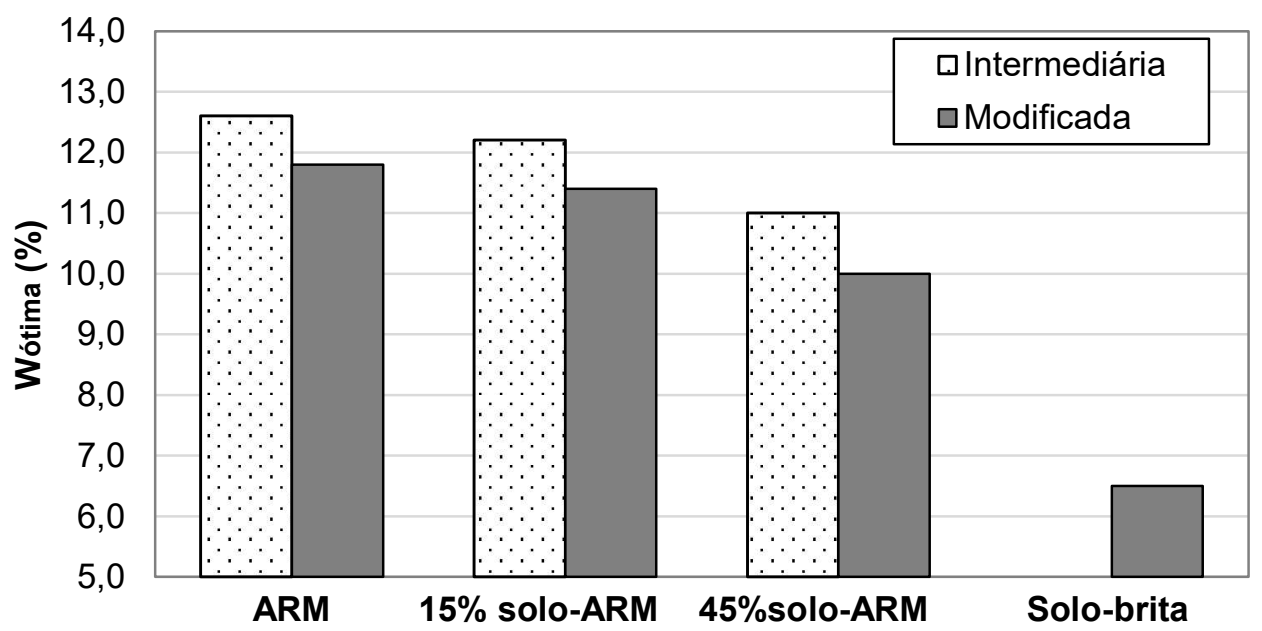

Figura 18: Umidade ótima dos materiais. 
Assim, fica evidente o aumento do $\rho$ dmáx e diminuição da Wótima com o aumento da energia de compactação para todos as misturas com ARM. Além disso, percebe-se que a adição de solo leva a um aumento do $\rho d_{\text {máx }}$ e diminuição da $W_{\text {ótima, }}$ devido o preenchimento dos vazios da mistura e menor absorção de água do solo.

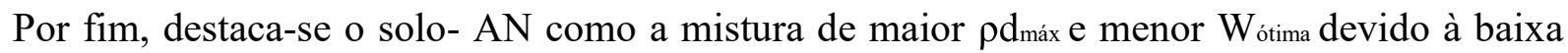
absorção e alta densidade do agregado natural.

\subsection{ENSAIOS DE DEGRADAÇÃO}

\subsubsection{Degradação do ARM}

Além do ensaio de Índice de Degradação Proctor, foi feita a análise da distribuição granulométrica após a compactação por impacto (Proctor) e estática, nas energias intermediária e modificada. As amostras foram produzidas na condição de umidade ótima e massa específica seca máxima. A análise consistiu da comparação das curvas granulométricas após a compactação com a curva granulométrica antes da compactação. Os resultados das porcentagens passantes antes e após a compactação em ambas as energias e formas de compactação são apresentadas na Tabela 11.

Tabela 11: Degradação do agregado reciclado.

\begin{tabular}{cccccc}
\hline \multirow{2}{*}{$\begin{array}{c}\text { Abertura } \\
\text { das peneiras } \\
(\mathbf{m m})\end{array}$} & $\begin{array}{c}\text { Antes da } \\
\text { compactação }\end{array}$ & \multicolumn{2}{l}{ Energia intermediária } & Energia Modificada \\
\cline { 3 - 6 }$(\%)$ & $\begin{array}{c}\text { Comp. } \\
\text { Impacto }\end{array}$ & $\begin{array}{c}\text { Comp. } \\
\text { Estática }\end{array}$ & $\begin{array}{c}\text { Comp. } \\
\text { Impacto }\end{array}$ & $\begin{array}{c}\text { Comp. } \\
\text { Estática }\end{array}$ \\
\hline 19 & 100 & 100 & 100 & 100 & 100 \\
9,52 & 78 & 81 & 79 & 82 & 83 \\
4,76 & 44 & 54 & 51 & 58 & 58 \\
2,00 & 36 & 42 & 39 & 47 & 46 \\
0,42 & 28 & 33 & 31 & 37 & 36 \\
0,074 & 9 & 10 & 9 & 11 & 11 \\
\hline
\end{tabular}

Os resultados indicam que ocorreu degradação do ARM para ambas as energias de compactação. Para a energia intermediária, na compactação estática, observa-se que a variação da porcentagem passante nas peneiras com abertura de $9,52 \mathrm{~mm}$ e de $0,074 \mathrm{~mm}$ foi praticamente nula. A maior variação da porcentagem passante ocorreu na peneira de 4,76 mm, onde houve um aumento de $7 \%$ da fração passante. 
A degradação produzida pela compactação dinâmica foi maior em todas as peneiras, chegando a $10 \%$ de aumento de porcentagem passante na peneira de $4,76 \mathrm{~mm}$.

A degradação para a energia modificada foi maior que para a energia intermediária em ambos os tipos de compactação, contudo não houve uma diferença significativa entre os métodos de compactação, como ocorreu na energia intermediária. A peneira que apresentou a maior degradação também foi a de abertura de $4,76 \mathrm{~mm}$, apresentando um aumento do percentual de material passante em 10\% na compactação estática e 11\% na compactação dinâmica. As Figuras 18 e 19 mostram os resultados obtidos.

As curvas apresentadas nas Figuras 19 e 20 mostram que as peneiras intermediárias de 4,76 mm e 2,00 $\mathrm{mm}$ foram as que tiveram a maior diferença no material passante antes e após a compactação para ambas as energias e métodos de compactação. No que se refere à energia de compactação, a degradação do material quando compactado na energia modificada foi maior do que o compactado na intermediária, tanto na compactação estática quanto na dinâmica. Isso mostra a importância da elevada energia de compactação durante a execução, promovendo a maior quebra dos grãos, minimizando assim a degradação por quebra dos grãos durante a vida útil do pavimento.

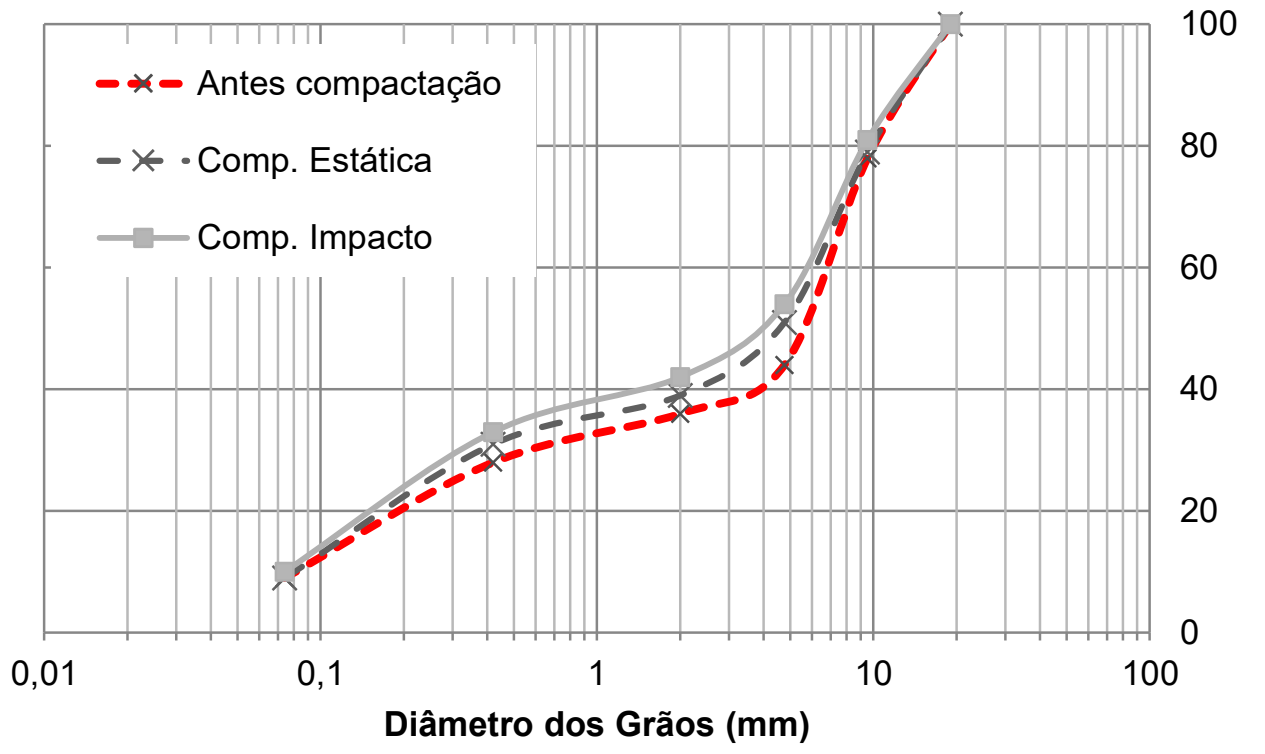

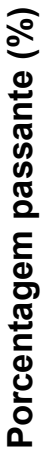

Figura 19: Degradação do ARM na energia intermediária. 


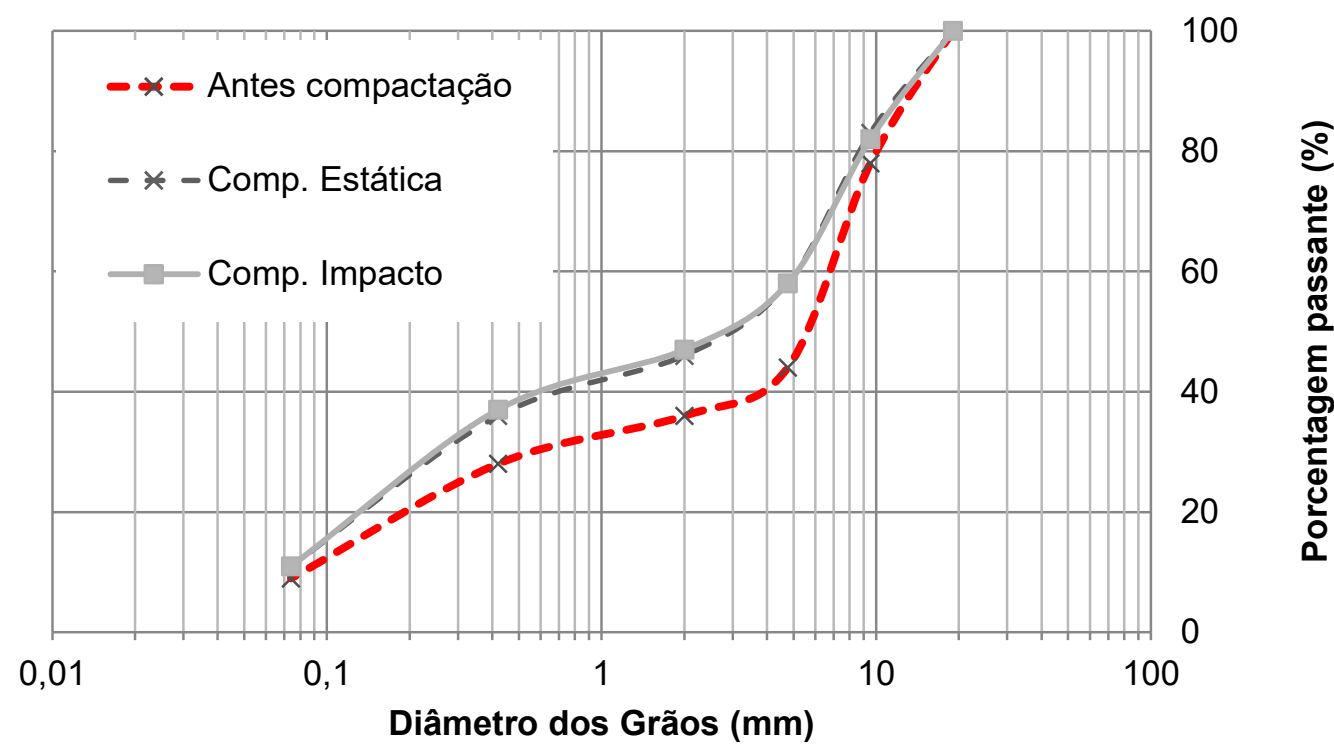

Figura 20: Degradação do ARM na energia modificada.

No que se refere ao tipo de compactação, observa-se que, na energia modificada, a degradação não sofreu muita influência do tipo de compactação, já na energia intermediária, o agregado sofreu maior degradação quando compactado de forma dinâmica do que quando compactado de forma estática.

Isso reforça a ideia de que a compactação na energia modificada promove a maior quebra dos grãos, desse modo, o tipo de compactação teve influência menor na degradação para o nível de energia.

É importante mencionar que a quebra melhora a acomodação das partículas, mas também aumenta o aparecimento de materiais cimentantes não hidratados e consequentemente potencializam as propriedades de auto-cimentação do ARM.

\subsubsection{Degradação do solo-ARM}

Os CPs para os ensaios de degradação das misturas solo-ARM foram moldados estaticamente na energia modificada, pois foi o método usado para moldagem dos CPs dos ensaios mecânicos das misturas solo-agregado. Os resultados de degradação da mistura 15\% solo-ARM são apresentados na Tabela 12. Pode-se observar que, assim como para o ARM, para as peneiras nas extremidades, a quantidade de material passante quase não sofreu alteração. Já as peneiras intermediárias, de 4,76 e 2,00 mm, tiveram a maior diferença de material passante, sendo de $14 \%$ e $12 \%$ respectivamente. 
Tabela 12: Degradação da mistura 15\% solo-ARM.

\begin{tabular}{|c|c|c|}
\hline \multirow{2}{*}{$\begin{array}{c}\text { Abertura das } \\
\text { peneiras }(\mathrm{mm})\end{array}$} & \multirow{2}{*}{$\begin{array}{c}\text { Antes da } \\
\text { compactação }\end{array}$} & \multirow{2}{*}{$\begin{array}{c}\text { Energia Modificada } \\
\text { Compactação estática }\end{array}$} \\
\hline & & \\
\hline 19 & 100,0 & 100 \\
\hline 9,52 & 81,0 & 88,0 \\
\hline 4,76 & 52,0 & 65,0 \\
\hline 2,00 & 46,0 & 54,0 \\
\hline 0,42 & 36,0 & 43,0 \\
\hline 0,074 & 12,0 & 13,0 \\
\hline
\end{tabular}

Na Figura 21, estão ilustradas as curvas antes e após compactação do 15\% solo- ARM. Observase que a degradação da mistura 15\% solo- ARM é semelhante a degradação da mistura ARM, ou seja, a adição de solo não levou a uma diminuição da degradação, contrariando o que era esperado. Acredita-se que a presença de $15 \%$ de solo, ainda mantêm o contato grão a grão, ou essa ocorrência pode estar relacionada à heterogeneidade do ARM (antes da compactação) tanto em sua composição quanto na granulometria, obtidas na fase de caracterização física do material.

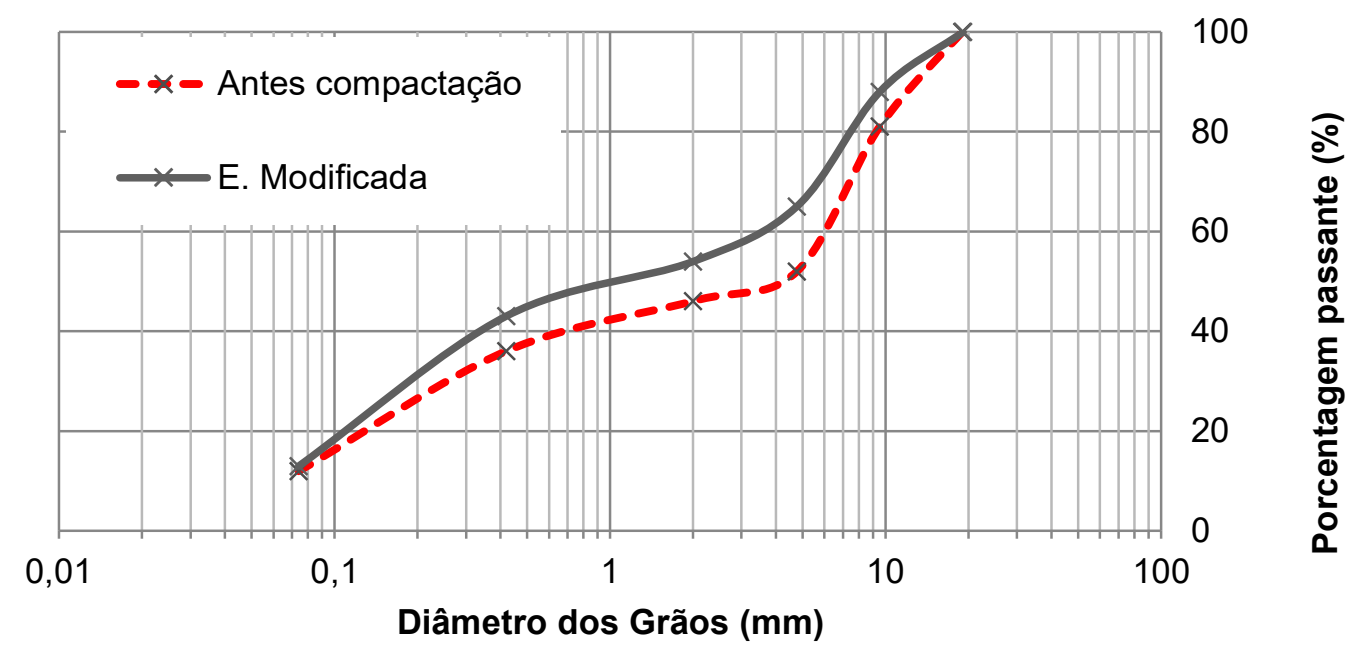

Figura 21: Degradação da mistura 15\% solo-ARM na energia modificada.

A degradação da mistura 45\% solo- ARM é apresentada na Tabela 13, onde se pode observar que a degradação da mistura segue a tendência de ser maior para as peneiras intermediárias. Esse fato pode estar relacionado com a composição do agregado, uma vez que a maior \% dos grãos estão contidos nas peneiras intermediárias, e com a maior quebra dos materiais cerâmicos. 
Tabela 13: Degradação da mistura 45\% solo-ARM.

\begin{tabular}{ccc}
\hline $\begin{array}{c}\text { Abertura das } \\
\text { peneiras (mm) }\end{array}$ & $\begin{array}{c}\text { Antes da } \\
\text { compactação }\end{array}$ & $\begin{array}{c}\text { Após a } \\
\text { compactação }\end{array}$ \\
\hline 19 & 100,0 & 100 \\
9,52 & 85,0 & 92,0 \\
4,76 & 55,0 & 70,0 \\
2,00 & 51,0 & 63,0 \\
0,42 & 42,0 & 49,0 \\
0,074 & 15,0 & 16,0 \\
\hline
\end{tabular}

Na Figura 22, estão apresentadas as curvas granulométricas antes e após a compactação da mistura 45\% solo-ARM. É possível observar o maior deslocamento da curva após a compactação para as peneiras intermediárias do que as extremidades, seguindo a tendência da degradação para o ARM e 15\% solo-ARM.

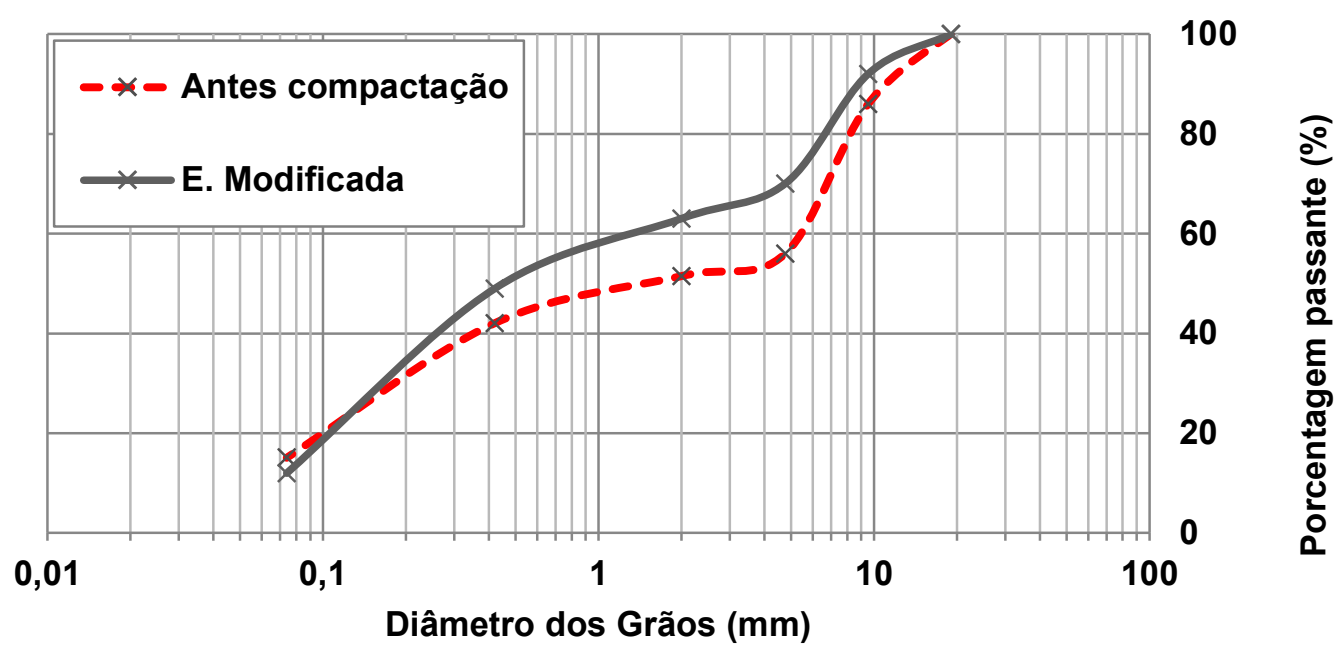

Figura 22: Degradação do ARM na energia modificada.

Observa-se, pelo deslocamento da curva após compactação, que houve uma degradação expressiva para a mistura 45\% solo-ARM, contrariando os resultados obtidos por Oliveira (2007), que obteve degradação menor para as misturas com adição de solo.

Observa-se também que para as três misturas com agregado reciclado, a curva segue o mesmo formato, sendo que para as peneiras onde as curvas antes da compactação apresentavam descontinuidade, a diferença do material passante antes e após a compactação foi maior, resultando em curvas mais continuas. Isso reforça o fato de que a degradação pode ser benéfica para as misturas com ARM, pois promovem um melhor entrosamento das partículas. 


\subsection{ENSAIOS DE CBR E EXPANSÃO}

Os ensaios de CBR e expansão foram realizados de acordo com a norma DNER 049/94. Na Tabela 14 estão apresentados os resultados dos ensaios de CBR dos materiais pesquisados.

Tabela 14: Resultados dos ensaios de CBR.

\begin{tabular}{ccc}
\hline Material & Energia & CBR (\%) \\
\hline \multirow{2}{*}{ ARM } & Intermediária & 80 \\
& Modificada & 150 \\
\multirow{2}{*}{ 15\% solo-ARM } & Intermediária & 75 \\
& Modificada & 110 \\
$45 \%$ solo-ARM & Intermediária & 50 \\
& Modificada & 80 \\
Solo- AN & Modificada & 110 \\
\hline
\end{tabular}

$\mathrm{Na}$ Figura 23, estão ilustrados os resultados obtidos. A linha tracejada delimita as recomendações de CBR mínimo para o uso de agregado reciclado em camada de base de pavimentos de baixo volume de tráfego, pela ABNT 15115/2004.

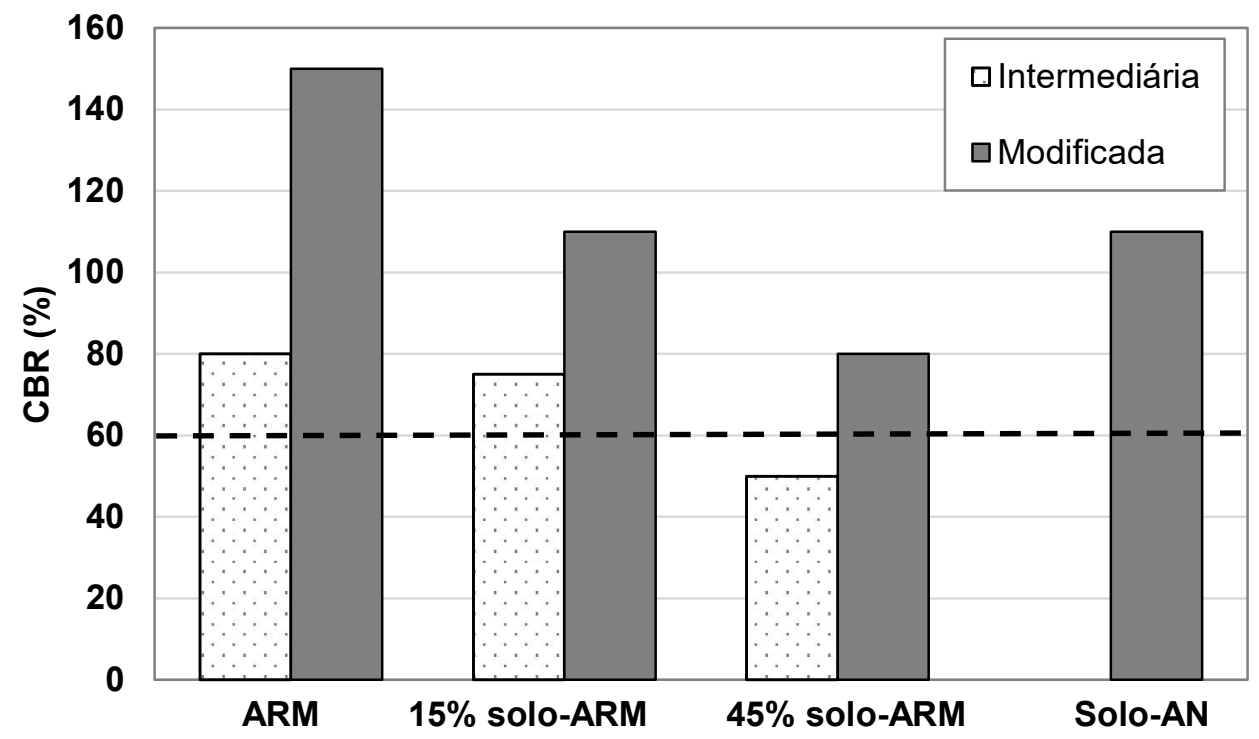

Figura 23: CBR das misturas estudadas.

De acordo com as recomendações da norma ABNT 15115/2004, todos os materiais podem ser usados como base de pavimentos de baixo volume de tráfego, com exceção da mistura $45 \%$ solo-ARM, quando compactada na energia intermediária, pois esta apresentou um CBR menor que $60 \%$. Quanto à expansão, todos os materiais pesquisados apresentaram valores menores 
que $0,5 \%$, que é o valor máximo recomendado pela norma ABNT 15115/2004 para uso de agregado reciclado em camadas de base de pavimentos.

Pode-se observar ainda, que o valor de CBR teve um aumento significativo com o incremento da energia de compactação, tanto para a mistura ARM quanto para as misturas de solo-ARM. Contudo a taxa de aumento foi mais expressiva para a mistura de ARM, que apresentou um valor de $80 \%$ para a energia intermediária, enquanto que, para a energia modificada, o valor foi de $150 \%$, ou seja um aumento de quase $90 \%$. Para a mistura de 15\% solo-ARM, na energia intermediária, o CBR foi de $75 \%$, enquanto que, para a energia modificada, esse valor foi de $110 \%$, apresentando um aumento de cerca de $50 \%$. Enquanto que para a mistura de $45 \%$ soloARM, o aumento do CBR foi de $60 \%$, variando de $50 \%$ na energia intermediária, para $80 \%$ na energia modificada.

Os resultados indicam ainda que a adição de solo, faz o CBR da mistura de ARM diminuir. Para a energia intermediária a adição de $15 \%$ provocou uma redução de $10 \%$ e para $45 \%$ de solo a redução foi de $40 \%$. Para a energia modificada a redução foi de $25 \%$ para a mistura $15 \%$ solo-ARM e quase $50 \%$ para a mistura 45\% solo-ARM, em relação a mistura de ARM, assim a adição de solo, provocou uma redução mais significativa para a energia modificada.

Os resultados de CBR da mistura solo-AN mostram que o valor de CBR foi $110 \%$ para a energia modificada, valor equivalente ao da mistura de $15 \%$ solo-ARM. Isso mostra que os valores de CBR para misturas com agregados reciclados, são satisfatórios quando comparados com misturas com agregado natural.

\subsection{ENSAIOS DE RESISTÊNCIA A COMPRESSÃO SIMPLES}

\subsubsection{Avaliação da RC imediata das misturas}

Os valores de RC sem cura do ARM, compactado nas energias intermediária e modificada, e das misturas de solo-ARM e solo-AN, compactados na energia modificada, são apresentados na Tabela 15. O desvio de ensaio foi baixo, em torno de 5\%, e não foram observados outliers. Todos os resultados dos ensaios de RCS estão apresentados no apêndice A. 
Tabela 15: RC imediata dos materiais.

\begin{tabular}{ccc}
\hline Materiais & $\begin{array}{c}\text { Energia de } \\
\text { compactação }\end{array}$ & $\begin{array}{c}\text { RCS } \\
\text { (kPa) }\end{array}$ \\
\hline ARM & Intermediária & 95 \\
& Modificada & 179 \\
$15 \%$ solo- ARM & Modificada & 225 \\
$45 \%$ solo- ARM & Modificada & 429 \\
Solo-AN & Modificada & 111 \\
\hline
\end{tabular}

A partir da Tabela 15, pode-se notar que o aumento da energia de compactação, provocou um aumento de $90 \%$ na resistência imediata do ARM. Pode-se perceber também que a adição de solo provocou um aumento significativo nos valores de RC, cerca de $25 \%$ para a mistura $15 \%$ solo-ARM e de 140\% para 45\% solo-ARM, devido ao comportamento coesivo do solo e melhor entrosamento das partículas. Na Figura 24, estão ilustrados os resultados obtidos.

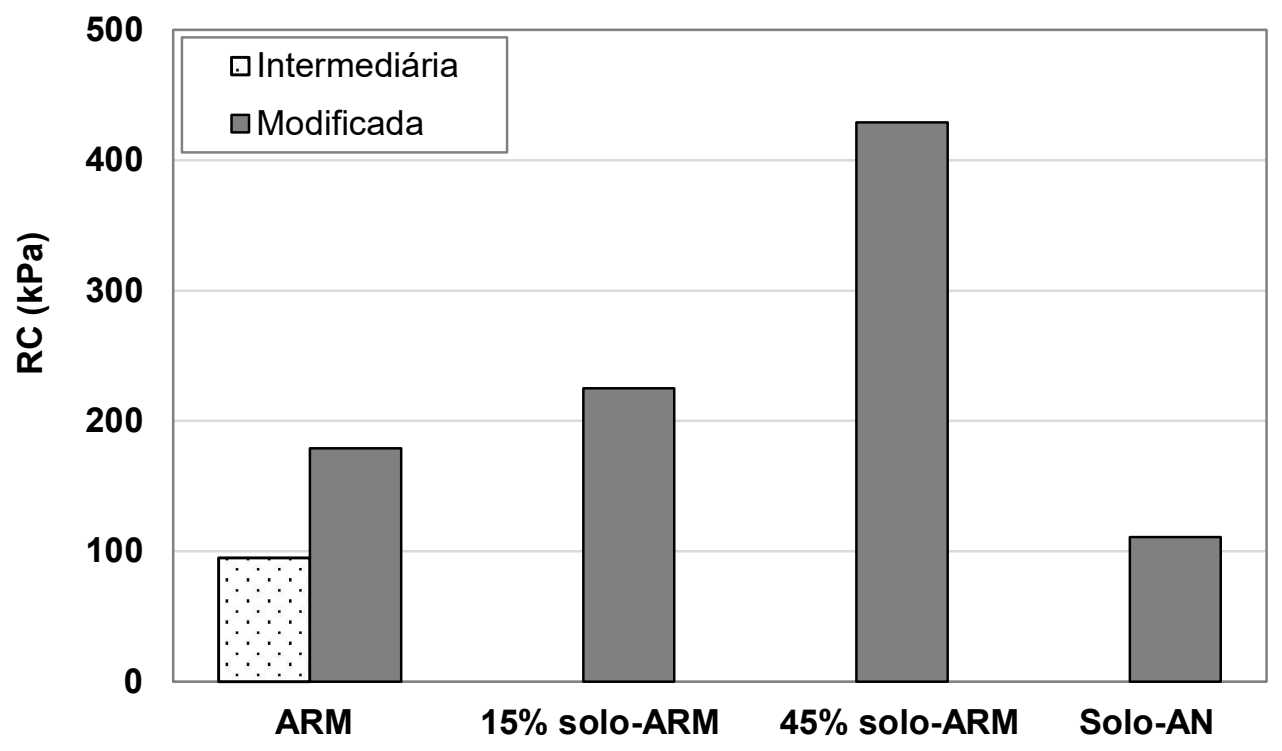

Figura 24: RC imediata dos materiais.

Analisando-se a Figura 24, é possível observar que ocorre o aumento de resistência do ARM com o aumento da energia de compactação e com a adição de solo. Além disso, o solo-AN apresentou o menor valor RC entre as misturas compactadas na energia modificada. Acreditase que o caráter não coesivo do $\mathrm{AN}$ e o fato do $\mathrm{AN}$ não degradar como o ARM, faz com que o entrosamento das partículas da mistura solo-AN seja menos eficiente que para as misturas soloARM. 


\subsubsection{Avaliação da $\mathrm{RC}$ ao longo do tempo}

Os resultados obtidos no ensaio de compressão simples ao longo do tempo para a mistura ARM são apresentados na Tabela 16 e na Figura 25. Devido à presença de um maior percentual de materiais cimentícios, os ensaios foram realizados até os 28 dias de cura. Foram observados 2 outliers no cálculo, 1 para o ARM aos 7 dias de cura e um para o ARM aos 28 dias de cura, na energia modificada.

Tabela 16: RC do ARM ao longo do tempo.

\begin{tabular}{ccc}
\hline $\begin{array}{c}\text { Tempo de cura } \\
\text { (dias) }\end{array}$ & $\begin{array}{c}\text { RC [kPa] } \\
\text { ARM-Intermediária }\end{array}$ & $\begin{array}{c}\text { RC [kPa] } \\
\text { ARM-Modificada }\end{array}$ \\
\hline 0 & 95 & 179 \\
7 & 129 & 229 \\
28 & 141 & 224 \\
\hline
\end{tabular}

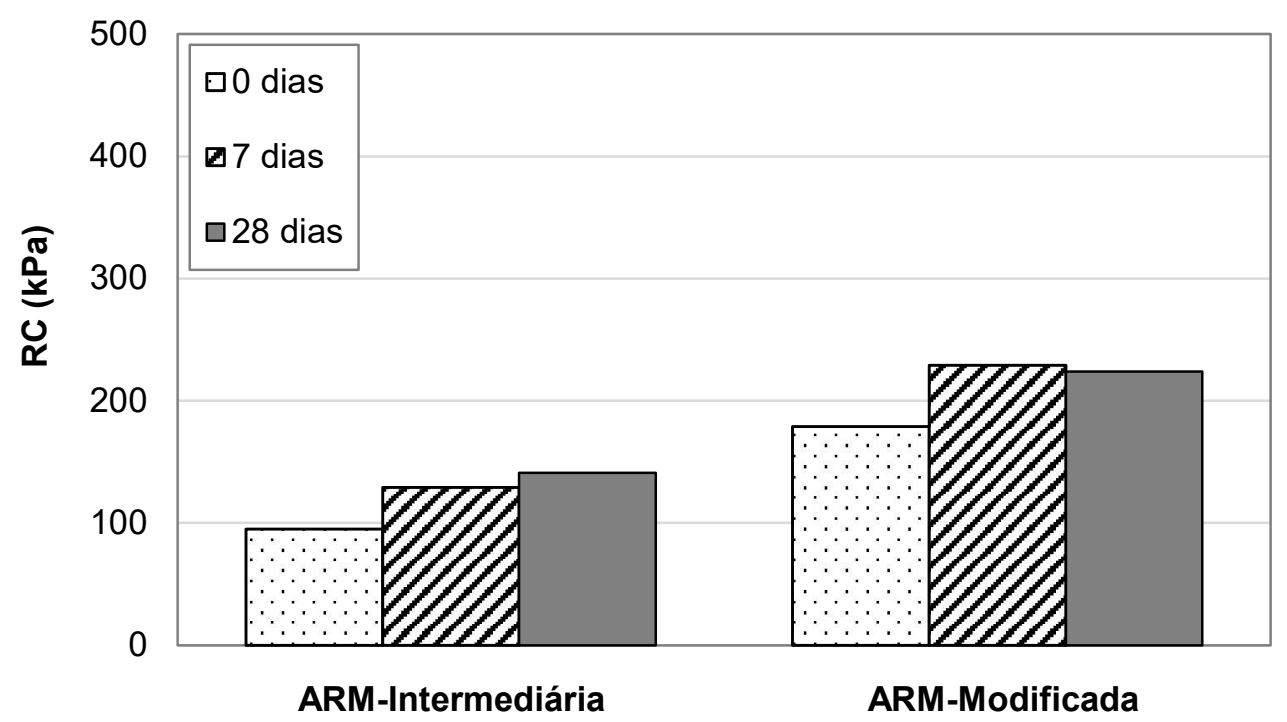

Figura 25: RC do ARM ao longo do tempo.

Analisando-se os resultados apresentados na Tabela 16 e ilustrados na Figura 25, observa-se que há uma tendência de aumento de resistência nos primeiros 7 dias de cura para ambas as energias de compactação. O aumento em termos percentuais foi de $36 \%$, na energia intermediária, e 28\% na energia modificada. Dos 7 aos 28 dias de cura, o ganho de resistência tende a se estabilizar, a pequena queda na energia modificada dos 7 para 28 dias, é atribuída a 
variabilidade do ensaio. Este aumento pode estar relacionado à cimentação devida à uma parte de cimento não hidratado exposta pela quebra de grãos de concreto durante a compactação do material, ou ainda pode estar relacionada à própria variabilidade do ensaio. Apesar do melhor entrosamento das partículas quando compactadas na energia modificada, o teor de umidade mais elevado da mistura na energia intermediária, pode ter contribuído para uma taxa de cimentação mais elevada.

Nas Tabela 17 e Figura 26, estão apresentados e ilustrados os resultados de RC das misturas com ARM aos 0 e 7 dias de cura. Lembrando que para as misturas solo-ARM, o tempo de cura até 7 dias foi considerado suficiente devido a menor parcela de materiais cimentícios que para a mistura ARM.

Tabela 17: RC dos materiais ao longo do tempo.

\begin{tabular}{ccccc}
\hline $\begin{array}{c}\text { Tempo de } \\
\text { cura (dias) }\end{array}$ & RCS [kPa] & ARM & $\begin{array}{c}\text { RCS [kPa] } \\
\mathbf{1 5 \%} \text { solo-ARM }\end{array}$ & $\begin{array}{c}\text { RCS [kPa] } \\
\mathbf{4 5 \%} \text { solo-ARM }\end{array}$ \\
\hline 0 & 179 & 225 & 429 \\
7 & 229 & 275 & 430 \\
\hline
\end{tabular}

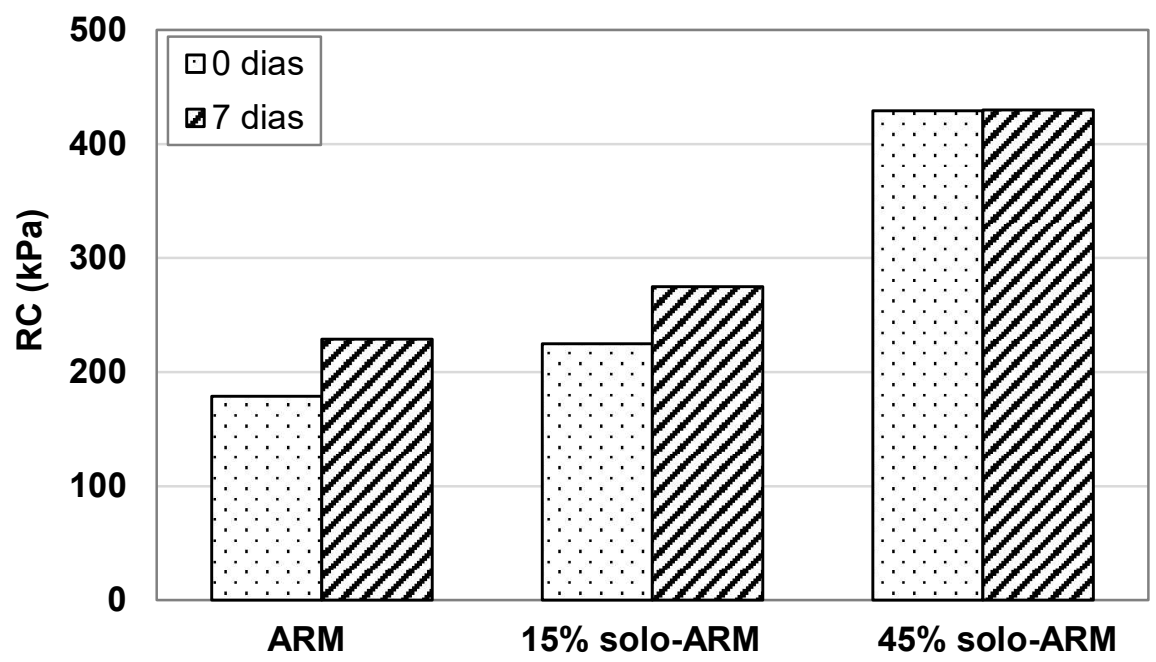

Figura 26: RC dos materiais ao longo do tempo.

Os resultados obtidos no ensaio de compressão simples para a mistura 15\% solo-ARM mostram que ocorre uma tendência de aumento de resistência nos primeiros 7 dias. Em termos percentuais, o aumento foi de $22 \%$, sendo este ganho menor que o do ARM compactado na energia modificada que foi de $28 \%$, esse resultado vai ao encontro dos apresentados por Grubba 
(2009), que obteve um ganho menor de resistência ao longo do tempo de cura para a mistura de ARC com adição de solo.

Apesar do aumento de resistência para o ARM e a mistura $15 \%$ solo-ARM, devido a cimentação, esses materiais apresentam um valor de $\mathrm{RC}$ baixos, fazendo que o material tenha um comportamento granular e não de camadas cimentadas.

Para a mistura 45\% solo-ARM, observa-se que o valor de RC não teve um acréscimo significativo aos 7 dias de cura. Este fato pode estar relacionado à baixa porcentagem de material cimentícios na mistura, além da ausência da fração fina do ARM, considerada mais reativa, além disso a alta porcentagem de solo (45\%), pode interferir nas reações químicas do material.

\subsection{ENSAIOS DE RESISTÊNCIA A TRAÇÃO POR COMPRESSÃO DIAMETRAL}

\subsubsection{Avaliação da RT imediata dos materiais}

Os valores de RT sem cura das misturas ARM, solo-ARM e solo-AN são apresentados na Tabela 18 e ilustrados na Figura 27. O desvio do ensaio foi baixo e não foram observados outliers. Todos os resultados dos ensaios de RTCD estão apresentados no apêndice B.

Tabela 18: RT imediata dos materiais.

\begin{tabular}{ccc}
\hline Materiais & $\begin{array}{c}\text { Energia de } \\
\text { compactação }\end{array}$ & $\begin{array}{c}\text { RT } \\
\text { (kPa) }\end{array}$ \\
\hline ARM & Intermediária & 2 \\
& Modificada & 10 \\
$15 \%$ solo-ARM & Modificada & 16 \\
$45 \%$ solo-ARM & Modificada & 30 \\
Solo-brita & Modificada & 11 \\
\hline
\end{tabular}




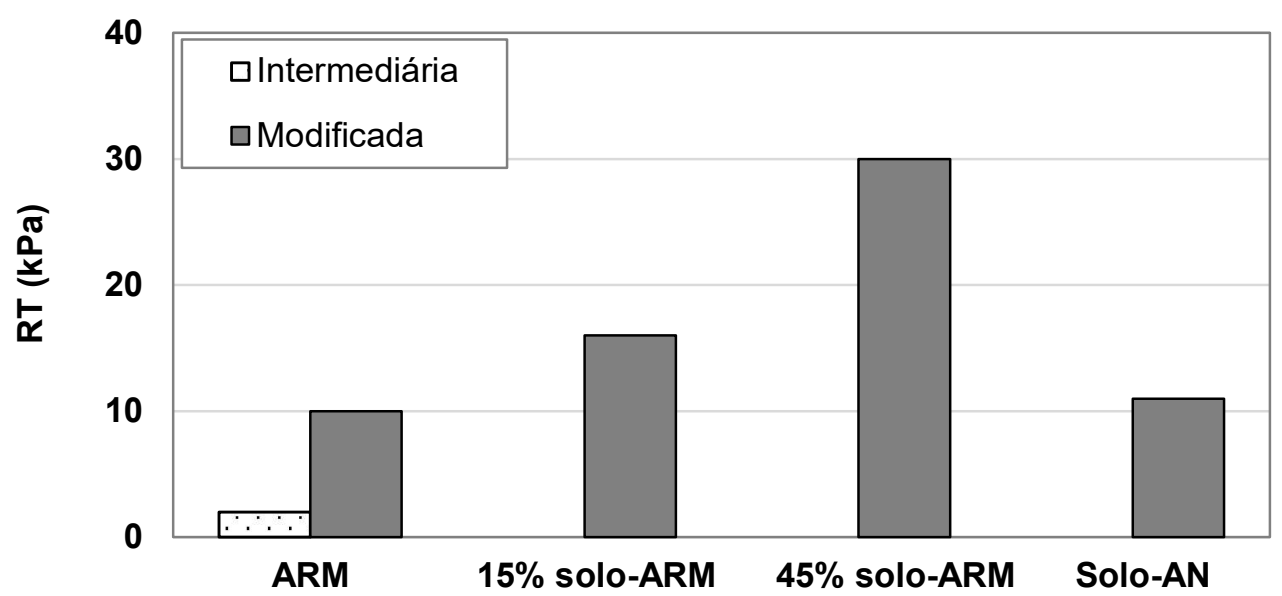

Figura 27: RT imediata dos materiais.

A partir da Tabela 18 e da Figura 27, pode-se observar que o aumento da energia de compactação, provocou um aumento significativo na resistência imediata do ARM.

Pode-se perceber também que a adição de solo provocou um aumento significativo nos valores de RT, o que está de acordo com o observado por Grubba (2009) para o ARC. A adição de 15\% de solo ao ARM aumentou RT em torno de $50 \%$, e a adição de $45 \%$ solo aumentou a RT em $300 \%$, quando comparada com os valores de RT da mistura com ARM.

O solo-AN apresentou valores equivalentes ao ARM, compactado na energia modificada, lembrando que os dois materiais se enquadram na faixa $C$, e possuem distribuições granulométricas parecidas. Estes resultados levam a inferir que a fração fina do ARM é capaz de promover entrosamento das partículas dos corpos de prova compostos exclusivamente de ARM, além disso, a degradação do ARM contribui para uma boa acomodação das partículas.

Já a mistura de $45 \%$ de solo-ARM apresentou um valor de RT cerca de $100 \%$ maior que a mistura de $15 \%$ solo-ARM, que contém $28 \%$ de areia e $15 \%$ de solo na sua composição, isso mostra que a natureza da fração fina proporciona um efeito significativo na coesão da mistura.

\subsubsection{Avaliação da RT ao longo do tempo}

Os resultados dos ensaios de resistência à tração por compressão diametral do ARM são apresentados na Tabela 19 e na Figura 28. O desvio do ensaio foi baixo, havendo a ocorrência de apenas um outlier para $1 \mathrm{CP}$ compactado na energia intermediária aos 7 dias de cura. 
Tabela 19: RT do ARM ao longo do tempo.

\begin{tabular}{ccc}
\hline $\begin{array}{c}\text { Tempo de cura } \\
\text { (dias) }\end{array}$ & $\begin{array}{c}\text { RT [kPa] } \\
\text { ARM-Intermediária }\end{array}$ & $\begin{array}{c}\text { RT [kPa] } \\
\text { ARM-Modificada }\end{array}$ \\
\hline 0 & 2 & 10 \\
7 & 6 & 10 \\
28 & 7 & 12 \\
\hline
\end{tabular}

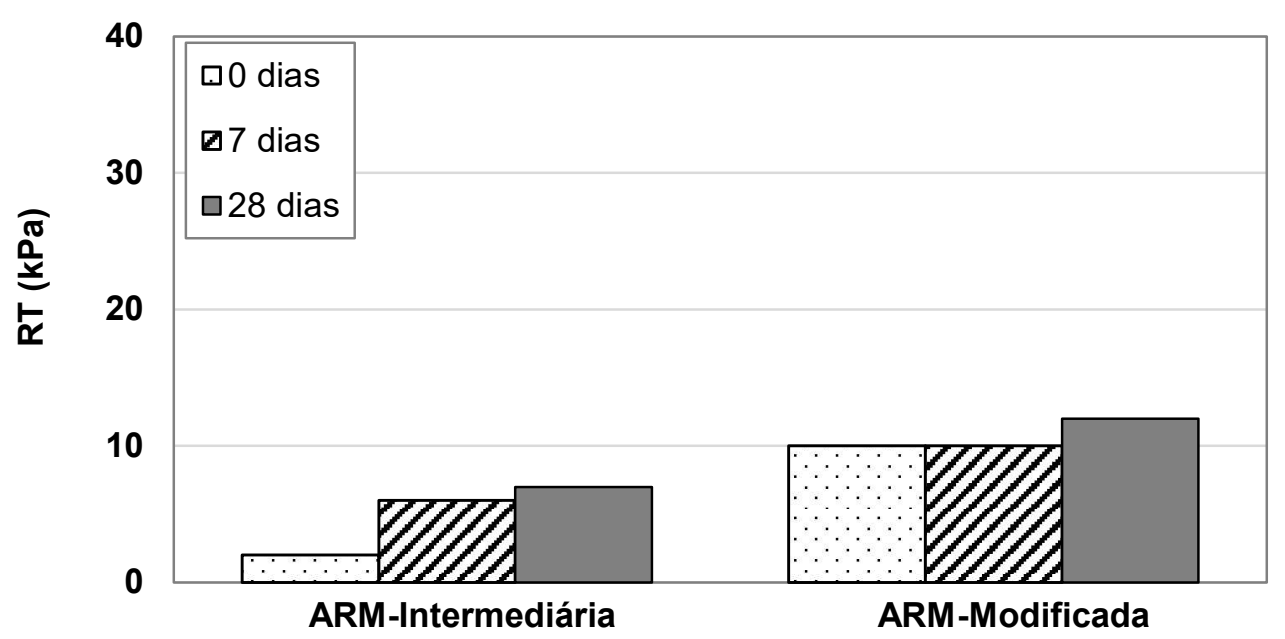

Figura 28: RT do ARM ao longo do tempo.

Analisando-se os resultados apresentados na Tabela 19 e ilustrados na Figura 28, observa-se a RT triplicou aos 7 dias de cura para a energia intermediária, após isso o ganho de RT tende à estabilização. Para a energia modificada, não foi possível observar um aumento significativo na propriedade ao longo do tempo de cura.

A RT para as misturas ARM e solo-ARM até os 7 dias de cura são apresentados na Tabela 20 e ilustrados na Figura 29. O desvio do ensaio foi pequeno, não sendo verificado outliers.

Tabela 20: RT dos materiais ao longo do tempo.

\begin{tabular}{cccc}
\hline $\begin{array}{c}\text { Tempo de } \\
\text { cura (dias) }\end{array}$ & $\begin{array}{c}\text { RT }[\mathrm{kPa}] \\
\text { ARM }\end{array}$ & $\begin{array}{c}\text { RT [kPa] } \\
\mathbf{1 5 \%} \text { solo-ARM }\end{array}$ & $\begin{array}{c}\text { RT [kPa] } \\
\mathbf{4 5 \%} \text { Solo-ARM }\end{array}$ \\
\hline 0 & 10 & 16 & 30 \\
7 & 10 & 19 & 31 \\
\hline
\end{tabular}




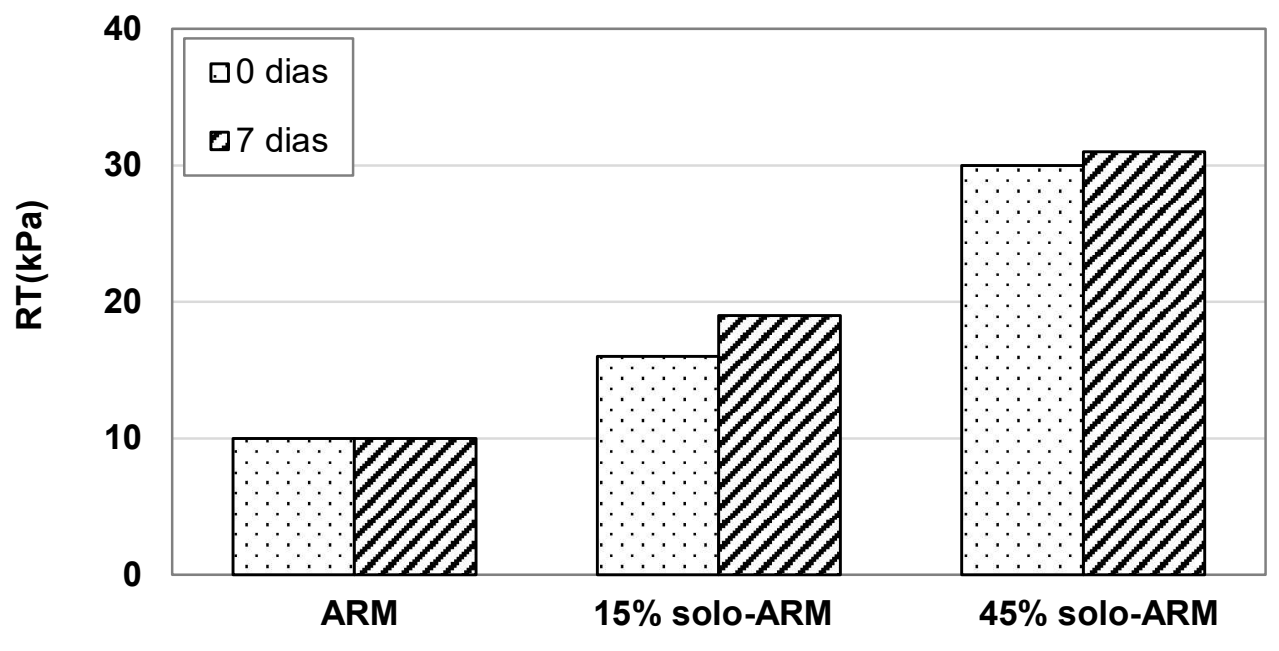

Figura 29: RT dos materiais ao longo do tempo.

Os resultados apresentados, indicam que, não houve ganho expressivo de resistência aos 7 dias de cura, para as misturas com ARM compactados energia modificada. Os baixos valores de resistência a tração podem ter mascarado um aumento de resistência com o tempo de cura, visto que o material apresentou ganho de resistência nas propriedades de RC.

\subsection{RESULTADOS DOS ENSAIOS TRIAXIAIS CÍCLICOS}

A partir dos ensaios triaxiais e por meio de regressões estatísticas, foram calibrados quatro modelos matemáticos para representar o módulo resiliente (MR) das misturas. No apêndice C encontram-se todos os modelos calibrados para obtenção do módulo de resiliência. Desses quatro modelos apresentados, foi selecionado o modelo composto, por ter sido o que apresentou maior coeficiente de correlação para todas as misturas e, por isso, deve melhor representar seus MR. Na Tabela 21 estão apresentados o modelo composto de cada mistura.

Observa-se que o $\mathrm{R}^{2}$ da maior parte das amostras situam-se acima de 0,8 , indicando que foram obtidos bons ajustes para os modelos. Além disso, quanto maior a adição de solo ao ARM, maior é o valor de k1, indicando que a adição de solo leva a maiores valores de módulo.

Os coeficientes $k 2$ e k3 possuem valores baixos, indicando que as tensões $\sigma_{3}$ e $\sigma_{d}$ tem influência menos significativa que a imposta pelo coeficiente K1 no valor de MR. Todos os materiais, com exceção do $15 \%$ solo-ARM (0 dias), apresentam k2 positivos, indicando que o incremento de $\sigma_{3}$ leva a um aumento do MR, o que é característico dos materiais granulares. Já o k3, 
apresenta valor negativo para todas as misturas, ou seja, o aumento da $\sigma_{\mathrm{d}}$ leva a um decréscimo no módulo de resiliência.

Tabela 21: Coeficientes do modelo composto.

\begin{tabular}{cccccc}
\hline Mistura & $\begin{array}{c}\text { Dias de } \\
\text { cura }\end{array}$ & k1 & $\mathbf{k 2}$ & $\mathbf{k 3}$ & $\mathbf{R}^{\mathbf{2}}$ \\
\hline \multirow{3}{*}{ ARM-Intermediária } & 0 & 17 & 0,725 & $-0,172$ & 0,86 \\
& 7 & 21 & 0,666 & $-0,115$ & 0,97 \\
& 28 & 175 & 0,176 & $-0,097$ & 0,78 \\
\hline \multirow{2}{*}{ ARM-Modificada } & 0 & 431 & 0,416 & $-0,578$ & 0,98 \\
& 7 & 1014 & 0,507 & $-0,828$ & 0,95 \\
& 28 & 387 & 0,524 & $-0,629$ & 0,80 \\
\hline \multirow{2}{*}{$15 \%$ solo- ARM } & 0 & 1161 & $-0,255$ & $-0,065$ & 0,86 \\
& 7 & 2641 & 0,391 & $-0,879$ & 0,73 \\
\hline \multirow{2}{*}{$45 \%$ solo- ARM } & 0 & 6433 & 0,232 & $-0,858$ & 0,88 \\
& 7 & 1344 & 0,713 & $-0,974$ & 0,92 \\
\hline Solo-brita & 0 & 54 & 0,621 & $-0,236$ & 0,88 \\
\hline
\end{tabular}

Para as misturas ARM em ambas as energias, observa-se que o incremento na tensão confinante eleva os valores de MR ( $\mathrm{k} 2$ positivo), que é um comportamento típico de um material granular, assim, maiores tensões confinantes e menores tensões desvio levam aos maiores módulos de resiliência. A tensão de desvio exerce pouca influência no MR da mistura ARM na energia intermediária, no entanto, na energia modificada a influência da tensão desvio é mais importante, isso pode acontecer devido a maior degradação do ARM quando compactado na energia modificada, promovendo maior entrosamento entre as partículas.

A adição de solo modificou o comportamento do material, de tal forma que a tensão confinante passa a exercer menor influência nos valores de MR. Destaca-se, por exemplo, a mistura $45 \%$ solo-ARM, onde a tensão de desvio foi mais significativa que a tensão confinante. Esse comportamento pode ser atribuído à mudança de granulometria (mais fina) e à coesão que o solo fornece a mistura.

A mistura de referência, solo-AN, apresentou comportamento típico de materiais granulares, ou seja, com predomínio do efeito da tensão confinante e a tensão de desvio exercendo pequena ou nenhuma influência nos valores de MR. Para melhor visualização do comportamento dos materiais, a Figura 30 apresenta os gráficos de superfície do modelo composto das misturas solo-AN e do ARM sem cura. 
Para ilustrar o efeito da cura nos valores de MR, a Figura 31 apresenta os gráficos do modelo composto das misturas ARM e 45\% solo-ARM, na energia modificada, com cura de 7 dias.

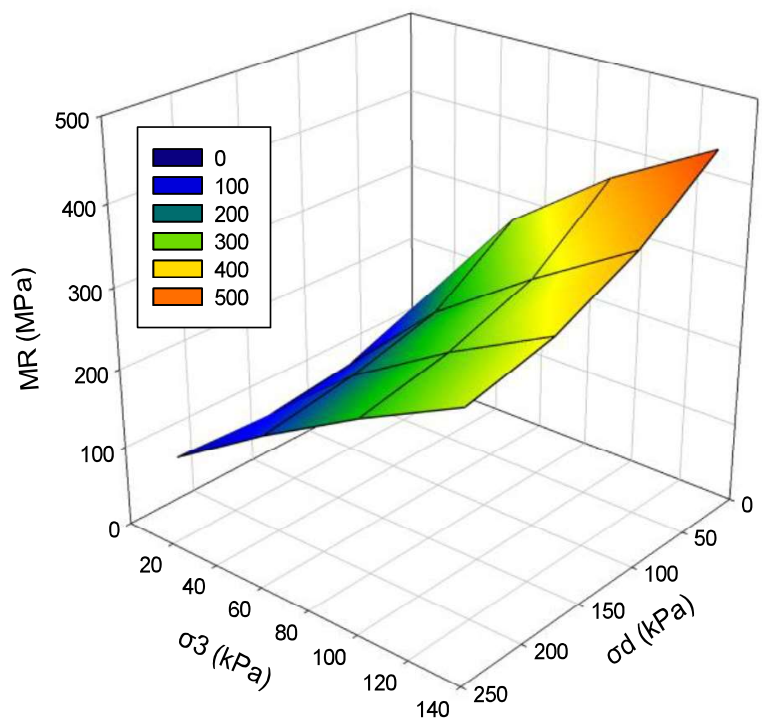

Solo-AN

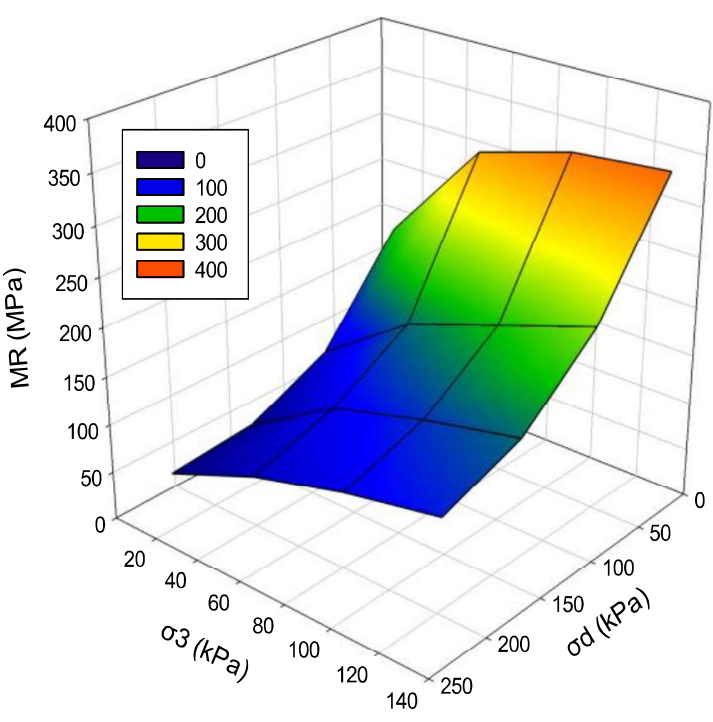

ARM-Modificada

Figura 30: Representação tridimensional do modelo composto para solo-AN e ARM.

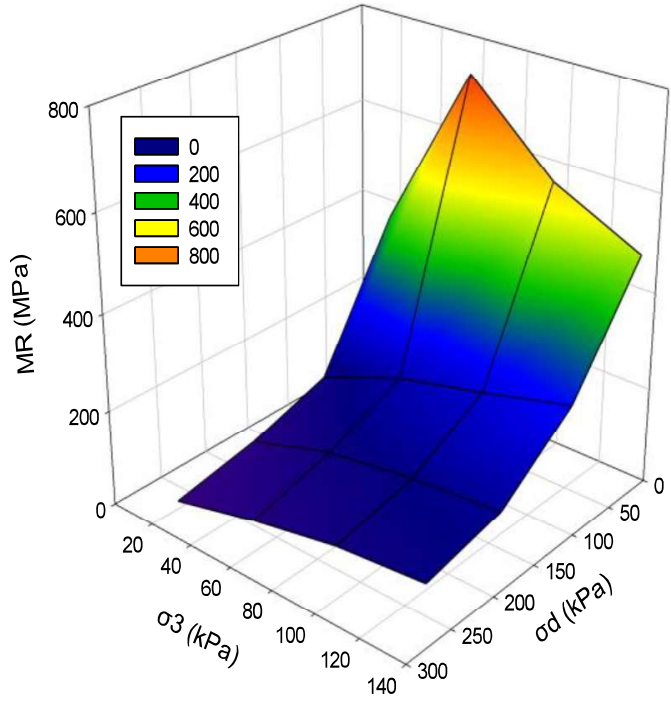

a) ARM -Modificada (7 dias)

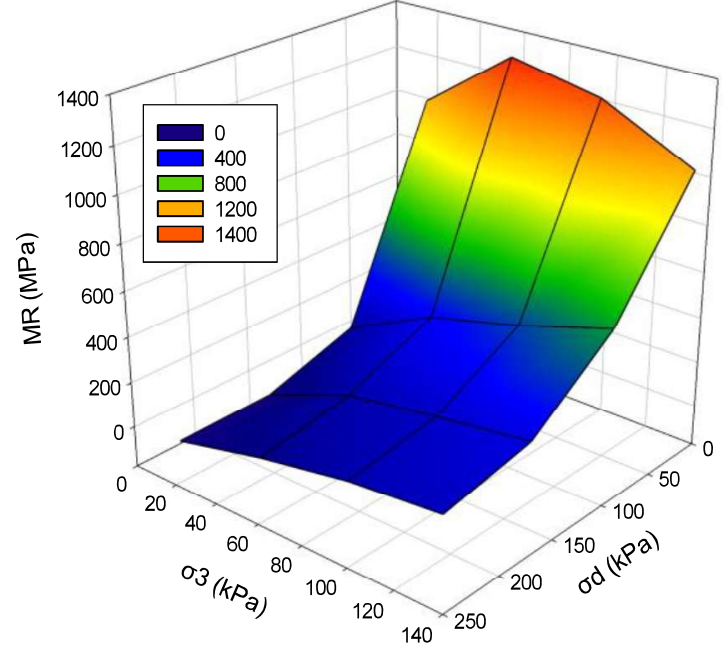

b) $45 \%$ solo-ARM -Modificada 7 dias)

Figura 31: Representação tridimensional do modelo composto para o MR do ARM e $45 \%$ solo- ARM aos 7 dias. 
Os gráficos da Figura 31 mostram um aumento da importância da tensão desvio na redução dos valores de $\mathrm{MR}$, esse comportamento pode estar relacionado a alguma do cimentação do material, contudo, a tensão confinante ainda exerce importante influência no aumento dos valores de MR, indicando que o material ainda tem comportamento granular. Para melhor entender o comportamento resiliente das misturas, é apresentado, a seguir, uma análise dos valores de MR resultantes do cálculo das tensões atuantes num pavimento hipotético (BVT).

\subsubsection{Avaliação do MR imediato dos materiais para pavimento BVT}

No processo iterativo de cálculo do MR por tensões no pavimento de baixo volume de tráfego, inicialmente adotou-se um valor de MR arbitrário para a camada de base. As tensões atuantes no centro dessa camada foram calculadas pelo programa MePADS. Em seguida, usando o modelo composto, calculou-se o novo valor de MR a ser inserido no programa com esse par de tensões. Esse procedimento foi repetido até que os valores de MR apresentassem diferenças menores que $1 \%$.

Os valores de MR sem cura do ARM, compactado nas energias intermediária e modificada, e das misturas de solo-ARM e solo-AN, compactados na energia modificada, calculados a partir do pavimento hipotético proposto, são apresentados na Tabela 22 e ilustrados na Figura 32.

Tabela 22: MR imediato dos materiais.

\begin{tabular}{lcc}
\hline \multicolumn{1}{c}{ Misturas } & $\begin{array}{c}\text { Energia de } \\
\text { compactação }\end{array}$ & $\begin{array}{c}\text { MR } \\
\text { (MPa) }\end{array}$ \\
\hline \multirow{2}{*}{ ARM } & Intermediária & 205 \\
& Modificada & 236 \\
15\% solo-ARM & Modificada & 299 \\
$45 \%$ solo-ARM & Modificada & 462 \\
Solo-AN & Modificada & 285 \\
\hline
\end{tabular}




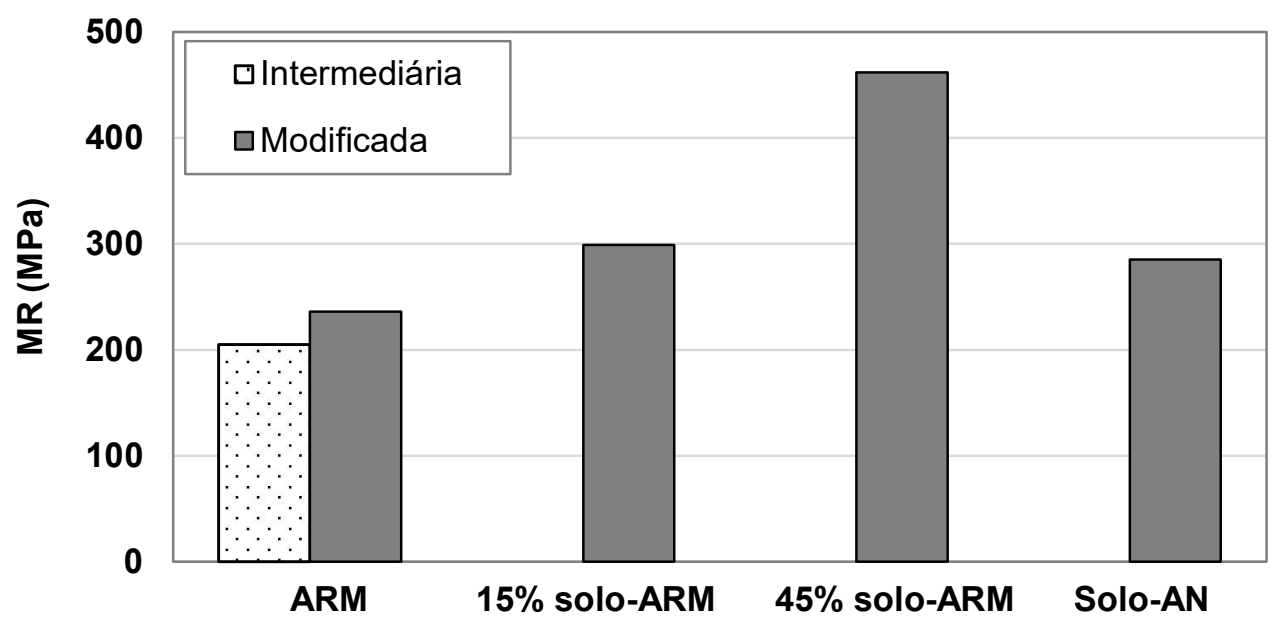

Figura 32: MR imediato dos materiais.

A partir da Tabela 22 e da Figura 32, pode-se observar que o aumento da energia de compactação, provocou um aumento de $15 \%$ no valor de MR do ARM, esse aumento foi pouco expressivo se comparados com os ganhos das demais propriedades mecânicas.

Pode-se perceber também que a adição de solo provocou um aumento significativo nos valores de MR. A adição de $15 \%$ de solo ao ARM levou a um aumento de MR, em torno de $30 \%$, e a mistura com 45\% solo praticamente dobrou o valor de MR, em relação à mistura ARM.

A mistura de solo-AN apresentou um MR 20\% maior do que o da mistura ARM, um valor de MR semelhante ao da mistura 15\% solo-ARM e $60 \%$ menor que o $45 \%$ solo-ARM. Esse comportamento é atribuído à adição de solo que tende a elevar o MR de materiais granulares.

\subsubsection{Avaliação do MR ao longo do tempo para pavimento BVT}

Os resultados de MR ao longo do tempo para as misturas ARM e solo-ARM são apresentados na Tabela 23 e ilustrados na Figura 33. Observa-se que para o ARM houve um aumento em torno de $15 \%$ para a energia intermediária e $20 \%$ para a energia modificada no MR nos 7 primeiros dias de cura, após isso a mistura tende a estabilização.

Tabela 23: MR do ARM ao longo do tempo.

\begin{tabular}{ccc}
\hline $\begin{array}{c}\text { Tempo de cura } \\
\text { (dias) }\end{array}$ & $\begin{array}{c}\text { MR [MPa] } \\
\text { ARM-Intermediária }\end{array}$ & $\begin{array}{c}\text { MR[MPa] } \\
\text { ARM-Modificada }\end{array}$ \\
\hline 0 & 205 & 236 \\
7 & 234 & 281 \\
28 & 250 & 268 \\
\hline
\end{tabular}




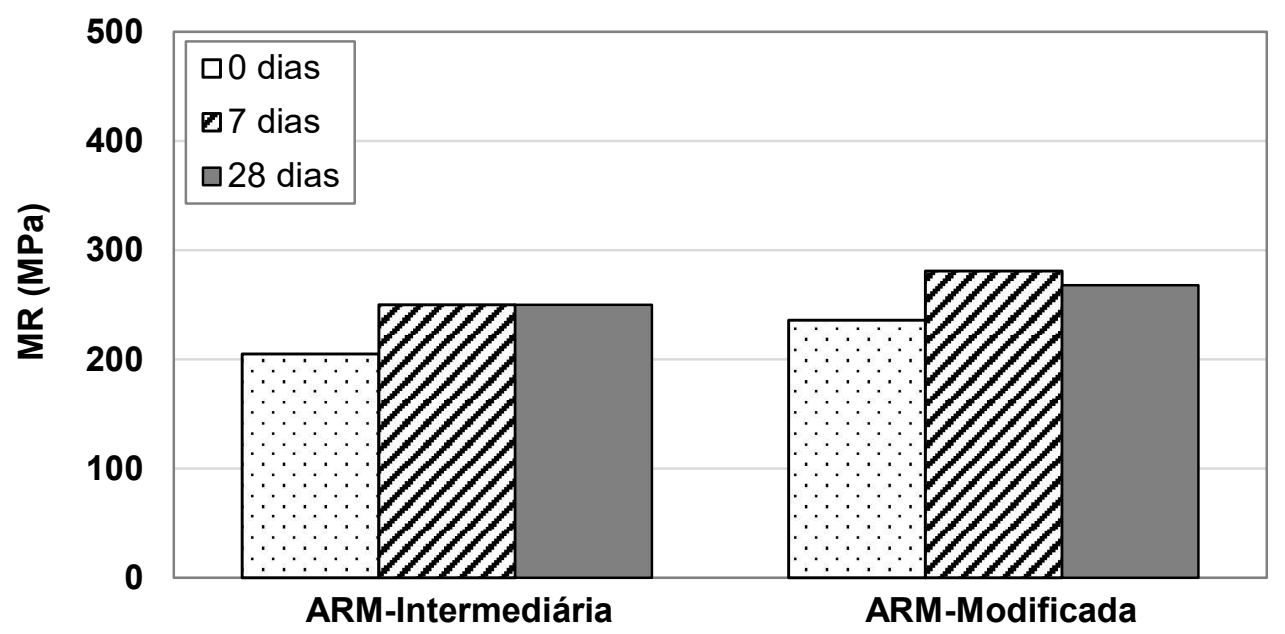

Figura 33: MR do ARM ao longo do tempo.

Para as misturas de ARM e solo-ARM, aos 7 dias de cura, os valores de MR encontram-se na Tabela 24 e na Figura 34.

Tabela 24: MR dos materiais ao longo do tempo.

\begin{tabular}{cccc}
\hline $\begin{array}{c}\text { Tempo de cura } \\
\text { (dias) }\end{array}$ & $\begin{array}{c}\text { MR[MPa] } \\
\text { ARM }\end{array}$ & $\begin{array}{c}\text { MR [MPa] } \\
\text { 15\%solo-ARM }\end{array}$ & $\begin{array}{c}\text { MR[MPa] } \\
\text { 45\% solo-ARM }\end{array}$ \\
\hline 0 & 236 & 299 & 462 \\
7 & 281 & 347 & 430 \\
\hline
\end{tabular}

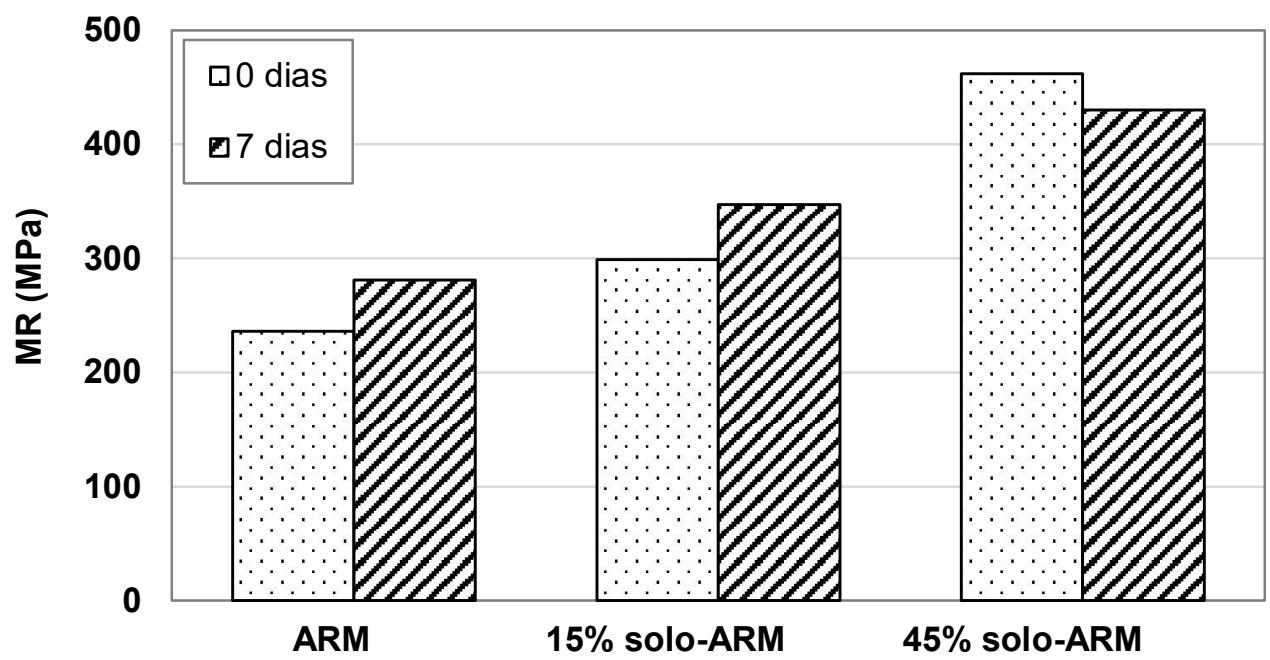

Figura 34: MR dos materiais ao longo do tempo.

Para a mistura $15 \%$ solo-ARM, verificou-se um aumento de cerca de $15 \%$, e para a mistura $45 \%$ solo-ARM, não houve aumento dessa propriedade aos 7 dias de cura, sendo o valor de MR 
da mistura $45 \%$ solo- ARM aos 7 dias de cura menor em 7\% que a resistência imediata atribuído a variabilidade do ensaio. Apesar do ganho de rigidez do ARM e da mistura 15\% solo-ARM, aos 7 dias, a mistura 45\% solo-ARM apresenta o maior valor de MR, o que significa que a adição de solo é benéfica no que se refere ao comportamento resiliente do material. 


\section{CONCLUSÕES}

\subsection{CONSIDERAÇÕES FINAIS}

O objetivo geral desta pesquisa foi estudar as propriedades físicas e o comportamento mecânico do agregado reciclado misto (ARM), produzido na cidade de São Carlos, e de misturas soloARM, e avaliar a possibilidade de sua utilização como material em camadas de pavimentos. A título de comparação foram analisados também uma mistura de solo-AN.

No que se refere à caracterização física, o ARM apresenta, em comparação com o agregado natural, maior absorção de água, menor densidade aparente e maior abrasão Los Angeles. Isso ocorre devido à baixa densidade dos materiais constituintes do ARM, principalmente da parcela de materiais cerâmicos.

Quanto à forma dos grãos e teor de materiais indesejáveis o ARM, os valores obtidos são menores do que os máximos exigidos pela norma.

Em relação aos ensaios de compactação, o ARM apresenta menor massa específica seca máxima e maior umidade ótima que as misturas de solo-ARM e solo-AN. Esse comportamento se explica pela maior absorção de água e menor densidade aparente do ARM, em relação ao agregado natural.

Considerando-se a energia de compactação, para o ARM, com aumento da energia de compactação, ocorreu um aumento da massa específica seca máxima e uma diminuição da umidade ótima, como esperado. Quando se compara o ARM e as misturas de solo-ARM, observou-se que a mistura 15\% solo-ARM apresenta massa específica maior e umidade ótima menor que o ARM. Para a mistura 45\% solo-ARM, essas mudanças na massa específica e na umidade ótima são ainda maiores.

No que se refere a degradação do ARM, observou-se quebra dos grãos significativa, principalmente, quando compactados na energia modificada. Em relação aos métodos de compactação, a compactação dinâmica promoveu uma maior quebra dos grãos que a compactação estática, quando compactados na energia intermediária. Quando compactados na energia modificada, o tipo de compactação não resultou em uma diferença significativa na degradação do material. 
No que se refere a energia de compactação, o emprego da energia modificada elevou todas as propriedades mecânicas do ARM. Recomenda-se para as misturas ARM e solo- ARM o emprego da energia modificada, pois além de elevar os parâmetros de projeto, possibilitando o uso do material para pavimentos com tráfego mais pesado, essa energia de compactação promove maior degradação do material, o que pode reduzir problemas de deformação permanente ao longo da vida útil do pavimento.

Em relação à resistência imediata dos materiais, compactados na energia modificada, observase que a adição de solo ao ARM, levou a uma diminuição nos valores de CBR, contudo provocaram um aumento na RC, RT e MR. É provável que a granulometria mais fina e a coesão do solo tenham contribuído para um melhor entrosamento de partículas e uma melhor trabalhabilidade das misturas solo-ARM.

A mistura solo-AN apresentou um CBR inferior ao da mistura ARM e equivalente ao das misturas solo-ARM, e apresentou o pior desempenho entre as misturas estudadas no que se refere à $\mathrm{RC}, \mathrm{RT}$ e MR.

Quanto à cimentação do ARM ao longo do tempo, observa-se que houve algum aumento das propriedades mecânicas nos 7 primeiros dias de cura, e após isso, o ganho de propriedade tende a estabilizar. Para as misturas de 45\% solo-ARM, não se constatou ganho de resistência, porque a substituição da fração fina do ARM (por solo) retirou uma parcela importante de materiais cimentantes.

Cabe salientar que a utilização de ARM e das misturas de solo-ARM ainda se mostraram uma alternativa ao emprego de agregados naturais na construção de camadas de base e sub-base de pavimentos. De acordo com a NBR 15115/2004, todas as misturas estudadas podem ser utilizadas como base de pavimentos de baixo volume de tráfego. As misturas ARM e 15\% soloARM possuem o CBR maior que $60 \%$, na energia intermediária. Para a mistura $45 \%$ soloARM, é indicada a utilização da energia modificada para atingir um valor de CBR maior que $60 \%$. Todos as misturas apresentaram expansão menor que $0,5 \%$.

Os resultados dessa pesquisa indicam que o ARM pode ser um material promissor mesmo em camadas de pavimentos de classes de tráfego mais pesadas, porque os parâmetros de projeto superam os valores mínimos recomendados pelas normas brasileiras para camadas de pavimentos de alto volume de tráfego. Quando dosado em misturas do tipo solo-agregado apresentam vantagens relacionadas à facilidade de produção e à melhora da trabalhabilidade. 


\subsection{SUGESTÕES PARA PESQUISAS FUTURAS}

- Estudar outras faixas de misturas solo-ARM (80/20 ou 70/30), usualmente utilizadas em solo-agregado.

- Avaliar a deformação permanente de misturas com ARM e solo-ARM.

- Construir e monitorar trechos experimentais com o ARM e misturas solo-ARM.

- Avaliar economicamente o ARM na construção de camadas de pavimentos 


\section{REFERÊNCIAS BIBLIOGRÁFICAS}

AGRELA, F.; BARBUDO, A.; RAMÍREZ, A.; AYUSO, J.; CARVAJAL, M. D.; JIMÉNEZ, J. R. Construction of road sections using mixed recycled aggregates treated with cement in Malaga, Spain. Resources, Conservation and Recycling, vol. 58, 98- 106p, 2012.

AMERICAN ASSOCIATION OF STATE HIGHWAY AND TRANSPORTATION OFFICIALS. AASHTO T 307-99: Standard Method of Test for Determining the Resilient Modulus of Soils and Aggregate Materials. Washington, 1999.

ARULRAJAH, A.; PIRATHEEPA, J.; BO, M. W.; SIVAKUGAN, N. Geotechnical characteristics of recycled crushed brick blends for pavement sub-base applications. Canadian Geotechnical Journal, v. 49, n. 7, p. 796-811, jul. 2012.

ARULRAJAH, A.; DISFANI, M. M.; HORPIBULSUK, S.; SUKSIRIPATTANAPONG, C.; PRONGMANEE, N. Physical properties and shear strength responses of recycled construction and demolition materials in unbound pavement base/subbase applications. Construction and Building Materials, v. 58, p. 245-257, maio 2014.

ASSOCIAÇÃO BRASILEIRA DE EMPRESAS DE LIMPEZA PÚBLICA E RESÍDUOS ESPECIAIS (ABRELPE). Panorama dos resíduos sólidos no Brasil. São Paulo, 2016.

ASSOCIAÇÃO BRASILEIRA DE NORMAS TÉCNICAS. NBR 7181: Solo - Análise granulométrica. Rio de Janeiro, 1984.

.NBR 7182: Solo- Ensaio de compactação. Rio de Janeiro, 1984.

.NBR 10004: Resíduos sólidos- Classificação. Rio de Janeiro, 2004.

.NBR 15115: Agregados reciclados de resíduos de construção civil- Execução de camadas de pavimentação- Procedimentos- Rio de Janeiro, 2004.

BAPTISTA JUNIOR, J. V.; ROMANEL, C. Sustentabilidade na indústria da construção: uma logística para reciclagem dos resíduos de pequenas obras. Revista Brasileira de Gestão Urbana, v. 5, n. 480, p. 27, 2013.

BARBUDO A.; AGRELA, F.; AYUSO J.; JIMÉNEZ J. R.; POON C. S. Statistical analysis of recycled aggregates derived from different sources for sub-base applications. Construction and Building Materials, , v. 28, n. 1, p. 129-138, mar. 2012.

BEHERA, M., BHATTACHARYYA, S.K.; MINOCHA, A.K., DEOLYIA, R.; MAITI, S. Recycled aggregate from C\&D waste \& its use in concrete - A breakthrough towards in construction sector: A review. Construction and Building Materials, v.68, p. 502-516, 2014.

BEJA, I. A. Agregado reciclado de construção e demolição com adição de aglomerantes hidráulicos como sub-base de pavimentos. 219 p. Dissertação (Mestrado) Escola Politécnica, Universidade de São Paulo, 2014.

BENNERT, T.; PAPP, W. J.; MAHER, A.; GUCUNSKI, N. Utilization of Construction and Demolition Debris Under Traffic-Type Loading in Base and Subbase Applications. 
Transportation Research Record: Journal of the Transportation Research Board, v. 1714, p. 33-39, jan. 2000.

BIO Intelligence Service. Service contract on management of construction and demolition waste - SR1. Final Report Task 2. European Commission DG ENV, 2011.

BRASIL. Conselho Nacional do Meio Ambiente. Resolução Conama n⿳0. 307, de 5 de julho de 2002. Estabelece diretrizes, critérios e procedimentos para a gestão dos resíduos da construção civil. Brasília, DF, 5 jul, 2002.

BRASIL. Conselho Nacional do Meio Ambiente. Altera a Resolução Conama no ${ }^{\circ}$. 307, de 5 de julho de 2002, incluindo o amianto na classe de resíduos perigosos. Resolução $\mathbf{n}^{\mathbf{0}}$. 348, de 16 de ago, 2004. Diário Oficial da União, no. 158, p.70, 17 de ago, 2004.

BRASIL. Conselho Nacional do Meio Ambiente. Altera o art. $3^{\circ}$. da resolução Conama $n^{\circ} .307$, de 5 de julho de 2002, estabelecendo nova classificação para o gesso. Resolução n ${ }^{\mathbf{0}}$. 431, de 24 de maio, 2011. Diário Oficial da União nº 99, p.123, 25 de maio, 2004.

BRASILEIRO, L. L.; MATOS, J. M. E. Revisão bibliográfica: reutilização de resíduos da construção e demolição na indústria da construção civil (Literature review: reuse of construction and demolition waste in the construction industry). Cerâmica, v. 61, p. 178-189, 2015.

CARDOSO, R.; SILVA, R.V., BRITO, J., DHIR, R. Use of recycled aggregates from construction and demolition waste in geotechnical applications: A literature review. Waste Management, v.9, p. 131-45, 2016.

CARNEIRO, A. P.; BURGOS, P. C.; \& ALBERTE, E. P. V. Uso do agregado reciclado em camadas de base e sub-base de pavimentos. Projeto Entulho Bom. Salvador: EDUFBA/Caixa Econômica Federal, p. 190-227, 2001.

CORDOBA, R. E. Estudo do gerenciamento integrado de resíduos de construção e demolição do município de São Carlos-SP. 406p. Dissertação (Mestrado). Escola de Engenharia de São Carlos, Universidade de São Paulo, 2010.

DE BRITO, J.; PEREIRA, A. S.; CORREIA, J. R. Mechanical behaviour of non-structural concrete made with recycled ceramic aggregates. Cement and Concrete Composites, v. 27, n. 4, p. 429-433, abr. 2005.

Departamento Nacional de Estradas de Rodagem. DNER 303/97. Pavimentação - Base estabilizada granulometricamente. Rio de Janeiro, 1997.

. DNER PRO 120/97. Coleta de amostra de agregados Rio de Janeiro, 1997.

DNER 093-94. Solos-Determinação da densidade real. Rio de Janeiro, 1994.

. DNER 122-94. Solos- determinação do limite de liquidez - método de referência e método expedito. Rio de Janeiro, 1994.

. DNER 082-94. Solos- determinação do limite de plasticidade. Rio de Janeiro, 1994. 
DNER 201-94. Solos-cimento- compressão axial de corpos-de-prova cilíndricos. Rio de Janeiro, 1994.

DNER 131/94. Solos- determinação do Módulo de resiliência. Rio de Janeiro, 1994.

DNER 049/94. Solos- determinação do Índice de Suporte Califórnia utilizando amostras não trabalhadas. Rio de Janeiro, 1994.

DNER-ME 138/94. Misturas Betuminosas- determinação da resistência a tração por compressão diametral. Mato Grosso, 1994.

DNER 081/98. Agregados- determinação da absorção e da densidade do agregado graúdo. Rio de Janeiro, 1998.

1998.

DNER 035/98. Agregados- determinação da abrasão "Los Angeles". Rio de Janeiro,

Departamento de Estradas de Rodagem do estado do Paraná, DER-PR-ET-DE-P00/007. Pavimentação - Camadas estabilizadas granulometricamente. Paraná, 2006.

DER-PR- ET-DE-P00/006. Sub-base ou base de solo-brita. Paraná, 2006.

DEPARTAMENTO DE ESTRADAS DE RODAGEM DE SÃO PAULO. DER IP-DE-

P00/001: Projeto de Pavimentação. São Paulo, 2006.

GRÉGOIRE, C., DETHY, B., THEYS, F., \& CORREIA, A. G. Assessment of the mechanical performance of recycled unbound materials for pavement subbase layers. Geotechnical Engineering for Infrastructure and development, p. 271-276, 23 nov. 2015.

GRUBBA, D.C.R.P. Estudo do comportamento mecânico de um agregado reciclado de concreto para utilização em construção rodoviária. 138p. Dissertação (Mestrado) Escola de Engenharia de São Carlos, Universidade de São Paulo, 2009.

JIMÉNEZ, J. R.; AGRELA, F.; AYUSO, J.; LÓPES, M. Estudio comparativo de los áridos reciclados de hormigón y mixtos como material para sub-bases de carreteras. Materiales de Construcción, v. 61, n. 302, p. 289-302, 30 jun. 2011.

LEITE, F.C. Comportamento mecânico de agregado reciclado de resíduo sólido da construção civil em camadas de base e sub-base de pavimentos. 185p. Dissertação (Mestrado) Escola Politécnica, Universidade de São Paulo, 2007.

LEITE, F. DA C.; MOTTA, R. DOS S.; VASCONCELOS, K. L.; BERNUCCI, L. Laboratory evaluation of recycled construction and demolition waste for pavements. Construction and Building Materials, v. 25, n. 6, p. 2972-2979, jun. 2011.

LIMA, J. A. R. Proposição de diretrizes para produção e normalização de resíduo de construção reciclado e de suas aplicações em argamassas e concretos. 1999. 222 p. Dissertação (Mestrado). Escola de Engenharia de São Carlos da Universidade de São Paulo, 1999. 
MARQUES NETO, J. C. Diagnóstico para estudo de Gestão de Resíduos de Construção e Demolição do Município São Carlos-SP. 155p. Dissertação (Mestrado). Escola de Engenharia de São Carlos, Universidade de São Paulo, 2003.

MELBOUCI, B. Compaction and shearing behaviour study of recycled aggregates. Construction and Building Materials, v. 23, n. 8, p. 2723-2730, ago. 2009.

MOLENAAR, A. A. A.; VAN NIEKERK A. A. Effects of gradation, composition, and degree of compaction on the mechanical characteristics of recycled unbound materials. Transportation Research Record: Journal of the Transportation Research Board, v. 1787, p. 73-82, jan. 2002.

MOTTA, R. DOS S. Estudo laboratorial de agregado reciclado de resíduo sólido da construção civil para aplicação em pavimentação de baixo volume de tráfego. $134 \mathrm{p}$. Dissertação (Mestrado) Escola Politécnica, Universidade de São Paulo, 2005.

MOTTA, L. M. G.; FERNANDES, C. Utilização de Resíduo Sólido da Construção Civil em Pavimentação Urbana. 12 ${ }^{\mathbf{a}}$ Reunião de Pavimentação Urbana, ABPv, Aracaju, Sergipe, 2003.

OIKONOMOU, N. D. Recycled concrete aggregates. Cement and Concrete Composites, v. 27, n. 2, p. 315-318, fev. 2005.

OLIVEIRA, J. C. D. Indicadores de potencialidades e desempenho de agregados reciclados de resíduos sólidos da construção civil em pavimentos flexíveis. 190p. Tese (doutorado). Universidade de Brasília, 2007.

PINTO, A. R. A. G. Fibras de curauá e sisal como reforço em matrizes de solo. 103p. Dissertação (mestrado)- Pontifícia Universidade Católica, Rio de Janeiro, 2008.

PONNADA, M. R.; KAMESWARI, P. Construction and demolition waste management-A review. International Journal of Advanced Science and Technology, vol. 80, 19-46p, 2015.

POON, C. S.; CHAN, D. Feasible use of recycled concrete aggregates and crushed clay brick as unbound road sub-base. Construction and Building Materials, v. 20, n. 8, p. 578-585, out. 2006.

POON, C.-S.; QIAO, X. C.; CHAN, D. The cause and influence of self-cementing properties of fine recycled concrete aggregates on the properties of unbound sub-base. Waste Management, v. 26, n. 10, p. 1166-1172, jan. 2006.

PORTO, M. E. H. C.; SILVA, S. V. Reaproveitamento dos entulhos de concreto na construção de casas populares. In: XVIII encontro nacional de engenharia de produção. Rio de Janeiro, 2008.

SÁEZ, P. V.; MERINO, M. R.; PORRAS-AMORES, C. Managing construction and demolition (C\&D) waste - a European perspective. International Conference on Petroleum and Sustainable Development, IPCBEE, v. 26, p.27-31, 2011.

SANTOS, A. G.; TEIXEIRA, R. W.; DE MELLO, E. A.; TEIXEIRA, J. Avaliação do custo de construção de uma estrutura de pavimento empregando agregado reciclado de RCD. REEC - Revista Eletrônica de Engenharia Civil, v. 10, n. 1, 7 jul. 2015. 
SOUSA, W.F. Estudo sobre a aplicação de agregado reciclado de concreto em construção de pavimentos. 122p. Dissertação (Mestrado) Escola de Engenharia de São Carlos, Universidade de São Paulo, 2011.

TAVIRA, J.; JIMÉNEZ, J. R.; AYUSO, J.; SIERRA, M. J.; \& LEDESMA, E. F. Functional and structural parameters of a paved road section constructed with mixed recycled aggregates from non-selected construction and demolition waste with excavation soil. Construction and Building Materials, v. 164, p. 57-69, mar. 2018.

TRICHÊS, G.; KRYCKYJ, P.R. Aproveitamento de entulho da construção civil na pavimentação urbana. In: Anais do IV Congresso Brasileiro de Geotecnia Ambiental, v.4, p. 259-265, São José dos Campos, 1999.

XUAN, D. X.; MOLENAAR, A. A. A.; HOUBEN, L. J. M. Evaluation of cement treatment of reclaimed construction and demolition waste as road bases. Journal of cleaner production, $v$. 100, p. 77-83, 2015.

ZORDAN, S. E. Metodologia de avaliação do potencial de reciclagem de resíduos. 2003. 464 p. Tese (Doutorado). Escola Politécnica da Universidade de São Paulo, São Paulo. 


\section{APÊNDICE A- RESISTÊNCIA À COMPRESSÃO}

Tabela 1: Teste de Grubbs- ARM intermediária

\begin{tabular}{cccccc}
\hline $\begin{array}{c}\text { Dias de } \\
\text { cura }\end{array}$ & RC [kPa] & RCmédio [kPa] & $\begin{array}{c}\text { Desvio } \\
\text { padrão }\end{array}$ & $\mathbf{G}$ & RC definitivo [kPa] \\
\hline \multirow{2}{*}{0} & 87 & 95 & 11 & 1,13 & 95 \\
& 107 & & 0,38 & 129 \\
\hline 7 & 91 & 129 & 13 & 0,76 & \\
\hline \multirow{2}{*}{28} & 130 & & 1,05 & 141 \\
& 115 & 146 & 18 & 1,10 & \\
\hline
\end{tabular}

Tabela 2: Teste de Grubbs- ARM modificada

\begin{tabular}{cccccc}
\hline $\begin{array}{c}\text { Dias de } \\
\text { cura }\end{array}$ & $\mathbf{R C}[\mathbf{k P a}]$ & $\mathbf{R C m e ́ d i o ~ [ k P a ]}$ & $\begin{array}{c}\text { Desvio } \\
\text { padrão }\end{array}$ & $\mathbf{G}$ & RC definitivo [kPa] \\
\hline \multirow{2}{*}{0} & 182 & & & 0,29 & \\
& 169 & 179 & 9 & 1,11 & 179 \\
& 187 & & & 0,83 & 229 \\
\hline \multirow{2}{*}{7} & 230 & & & 0,62 & \\
& 227 & 209 & 34 & 0,53 & 224 \\
& 170 & & & 1,15 & \\
\hline \multirow{2}{*}{28} & 222 & & & 0,63 & \\
& 226 & 246 & 38 & 0,52 & \\
& 290 & & & 1,15 & \\
\hline
\end{tabular}

Tabela 3: Teste de Grubbs- 15\% solo-ARM modificada

\begin{tabular}{cccccc}
\hline $\begin{array}{c}\text { Dias de } \\
\text { cura }\end{array}$ & RC [kPa] & RCmédio [kPa] & $\begin{array}{c}\text { Desvio } \\
\text { padrão }\end{array}$ & G & RC definitvo [kPa] \\
\hline \multirow{2}{*}{0} & 229 & & & 0,91 & \\
& 221 & 225 & 4 & 1,07 & 225 \\
& 226 & & & 0,16 & \\
\hline \multirow{2}{*}{7} & 275 & & & 0,00 & 275 \\
& 281 & 275 & 6 & 1,00 & \\
\hline
\end{tabular}


Tabela 4: Teste de Grubbs- $45 \%$ solo-ARM modificada

\begin{tabular}{cccccc}
\hline $\begin{array}{c}\text { Dias de } \\
\text { cura }\end{array}$ & RC [kPa] & RCSmédio [kPa] & $\begin{array}{c}\text { Desvio } \\
\text { padrão }\end{array}$ & G & RC definitivo [kPa] \\
\hline \multirow{2}{*}{0} & 406 & & & 1,11 & 429 \\
& 435 & 429 & 21 & 0,29 & \\
& 446 & & & 0,82 & 430 \\
7 & 438 & & & 0,22 & \\
\hline
\end{tabular}

Tabela 5: Teste de Grubbs- Solo-AN modificada

\begin{tabular}{cccccc}
\hline $\begin{array}{c}\text { Dias de } \\
\text { cura }\end{array}$ & RC [kPa] & RCmédio [kPa] & $\begin{array}{c}\text { Desvio } \\
\text { padrão }\end{array}$ & G & RC definitivo [kPa] \\
\hline \multirow{2}{*}{0} & 115 & & & 0,87 & 111 \\
& 106 & 111 & 5 & 1,09 & \\
\hline
\end{tabular}




\section{APÊNDICE B- RESISTÊNCIA À TRAÇÃO}

Tabela 1: Teste de Grubbs- ARM intermediária

\begin{tabular}{|c|c|c|c|c|c|}
\hline $\begin{array}{c}\text { Dias de } \\
\text { cura }\end{array}$ & $\mathrm{RT}[\mathrm{kPa}]$ & RTmédio [kPa] & $\begin{array}{l}\text { Desvio } \\
\text { padrão }\end{array}$ & $\mathbf{G}$ & RT definitvo [kPa] \\
\hline & 2,2 & & & 1,09 & \\
\hline \multirow[t]{3}{*}{0} & 1,8 & 2 & 0 & 0,22 & 2 \\
\hline & 1,6 & & & 0,87 & \\
\hline & 5,6 & & & 0,92 & \\
\hline \multirow[t]{3}{*}{7} & 6,3 & 6 & 1 & 0,15 & 6 \\
\hline & 7,4 & & & 1,07 & \\
\hline & 7,0 & & & 0,58 & \\
\hline \multirow[t]{2}{*}{28} & 7,0 & 7 & 1 & 0,58 & 7 \\
\hline & 8,0 & & & 1,15 & \\
\hline
\end{tabular}

Tabela 2: Teste de Grubbs- ARM modificada

\begin{tabular}{|c|c|c|c|c|c|}
\hline $\begin{array}{c}\text { Dias de } \\
\text { cura }\end{array}$ & $\mathrm{RT}[\mathrm{kPa}]$ & RTmédio [kPa] & $\begin{array}{l}\text { Desvio } \\
\text { padrão }\end{array}$ & G & RT definitivo $[\mathrm{kPa}]$ \\
\hline & 11 & & & 1,00 & \\
\hline \multirow[t]{3}{*}{0} & 9 & 10 & 1 & 1,00 & 10 \\
\hline & 10 & & & 0,00 & \\
\hline & 10 & & & 0,58 & \\
\hline \multirow[t]{3}{*}{7} & 6 & 9 & 2 & 1,15 & 10 \\
\hline & 10 & & & 0,58 & \\
\hline & 14 & & & 0,87 & \\
\hline \multirow[t]{2}{*}{28} & 11 & 13 & 2 & 1,09 & 13 \\
\hline & 13 & & & 0,22 & \\
\hline
\end{tabular}


Tabela 3: Teste de Grubbs- 15\% solo-ARM modificada

\begin{tabular}{|c|c|c|c|c|c|}
\hline Dias de cura & RT [kPa] & RTmédio [kPa] & Desvio padrão & G & RT definitivo $[\mathrm{kPa}]$ \\
\hline \multirow{3}{*}{0} & 18 & & & 0,80 & \\
\hline & 17 & 16 & 2 & 0,32 & 16 \\
\hline & 14 & & & 1,12 & \\
\hline \multirow{3}{*}{7} & 21 & & & 0,80 & \\
\hline & 20 & 19 & 2 & 0,32 & 19 \\
\hline & 17 & & & 1,12 & \\
\hline
\end{tabular}

Tabela 4: Teste de Grubbs- $\mathbf{4 5 \%}$ Solo- ARM modificada

\begin{tabular}{|c|c|c|c|c|c|}
\hline Dias de cura & $\mathrm{RT}[\mathrm{kPa}]$ & RTmédio [kPa] & Desvio padrão & $\mathbf{G}$ & RT definitivo [kPa] \\
\hline \multirow{3}{*}{0} & 26 & & & 0,91 & \\
\hline & 29 & 30 & 4 & 0,16 & 30 \\
\hline & 34 & & & 1,07 & \\
\hline \multirow{3}{*}{7} & 32 & & & 0,16 & \\
\hline & 35 & 31 & 4 & 0,91 & 31 \\
\hline & 27 & & & 1,07 & \\
\hline
\end{tabular}

Tabela 5: Teste de Grubbs- Solo-AN modificada

\begin{tabular}{cccccc}
\hline $\begin{array}{c}\text { Dias de } \\
\text { cura }\end{array}$ & RT [kPa] & RTmédio [kPa] & $\begin{array}{c}\text { Desvio } \\
\text { padrão }\end{array}$ & G & RT definitivo [kPa] \\
\hline \multirow{2}{*}{0} & 9 & & & 1,09 & 11 \\
& 11 & 11 & 2 & 0,22 & \\
\hline
\end{tabular}


APÊNDICE C- MODELOS (MÓDULO DE RESILIÊNCIA)

Tabela 1: Modelos módulo de resiliência do ARM

\begin{tabular}{|c|c|c|c|c|c|c|}
\hline Material & Dias de cura & Modelo & k1 & k2 & k3 & $\mathbf{R}^{2}$ \\
\hline \multirow{12}{*}{ ARM- INT } & \multirow{4}{*}{0} & $f(\sigma d)$ & 105,7741 & 0,122 & - & 0,02 \\
\hline & & $f(\sigma 3)$ & 9,951 & 0,6672 & - & 0,83 \\
\hline & & Composto & 17,2245 & 0,7275 & $-0,1723$ & 0,87 \\
\hline & & Universal & 869,1292 & 1,0514 & $-1,3481$ & 0,85 \\
\hline & \multirow{4}{*}{7} & $f(\sigma d)$ & 116,037 & 0,141 & - & 0,046 \\
\hline & & $f(\sigma 3)$ & 14,831 & 0,623 & - & 0,94 \\
\hline & & Composto & 20,692 & 0,666 & $-1,116$ & 0,97 \\
\hline & & Universal & 1198,418 & 0,897 & $-1,225$ & 0,95 \\
\hline & \multirow{4}{*}{28} & $f(\sigma d)$ & 241,178 & $-0,009$ & - & 0 \\
\hline & & $f(\sigma 3)$ & 147,826 & 0,113 & - & 0,47 \\
\hline & & Composto & 175,035 & 0,176 & $-0,097$ & 0,78 \\
\hline & & Universal & 2265,2761 & 0,257 & $-0,611$ & 0,79 \\
\hline \multirow{12}{*}{ ARM- MOD } & \multirow{4}{*}{0} & $f(\sigma d)$ & 2114,946 & $-0,554$ & - & 0,71 \\
\hline & & $f(\sigma 3)$ & 43,3753 & 0,367 & - & 0,21 \\
\hline & & Composto & 430,8864 & 0,416 & $-0,578$ & 0,98 \\
\hline & & Universal & 3110,995 & 0,795 & $-3,593$ & 0,9 \\
\hline & \multirow{4}{*}{7} & $f(\sigma d)$ & 2010,888 & $-0,529$ & - & 0,48 \\
\hline & & $f(\sigma 3)$ & 101,857 & 0,155 & - & 0,06 \\
\hline & & Composto & 1014,294 & 0,507 & $-0,828$ & 0,95 \\
\hline & & Universal & 3584,004 & 0,642 & $-3,323$ & 0,77 \\
\hline & \multirow{4}{*}{28} & $f(\sigma d)$ & 1717,8 & $-0,469$ & - & 0,37 \\
\hline & & $f(\sigma 3)$ & 52,4736 & 0,339 & - & 0,2 \\
\hline & & Composto & 386,863 & 0,524 & $-0,629$ & 0,8 \\
\hline & & Universal & 2500,009 & 0,752 & $-2,635$ & 0,64 \\
\hline
\end{tabular}


Tabela 2: Modelos módulo de resiliência das misturas solo-agregado

\begin{tabular}{|c|c|c|c|c|c|c|}
\hline Material & $\begin{array}{c}\text { Dias de } \\
\text { cura }\end{array}$ & Modelo & k1 & k2 & $\mathbf{k 3}$ & $\mathbf{R}^{2}$ \\
\hline \multirow{8}{*}{$\begin{array}{l}\text { 15\% solo- } \\
\text { ARM }\end{array}$} & \multirow{5}{*}{0} & $f(\sigma d)$ & 1385,76 & $-0,259$ & - & 0,51 \\
\hline & & $f(\sigma 3)$ & 1451,566 & $-0,292$ & - & 0,86 \\
\hline & & Composto & 1660,615 & $-0,255$ & $-0,065$ & 0,88 \\
\hline & & Universal & 5796,484 & $-0,376$ & 0,219 & 0,89 \\
\hline & & $f(\sigma d)$ & 3531,252 & $-0,596$ & - & 0,57 \\
\hline & \multirow{3}{*}{7} & $f(\sigma 3)$ & 493,044 & $-0,164$ & - & 0,05 \\
\hline & & Composto & 2641,148 & 0,391 & $-0,879$ & 0,73 \\
\hline & & Universal & 5272,196 & 0,203 & $-2,537$ & 0,43 \\
\hline \multirow{8}{*}{$\begin{array}{c}45 \% \text { solo- } \\
\text { ARM }\end{array}$} & \multirow{4}{*}{0} & $f(\sigma d)$ & 7194,14 & $-0,642$ & - & 0,81 \\
\hline & & $f(\sigma 3)$ & 1333,914 & $-0,325$ & - & 0,23 \\
\hline & & Composto & 6432,692 & 0,232 & $-0,858$ & 0,87 \\
\hline & & Universal & 8268,596 & $-0,0467$ & $-2,145$ & 0,58 \\
\hline & \multirow{4}{*}{7} & $f(\sigma d)$ & 2740,922 & $-0,464$ & - & 0,38 \\
\hline & & $f(\sigma 3)$ & 270,83 & 0,092 & - & 0,01 \\
\hline & & Composto & 1343,88 & 0,713 & $-0,934$ & 0,92 \\
\hline & & Universal & 8023,36 & 0,639 & $-4,176$ & 0,51 \\
\hline \multirow{4}{*}{ Solo-AN } & \multirow{4}{*}{0} & $f(\sigma d)$ & 264,846 & 0,007 & - & 0 \\
\hline & & $f(\sigma 3)$ & 24,164 & 0,549 & - & 0,78 \\
\hline & & Composto & 53,747 & 0,621 & $-0,236$ & 0,88 \\
\hline & & Universal & 1527,472 & 0,863 & $-1,247$ & 0,82 \\
\hline
\end{tabular}

